\title{
Transport and Distribution of Short-lived Climate Pollutants in the Himalaya
}

\author{
Shradda Dhungel \\ Kathmandu, Nepal
}

B. S., Southwest Minnesota State University, 2009

A Dissertation presented to the Graduate Faculty of the University of Virginia in Candidacy for the Degree of Doctor of Philosophy

Department of Environmental Sciences

University of Virginia

May, 2017 
Where I was born and where and how I have lived is unimportant. It is what I have done with where I have been that should be of interest.

-Georgia O’Keeffe 


\begin{abstract}
Major combustion sources in the Indo-Gangetic Plain (IGP) of southern Asia form persistent haze layers, also known as atmospheric brown clouds (ABC), from December through early June. ABC is a mixture of high concentrations of reactive trace gases and lightabsorbing and light-scattering particles like black carbon $(\mathrm{BC})$ and ozone $\left(\mathrm{O}_{3}\right)$ precursors. Models and satellite imagery suggest that strong wind systems within deep Himalayan valleys are major pathways by which pollutants from the IGP are transported to the higher Himalaya. However, there is a lack of observational evidence to elucidate Himalayan valleys as major pollutant pathways. To evaluate the pathway of pollutants from IGP to higher Himalaya, I measured $\mathrm{BC}, \mathrm{O}_{3}$, and associated meteorological conditions within the Kali-Gandaki Valley (KGV), Nepal, from January 2013 to July 2015. High concentrations of BC and $\mathrm{O}_{3}$ were observed during pre-monsoon (March-June) and post-monsoon (September- February) seasons. Frequent episodes of $\mathrm{BC}$ concentrations two to three fold higher than average persisted from several days to a week during non-monsoon months. Observation of increases in BC concentration and fluxes in the valley were found during pre- and post-monsoon seasons and in conjunction with widespread agricultural burning and wildfires over the IGP.

In addition to surface sources, tropospheric $\mathrm{O}_{3}$ can also be transported from the stratosphere that contributes significantly to background concentrations. Tropospheric $\mathrm{O}_{3}$ modulates the atmospheric lifetime of many atmospheric gases and like BC influences climate via direct and indirect radiative forcing. I collected ozonesonde data from Pokhara, Nepal in winter (December 2015 - January 2016) focusing on the distribution and sources of tropospheric $\mathrm{O}_{3}$ in the Himalayan region. Stratospheric influence was inferred when tropospheric air masses had potential vorticity (PV) above 1.5 PVU, relative humidity (RH) under $20 \%$ and potential temperature (theta) above $320 \mathrm{~K}$. I found that the ozonesondes that stayed south of the Himalaya measured higher $\mathrm{O}_{3}$ concentrations between 3 and $10 \mathrm{~km}$ and ozonesondes launched during high PV period were 10-20 ppbv higher between 9 and $13 \mathrm{~km}$. I also found that the topography and surface temperature induced a consistent thermal structure over the Tibetan plateau. When the jet was positioned south of the thermal gradient, high $\mathrm{O}_{3}$ concentrations were observed above $8 \mathrm{~km}$. Higher $\mathrm{O}_{3}$ concentrations were detected when the jet stream had high wind speeds (above $60 \mathrm{~ms}^{-1}$ ) and during periods of high PV given the location of the SJS was south of the thermal gradient. Layers of diffused air masses were frequently detected with PV values showing both stratospheric and tropospheric origin. This dissertation supports the hypothesis that trans-Himalayan valleys are important conduits for transport of pollutants from the IGP to TP and provides insight, for the first time, on the vertical concentrations $\mathrm{O}_{3}$ adjacent to Himalaya using MERRA-2 as a tool to understand the role of SJS and the influence of stratospheric air.
\end{abstract}




\title{
Doctoral Dissertation Committee
}

\author{
Jennie Moody (Advisor) \\ Department of Environmental Sciences, \\ University of Virginia
}

Arnico Panday

Department of Environmental Sciences,

University of Virginia

and

International Center for Integrated Mountain Development

\author{
William Keene \\ Department of Environmental Sciences, \\ University of Virginia \\ Paolo D’Odorico \\ Department of Environmental Science, Policy and Management \\ University of California, Berkeley \\ Preston Reynolds \\ Department of Medicine \\ University of Virginia
}




\section{ACKNOWLEDGEMENTS}

I feel very blessed to have come this far and that the journey has been joyous because of the presence of many wonderful people! This would not have been possible without the unstinting support from my advisor, committee, family and friends who kept me motivated and to them I owe my success. I would like to thank...

... Jennie Moody, my advisor. From all the long meetings that helped me hone my ideas to general conversations about life and career, you have been an excellent mentor. I truly admire your patience and guidance to help me reach my potential!

... William Keene. Bill, you have been instrumental in helping me evolve as a scientist. You have guided me no less than an advisor and for that dedication, I will forever be grateful. ... Arnico Panday. Thank you for taking me as your graduate student and your guidance during fieldwork in Nepal. I appreciate your friendship and look forward to working together.

... Paolo D'Odorico and Preston Reynolds, my other committee members, for their genuine support in the completion of this dissertation.

... my parents, Mithila and Keshab Dhungel, who trusted my dreams and supported my move to the US. Your love, sacrifice and trust have let me realize my goals. Fieldwork was exciting, in part because I got to see you every time I was in Nepal!

...my in-laws, Dorothy and Glenn Davis, who have always been there for me. I feel very blessed to have your love and support.

...my sister, Shruti Dhungel, for being the sweet and loving sister (especially when we are apart!). You have kept my heart close to home by including me in everyday small happenings. I looked forward to seeing you and Gunjan in Nepal during my fieldwork.

... Dr. Emily Deaver, my undergraduate advisor, who guided me and got me excited about science. Who would have thought after all those unsuccessful attempts of culturing Daphnia M. I would still be interested in the scientific process!

...Nevio Babić for his friendship and his assistance in helping me through my programming struggles, and my officemates and friends for their friendship and good company. You never made me feel I was gone for a long time even when I would be gone for over a semester each time for fieldwork.

...field and research assistants in Nepal who have helped me collect data in Nepal. Special thanks to Buddhi Lamichhane for maintaining the Jomsom station, Bhogendra Kathayat and Khadak Mohato for accompanying me to Jomsom and LoManthang, Gupta Singh Giri for helping me figure out logistics in Pokhara, and my friend, Shilpa Suwal for that one phone call which granted me ozonesonde launch permits after 2 years of governmental delays!

... my husband, Kyle Davis who has been supportive beyond measure! I cannot explain in words how your mere presence has helped me get through my academic struggles. I feel blessed to have you by my side for the rest of my life!

...the funding sources and organizations that have made this work possible: UVA, Department of Environmental Sciences, International Center for Integrated Mountain Development, National Aerospace and Space Administration (NNX12AC60G) and National Science Foundation (AGS1355551). 


\section{TABLE OF CONTENTS}

$\begin{array}{lll}\text { CHAPTER } 1 & \text { INTRODUCTION }\end{array}$

CHAPTER 2 TRANSPORT OF REGIONAL POLLUTANTS 11

THROUGH A TRANS-HIMALAYAN VALLEY

IN NEPAL

CHAPTER 3 VERTICAL DISTRIBUTION OF TROPOPSHERIC OZONE OVER THE HIMALAYAN REGION DURING WINTER

CHAPTER 4 DYNAMIC FACTORS THAT MODULATE 85 STRATOPHERIC CONTRIBUTIONS TO TROPOSPHERIC OZONE OVER THE HIMALAYAN REGION DURING WINTER 


\section{CHAPTER 1. INTRODUCTION}

\section{Short-lived Climate Pollutants}

Short-lived climate pollutants (SLCPs) that impact the climate or their precursors including black carbon, tropospheric ozone, methane, and hydrofluorocarbons are emitted to the atmosphere during the combustion of biomass (agricultural waste, biofuel, and wildfires) and fossil-fuel and from various industrial processes (e.g., production and use of refrigerants and paint). Atmospheric lifetimes range from days to a greater than one decade (black carbon: 8-10 days; ozone: $\sim 3$ weeks; methane: $\sim 12$ years; hydrofluorocarbons: $\sim 15$ years). In contrast, longer-lived climate pollutants SLCPs such as carbon dioxide have atmospheric lifetimes ranging from hundreds to thousands of years. Despite relatively much shorter atmospheric lifetimes, SLCPs are responsible for 40 to $45 \%$ of atmospheric warming, and reduction in their emissions would substantially mitigate climate change (Jacobson 2005; UNEP and WMO, 2011). Specifically, relative to a "business as usual" scenario, reductions in SLCP emissions could avoid $0.6^{\circ} \mathrm{C}$ of warming by mid-century and $1.5^{\circ} \mathrm{C}$ of warming by 2100 . Corresponding reductions in carbon dioxide emissions would avoid $0.1^{\circ} \mathrm{C}$ warming by 2050 and $1.1^{\circ} \mathrm{C}$ by 2100 (Xu et al., 2013; IGSD, 2013). SLCPs with relatively shorter lifetimes (black carbon) have relatively greater impacts on local and regional climate while those with relatively longer lifetimes (methane and hydrofluorocarbons) impact climate globally (UNEP and WMO, 2011). Pollutant particles deposited on snow surface of the Himalayas can decrease the duration of snow cover by 1 to 8 days annually and snow cover on the southern slopes of Nepalese Himalaya by 5\% (Ménégoz et al., 2014). In addition to the consequences of melting for regional water supplies, air pollutants also negatively impact human health, agriculture, and the regional economy (WHO, 2014). This dissertation investigates the cycling of black carbon and ozone in the Himalayan region (1) to resolve the processes by which regional pollutants are transported through Himalayan valleys and to quantify the associated fluxes and (2) to understand how surface and stratospheric sources modulated the vertical distribution of tropospheric ozone.

\section{Black carbon and ozone}

The effect of black carbon on climate forcing and radiative budget varies in part as a function of vertical distribution within the atmosphere. Black carbon acts as cloud condensation nuclei, 
which affects cloud formation and lifetime and can modulate precipitation patterns. Black carbon absorbs incoming solar radiation thereby cooling the surface while warming the atmosphere, which decreases relative humidity and increases stability in the atmosphere. When deposited over snow and ice, it can change the surface albedo and promote melting, which affects freshwater resources that are dependent on glacier melt.

Pollutant ozone is detrimental to human health, crop yields and ecosystems (UNEP and WMO, 2011). It also has a warming effect on the atmosphere similar to that of black carbon.

Tropospheric ozone is integral to atmospheric chemistry, acting as the primary precursor of the oxidizing hydroxyl radical, which modulates the atmospheric lifetime of many atmospheric gases (Thompson, 1992). Concentrations of tropospheric ozone vary in response to proximity to precursor sources, topography, UV radiation, temperature, relative humidity, and atmospheric transport (Monks, 2000; Ganguly and Tzanis, 2013). For example, downwind of the city of Ahmedabad, ozone mixing ratios reached 100 ppbv (Lawrence and Lelieveld, 2010). Ozone concentrations are also relatively high in biomass-burning plumes (Lelieveld and Dentener, 2000).

Most tropospheric ozone originates from either photochemical reactions involving nitrogen oxides (NOx) and volatile organic compounds or transport from the stratosphere (Crutzen et al., 1995). If mixed into the free troposphere, ozone can be transported over long distances, enhancing concentrations downwind of the sources (Fiore et al., 2002; Cooper et al., 2010). Globally, isentropic transport to the extratropics occurs in the stratosphere and in the northern hemisphere highest rate of transport occurs in the fall to spring period (Waugh et al., 1996) along with downward flux via stratosphere-troposphere exchange (STE) in the middle and high latitudes (Holton et al., 1995). Mass flux of ozone from the stratosphere to the troposphere can range from $2.3 \times 10^{17} \mathrm{~kg} \mathrm{yr}^{-1}$ (Reiter et al., 1975) to $3.8 \times 10^{17} \mathrm{~kg} \mathrm{yr}^{-1}$ (Appenzeller et al., 1996). Stratospheric air is characteristically dry and contains ozone concentrations that are typically greater than 100 ppbv (Stohl et al., 2000). During isentropic transport, stratospheric air can be injected into the troposphere often forming long streamers of ozone rich, dry air. These air parcels can be quasi-adiabatically mixed by the large-scale synoptic weather patterns and are completely diluted in tropospheric air over time (Stohl et al., 2000). Tropopause folding and the subsequent cut-off low formation have been known to inject stratospheric air at upper 
troposphere over the Alps and can be mixed to the surface via fronts and high pressure systems (Davies and Schuepbach, 1994; Bonasoni et al., 1999; Cooper et al., 2001). Cristofanelli et al., (2010) report influences of stratospheric air in surface observations at the base of Mount Everest (5079 $\mathrm{m}$ asl) but associated relationships among upper air dynamics, the subtropical westerly jet, and Himalayan topography have not been resolved.

\section{$\underline{3 \text { The Himalayan region and atmospheric brown clouds }}$}

The Himalaya range forms a $2500 \mathrm{~km}$ long and $8 \mathrm{~km}$ high complex topographic barrier separating the northern edge of the Indo-Gangetic plains from the Tibetan Plateau (Figure 1). The fertile floodplains of the Ganges, Indus and the Brahmaputra river system form the IGP, a 255 million hectare area extending from eastern Pakistan across northern India and southern Nepal to Bangladesh. Major crops including rice, wheat, corn, cotton, and sorghum are grown in the region and provide food for over 400 million people.

Anthropogenic emissions associated with expanding industry and economic growth over southern Asia contribute to rising black carbon and ozone concentrations in this region (Ramanathan and Carmichael, 2008). This increase in pollution loading over the South Asia is visible in satellite imagery as a persistent haze layer referred to as an Atmospheric Brown Cloud (ABC, Ramanathan and Crutzen, 2003). In southern Asia, ABC covers extensive areas particularly during the period of mid-November to mid-June preceding the summer monsoon season. Major combustion sources (primarily anthropogenic) including wildfires and the burning of agricultural waste, garbage, biofuel, and fossil fuels emit volatile and particulate-phase compounds to the atmosphere that contain oxidized and reduced forms of sulfur, nitrogen, and organic carbon together with elemental black carbon and other species. These emissions are intermixed and chemically interact with mechanically produced aerosols (e.g., sea salt and mineral dust) forming optically thick layers of light absorbing and light scattering particles (Menon et al., 2002) that modulate radiative transfer. Haze over the IGP often reaches heights of greater than $3 \mathrm{~km}$ above sea level via convection and advection. However, satellite imagery (Ramanathan et al., 2007), back trajectories (Lu et al., 2011), model calculations (Kopacz et al., 2011), ice core analyses (Lee et al., 2008, Kang et al., 2010), and measurements in the higher Himalaya (Bonasoni et al., 2010) strongly suggest that pollutants are efficiently transported from 
the Indo-Gangetic plains to the higher Himalaya and onto the Tibetan Plateau, especially during spring prior to the monsoon. Lüthi et al. (2015) found that synoptic circulation patterns, in combination with local weather phenomena, are associated with the transport of polluted air masses from the Indo-Gangetic plain to the Tibetan Plateau. Brun et al. (2011), use processed Moderate Resolution Imaging Spectroradiometer and Cloud-Aerosol Lidar and Infrared Pathfinder Satellite Observation images to reveal the intrusion of pollutants into the Arun Valley, Nepal. Although, that study provides evidence of pollutants transported into the Himalayan valleys, to date, no in situ observations have characterized transport through Himalayan valleys.

\section{Overview of chapters}

Chapter 2 of this dissertation evaluates the role of trans-Himalayan valleys in the transport of black carbon from the Indo-Gangetic plain to the high Himalaya. A trans-Himalayan valley refers to any Himalayan valley through which air can be directly transported from the IndoGangetic plain to the Tibetan plateau. The Kali-Gandaki valley in western Nepal was selected as a case study of the nature and magnitude of such transport. Chapter 2 provides the first observational evidence of seasonal and diurnal variability in the transport of pollutants through trans-Himalayan valleys. A 2-year record of black carbon, ozone and related meteorology in in the Kali-Gandaki valley demonstrates that strong mountain wind system throughout the year drives the transport of black carbon and ozone. These pollutants exhibit distinct diurnal and seasonal features, which are most pronounced during non-monsoon seasons. In addition, air within the Kali-Gandaki valley contains substantially higher concentrations of black carbon but lower concentrations of ozone relative to a higher elevation observatory in the region. This chapter has been submitted for publication and is currently under review. The manuscript was co-authored by Arnico Panday, Bhogendra Kathayat and Khadak Mahato.

Chapter 3 of this dissertation interprets profiles of ozone and meteorological parameters measured with sondes launched from Pokhara, Nepal, during December 2015 and January 2016, from Pokhara, Nepal, in conjunction with reanalysis data from Modern-Era Retrospective analysis for Research and Applications, version 2 (MERRA-2) to characterize stratospheric contributions to tropospheric ozone in the Himalayan region. Relationship among ozone and meteorological variables including potential vorticity, potential temperature, and relative humidity from the ozonesondes and MERRA-2 reveal significant variability in the upper 
troposphere. High potential vorticity values (1.5 to 2.0 ) at $250 \mathrm{hPa}$, low relative humidity (less than $20 \%$ ), and high potential temperature (theta, less than $310 \mathrm{~K}$ ) are used to identify significant stratospheric influences. Results show higher ozone concentrations (10 to $20 \mathrm{ppbv}$ ) between 9 and $13 \mathrm{~km}$ altitude during periods of high relative to low potential vorticity. I also compared ozone concentrations south of the Himalayan versus north based on the transport paths of the ozonesondes. Ozone concentrations were higher between 6 and $10 \mathrm{~km}$ altitude in air south of the Himalaya relative to those measured at the same altitude over the Himalaya. Possible signatures of stratospheric influence were detected as low as $7.5 \mathrm{~km}$. The manuscript is currently in preparation and is co-authored by Jennie Moody, Arnico Panday, Ryan Stauffer, Patrick Cullis, Anne Thompson, and Bryan Johnson.

Chapter 4 builds on results from chapter 3. For each ozonesonde, meridional cross-sections through Pokhara were generated to characterize the vertical and horizontal structure of wind velocity, potential vorticity, and relative humidity across the Himalaya. These cross sections were interpreted in conjuction with measured vertical profiles to evaluate the synoptic processes that modulated tropospheric ozone concentrations above $8 \mathrm{~km}$ altitude. Results indicate that upper tropospheric ozone in the Himalayan region is significantly influenced by the position of the subtropical westerly jet stream relative to the thermal gradient between the foothills south of the Himalaya and the cold Tibetan Plateau to the north. The Himalaya and Tibetan Plateau create a strong thermal gradient along the southern slope. Even though the subtropical westerly jet stream changes location, structure, and velocity, the thermal gradient contours remain a consistent feature that is sustained by the regional the topography. This thermal gradient allows isentropic transport of ozone-rich air from the stratospheres. Stratospheric influences of the ozone profiles were greatest and penetrated deeper within the troposphere when the subtropical westerly jet stream was over or south of the thermal gradient. In addition, high potential vorticity over the region and the location of the subtropical westerly jet stream south or above the theta can enhance the transport from the stratosphere into the troposphere. The manuscript is currently in preparation and is co-authored by Jennie Moody, Arnico Panday, Ryan Stauffer, Patrick Cullis, Anne Thompson, and Bryan Johnson.

Chapter 5 summarizes the key findings of the dissertation research and how this work advances current knowledge of black and ozone transport and distribution in the Himalayan region. Black 
carbon and ozone are the two most important short-lived climate pollutants with large impacts on local and regional climate versus methane and hydrofluorocarbons that have atmospheric lifetimes over a decade and have larger global impacts. Results provide the first estimates of black carbon fluxes through a trans-Himalayan valley. The wind system in the Kali-Gandaki valley had been studied previously only during September and October 1998 (Egger et al., 2000). My work revealed that this system is persistent throughout the dry season and more importantly controls the flux of pollutants. The valley funnels pollutants from the source regions to remote higher altitudes where they can modify regional climate. In addition, this work provides new insight regarding the vertical profiles of ozone south of the Himalaya and how the position of the subtropical westerly jet stream relative to the thermal gradient coupled with potential vorticity modulate influences of the stratosphere on tropospheric ozone in this region. 


\section{$\underline{\text { References }}$}

Appenzeller, C., Holton, J.R., Rosenlof, K.H., Seasonal variation of mass transport across the tropopause. Journal of Geophysical Research 101, 15071-15078, 1996.

Bonasoni, P., Evangelisti, F., Bonafe, U., Ravegnani, F., Calzolari, F., Stohl, A., Tositti, L., Tubertini, O., Colombo, T., Stratospheric ozone intrusion episodes recorded at Mt. Cimone during the VOTALP project: case studies. Atmo-spheric Environment 34, 1355-1365, 1999.

Bonasoni, P., Laj, P., Marinoni, A., Sprenger, M., Angelini, F., Ar- duini, J., Bonafe, U., Calzolari, F., Colombo, T., Decesari, S., Di Biagio, C., di Sarra, A. G., Evangelisti, F., Duchi, R., Facchini, M. C., Fuzzi, S., Gobbi, G. P., Maione, M., Panday, A., Roccato, F., Sellegri, K., Venzac, H., Verza, G. P., Villani, P., Vuillermoz, E., and Cristofanelli, P.: Atmospheric Brown Clouds in the Himalayas: first two years of continuous observations at the Nepal Climate Observatory-Pyramid (5079 m), Atmos. Chem. Phys., 10, 7515-7531, doi:10.5194/acp-10-7515-2010, 2010.

Brun, J., Shrestha, P., Barros, A., P.: Mapping aerosol intrusion in Himalayan valleys using the Moderate Resolution Imaging Spectroradiometer (MODIS) and Cloud Aerosol Lidar and Infrared Pathfinder Satellite Observation (CALIPSO), Atmos. Env., 45 (2011) 6382-6392, 2011.

Cooper, O. R., J. L. Moody, J. L., Parrish, D. D., Trainer, M., Ryerson, T. B., Holloway, J. S., Hübler, G., Fehsenfeld, F. C., Oltmans, S. J., Evans, M. J.: Trace gas signatures of the airstreams within North Atlantic cyclones: Case studies from the NARE'97 aircraft intensive, J. Geophys. Res., 106(D6), 5437-5456, doi:10.1029/2000JD900574, 2001.

Cooper, O. R.., Parrish, D. D., Stohl, A., Trainer, M., Nédélec, P., Thouret, V., Cammas, J. P., Oltmans, S. J., Johnson, B. J.. Tarasick, D., Leblanc, T., McDermid, I. S., Jaffe, D., Gao, R., Stith, J., Ryerson, T., Aikin, K., Campos, T., Weinheimer, A., Avery, M. A.: Increasing springtime ozone mixing ratios in the free troposphere over western North America, Nature, 462, 344-348, 2010.

Cristofanelli, P., Bracci, A., Sprenger, M., Marinoni, A., Bonafè, U., Calzolari, F., Duchi, R., Laj, P., Pichon, J. M., Roccato, F., Venzac, H., Vuillermoz, E., and Bonasoni, P.: Tropospheric ozone variations at the Nepal Climate ObservatoryPyramid (Himalayas, 5079 $\mathrm{m}$ a.s.1.) and influence of deep stratospheric intrusion events, Atmos. Chem. Phys., 10, 65376549, doi:10.5194/acp-10-6537-2010, 2010.

Crutzen, P., J.: Ozone in the troposphere, in composition, chemistry and climate of the atmosphere, edited by H. B. Singh, Van Norstand Reinhold, New York, 349-393, 1995. 
Davies, T. D. and E. Schuepbach, Episodes of High ozone concentrations at the Earth's surface resulting from transport down from the upper troposphere/lower stratosphere: a review and case studies, Atmosphere and Environment, 28, 1, 53-64, 1994.

Ganguly, N. D., and C. Tzanis, High surface ozone episodes at New, Delhi, India, Springer Berlin Heidelberg, 445-453, 2013.

Fiore, A. M., Jacob, D. J., Bey, I., Yantosca, R. M., Field, B. D., Fusco, A. C., and Wilkinson, J. G.: Background ozone over the United States in summer: Origin, trend, and contribution to pollution episodes, J. Geophys. Res., 107(D15), 4275, doi:10.1029/2001JD000982, 2002.

Holton, J.R., Haynes, P.H., McIntyre, E.M., Douglass, A.R., Rood, R.B., Pfister, L., Stratosphere-troposphere exchange. Reviews of Geophysics 33, 403-439, 1995.

IGSD, Primer on short-lived climate pollutants: Slowing the rate of global warming over the near term by cutting short-lived climate pollutants to complement carbon dioxide reductions for the long term Institute for Governance and Sustainable Development Switzerland, 2012.

Jacobson, M. Z., Correction to "Control of fossil-fuel particulate black carbon and organic matter, possibly the most effective method of slowing global warming” Journal of Geophysical Research 110 DOI: 10.1029/2005JD005888, 2005.

Kang, S., Xu, Y., You, Q., Flugel, W-A., Pepin, N. and Yao, T. review of Climate and cryospheric change in the Tibetan Plateau, Environ. Res. Lett. 5(1), 015101, 2010.

Kopacz, M., Mauzerall,D., L., Wang, J.,Leibensperger, E., M., Henze, D., K., and K. Singh, K.: Origin and radiative forcing of black carbon transported to the Himalayas and Tibetan Plateau, Atmos. Chem. Phys., 11, 2837-2852, 2011.

Lawrence, M. G. and Lelieveld, J.: Atmospheric pollutant outflow from southern Asia: a review, Atmos. Chem. Phys., 10, 11017-11096, doi:10.5194/acp-10-11017-2010, 2010.

Lee K, Soon DH, Shugui H, Sungmin, Xiang Q, Jaiwen R, Yapping L, Rosmann KJRR, Barbante C, Bourton CF.: Atmospheric pollution of trace elements in the remote highaltitude atmosphere in Central Asia as recorded in snow from Mt Qomolangma (Everest) of the Himalayas, Sci. Tot. Environ. 404, 171-181, 2008.

Lelieveld, J., Dentener, F. J.: What controls tropospheric ozone?, J. Geosphys. Res., 105, 35313551, 2000.

Lu, Z., Zhang, Q., and Streets, D., G.: Sulfur dioxide and primary carbonaceous aerosol emissions in China and India, 1996-2010, Atmos. Chem. Phys., 11, 9839-9864, 2011.

Luthi, Z., L., Skerlak, B., Kim, S., W., Lauer, A., Mues, A., Rupakheti, M., and Kang, S.: Atmospheric brown clouds reach the Tibetan Plateau by crossing the Himalayas, Atmos. Chem. Phys., 15, 11, 6007-6021, 2015.

Menon, S., Hansen, J., Nazarenko, L. and Yunfeng, L.: Climate Effects of Black Carbon Aerosols in Aerosols in China and India, Science, 297, 2250-2253, 2002. 
Ménégoz M et al. 2014 Snow cover sensitivity to black carbon deposition in the Himalayas: from atmospheric and ice core measurements to regional climate simulations Atmospheric Chemistry and Physics 14 doi:10.5194/acp-14-4237-2014

Monks P S 2000 A review of the observations and origins of the spring ozone maximum Atmospheric Environment 34 3545-3561.

Ramanathan, V., and Carmichael, G.: Global and regional climate changes due to black carbon, Nat. Geosci., 1(4), 221-227, 2008.

Ramanathan, V. and Crutzen, P. J.: New Directions: Atmospheric Brown "Clouds", Atmos. Env., 37, 4033-4035, 2003.

Ramanathan, V., Ramana, V., M., Roberts, G., Kim, D., Corrigan, C., Chung, C., Winker, D.: Warming trends in Asia amplified by brown cloud solar absorption, Nature, 448(2), 575-578, 2007.

Reiter, E. R: Stratospheric-tropospheric exchange processes, Review of Geophysics and Space Physics, 13(4), 459-474, 1975.

Stohl, A., Spichtinger-Rakowsky N., Bonasoni, P., Feldmann, H., Memmesheimer, M., Scheel, H.E., Trickl, T., Hubener, Ringer, S. W., Mandl, M., The influence of stratospheric intrusions on the alpine ozone ocncentrations. Atmos. Env., 34, 1323-1354, 2000.

The Economist, Pole Land: http://www.economist.com/news/science-and-technology/21577341worlds-third-largest-area-ice-about-undergo-systematic, accessed on 22 April 2017.

Thompson, A. M. The oxidizing capacity of the Earth's atmosphere: Probable past and future changes, Science, 256, 1157-1165, doi10.1126/science.256.5060.1157, 1992.

UNEP and WMO 2011 Integrated assessment of black carbon and tropospheric ozone: summary for decision makers United Nations Environment Program and World Meteorological Organization UNEP/GC/26/INF/2011.

Waugh, D.W., Seasonal variation of isentropic transport out of the tropical stratosphere. Journal of Geophysical Research 101, 4007- 4023, 1996.

WHO: Burden of disease from ambient air pollution, World Health Organization, Geneva, Switzerland, 2014.

Xu, Y., Zaelke, D., Velders, G. J. M., Ramanathan, V.:The role of HFCs in mitigating 21st century climate change Atmospheric Chemistry and Physics 13 6083-6089, 2013. 


\section{$\underline{\text { Figures }}$}

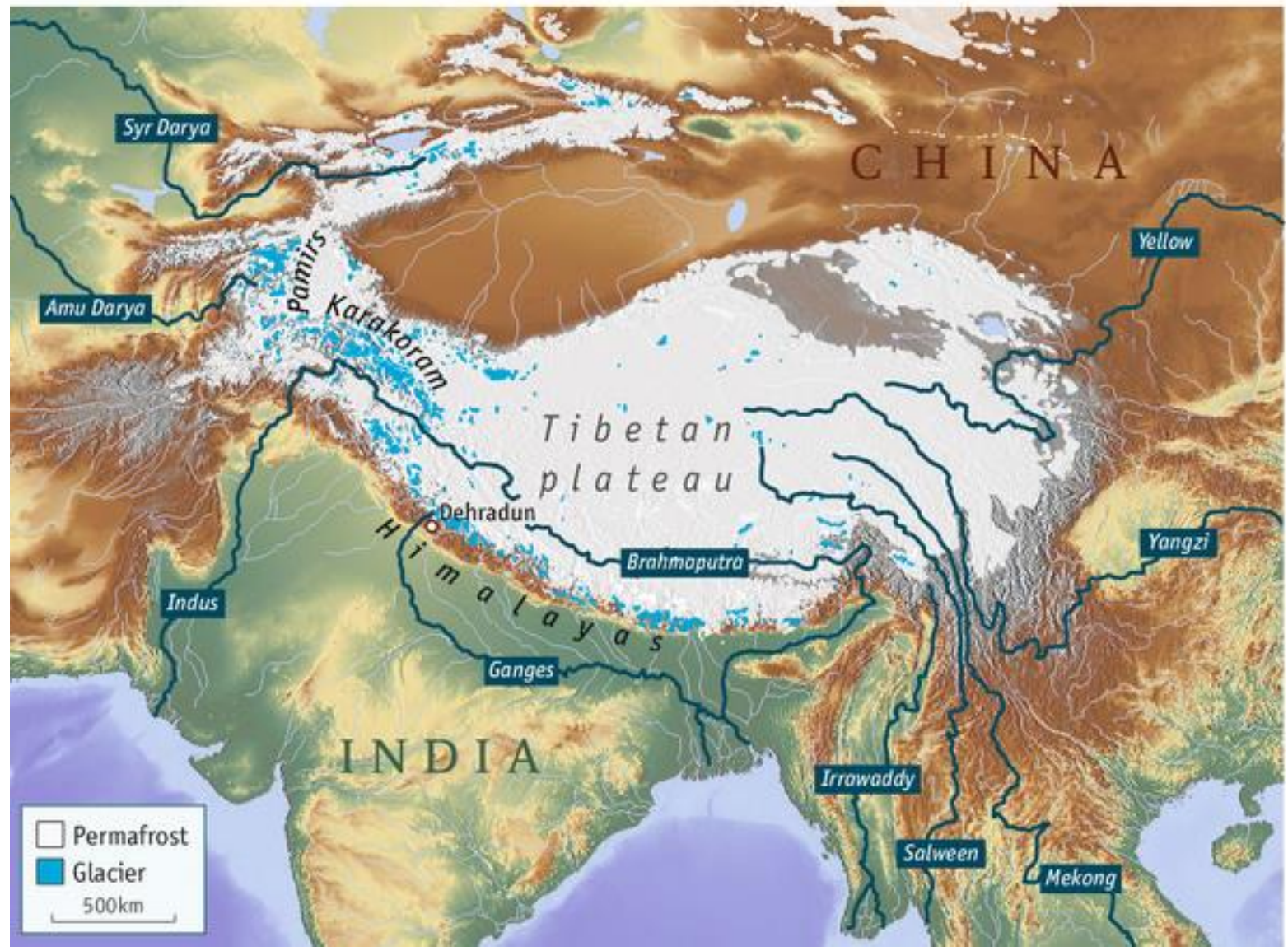

Figure 1. Map of parts of Central, South and South-east Asia showing the location of the

Himalaya and the Tibetan Plateau. The flood plains of the Indus, Ganges and Brahmaputra Rivers form the Indo-Gangetic plains (The Economist, 2017). 


\section{CHAPERT 2. TRANSPORT OF REGIONAL POLLUTANTS THROUGH A TRANS- HIMALAYAN VALLEY IN NEPAL}

\section{Abstract}

Anthropogenic emissions from the combustion of fossil fuels and biomass in Asia have increased in recent years. High concentrations of reactive trace gases and absorbing and light-scattering particles from these sources over the Indo-Gangetic Plain (IGP) of southern Asia form persistent haze layers, also known as atmospheric brown clouds, from December through early June. Models and satellite imagery suggest that strong wind systems within deep Himalayan valleys are major pathways by which pollutants from the IGP are transported to the higher Himalaya. To evaluate this pathway, we measured black carbon $(\mathrm{BC})$, ozone $\left(\mathrm{O}_{3}\right)$, and associated meteorological conditions within the Kali-Gandaki Valley (KGV), Nepal, from January 2013 to July 2015. BC and $\mathrm{O}_{3}$ varied over both diurnal and seasonal cycles. Relative to nighttime, mean $\mathrm{BC}$ and $\mathrm{O}_{3}$ concentrations within the valley were higher during daytime when the up-valley flow (average velocity of $17 \mathrm{~m} \mathrm{~s}^{-1}$ ) dominated. $\mathrm{BC}$ and $\mathrm{O}_{3}$ concentrations also varied seasonally with minima during the monsoon season (July to September). Concentrations of both species subsequently increased post monsoon and peaked during March to May. Average concentration for $\mathrm{O}_{3}$ during April, August, and November were 41.7 ppbv, 24.5 ppbv, and 29.4 ppbv, respectively, while the corresponding $\mathrm{BC}$ concentrations were $1.17 \mu \mathrm{g} \mathrm{m}^{-3}, 0.24 \mu \mathrm{g} \mathrm{m}^{-3}$, and 1.01 $\mu \mathrm{g} \mathrm{m}^{-3}$, respectively. Up-valley fluxes of $\mathrm{BC}$ fluxes were significantly greater than down-valley fluxes during each season. In addition, frequent episodes of $\mathrm{BC}$ concentrations two to three fold higher than average persisted from several days to a week during non-monsoon months. Our observations of increases in $\mathrm{BC}$ concentration and fluxes in the valley, particularly preceding the monsoon and in conjunction with widespread agricultural burning and wildfires over the IGP, support the hypothesis that trans-Himalayan valleys are important conduits for transport of pollutants from the IGP to TP. 


\section{$\underline{\text { Introduction }}$}

Persistent atmospheric haze, often referred to as Atmospheric Brown Clouds (ABC)

(Ramanathan and Crutzen, 2003), affects broad geographic regions including the Indo-Gangetic plain (IGP) in southern Asia (Ramanathan and Carmichael, 2008), eastern China (Ma et al., 2010), southeast Asia (Engling and Gelencser, 2010), sub-Saharan Africa (Piketh et al., 1999), Mexico (Vasilyev et al., 1995), and Brazil (Kaufman et al., 1998). In southern Asia, the haze covers extensive areas particularly during the period of mid-November to mid-June preceding the summer monsoon season. Major combustion sources (primarily anthropogenic) including wildfires and the burning of agricultural waste, garbage, biofuel, and fossil fuels emit volatile and particulate-phase compounds to the atmosphere that contain oxidized and reduced forms of sulfur, nitrogen, and organic carbon (OC) together with elemental (black) carbon (BC) and other species. These emissions are intermixed and chemically interact with mechanically produced aerosols (e.g., sea salt and mineral dust). Important secondary pollutants such as ozone $\left(\mathrm{O}_{3}\right)$ from photochemical reactions involving nitrogen oxides and volatile organic species are also produced. Together, this mixture of atmospheric species constitutes the ABC over South Asia (Ramanathan et al., 2005; Gustafsson et al., 2009). These optically thick layers include high concentrations of light absorbing and light scattering particles (Menon et al., 2002) that modulate radiative transfer. Light absorbing aerosols (primarily BC and crustal dust) contribute to warming of the atmosphere while light scattering aerosols (primarily S-, N-, and OC dominated particles) drive cooling at the surface. The combined effects of light absorbing and light scattering aerosols from anthropogenic sources reduce UV and visible wavelength radiation at the surface (i.e., surface forcing), increase the warming of the troposphere (i.e., atmospheric forcing) and change the net top of the atmosphere solar flux (i.e., top-of-the-atmosphere forcing) (Andreae and Crutzen, 1997; Kaufman et al., 2002, Ramanathan et al., 2005). Absorbing anthropogenic pollutants like BC significantly influence global warming, in terms of direct radiative forcing (Jacobson, 2001; Bond et al., 2013); regional influences from such pollutants close to sources are greater than those on the global scale (Ramanathan et al., 2007b).

Elevated regional concentration of aerosols weakens the anti-cyclone circulation pattern and reduces total monsoon precipitation over southern India (Ramanathan et al, 2005; Fadnavis et al., 2013) while intensifying the monsoon over the foothills of the Himalaya (Lau et al., 2006). In 
addition to warming the atmosphere, the rising concentrations of $\mathrm{BC}$ and $\mathrm{O}_{3}$ over southern Asia (e.g., Ramanathan and Carmichael, 2008) have detrimental impacts on human health (Janssen et al., 2011). $\mathrm{O}_{3}$ also compromises pulmonary function (Krupnick et. al, 1990) and is a leading pollutant causing biodiversity loss (Royal Society, 2008) and declining crop yields by directly damaging leaves (Auffhammer et al., 2006).

Haze over the IGP often reaches heights of more than $3 \mathrm{~km}$ above sea level via convection and advection but the Himalaya range forms a $2500 \mathrm{~km}$ long complex topographic barrier along the northern edge of the IGP extending more than $8 \mathrm{~km}$ high. However, satellite imagery (Ramanathan et al., 2007a), back trajectories (Lu et al., 2011), model calculations (Kopacz et al., 2011), ice core analyses (Lee et al., 2008, Kang et al., 2010), and measurements in the higher Himalaya (Bonasoni et al., 2010) strongly suggest that pollutants are efficiently transported from the IGP to the higher Himalaya and onto the Tibetan Plateau (TP), especially during spring prior to the monsoon. Absorbing aerosols warm the atmosphere at high altitudes and, when deposited onto snow and ice surfaces, decrease albedo thereby substantially increasing the rate of glacial and snow melting (Kang et al., 2010). Model simulations show that the absorbing aerosols change the surface radiative flux in the higher Himalaya and the TP by 5 to $25 \mathrm{~W} \mathrm{~m}^{-2}$ during the pre-monsoon months of April and May (Qian et al., 2011). The TP plays a vital role in regulating the regional climate due to its effect on the Asian summer monsoon (ASM) and the hydrologic cycle. The interrelated perturbations of the $\mathrm{ABC}$ on radiative transfer, air quality, the hydrologic cycle, and crop yields have important long-term implications for human health, food security, and economic activity over southern Asia.

Lüthi et al. (2015) found that synoptic circulation patterns in combination with local wind fields transport polluted air from the IGP to the TP. In addition to synoptic-scale transport over the Himalaya, several major Himalayan valleys including the Arun Valley in eastern Nepal and the Kali Gandaki Valley (KGV) in western Nepal provide topographical connections for the transport of air from the south to the TP (Fig.1). MODIS (MODerate-resolution Imaging Spectroradiometer) and CALIPSO (Cloud-Aerosol Lidar and Infrared Pathfinder Satellite Observation) imagery reveal northward slanted transport of polluted air towards higher elevations in the Arun Valley (Brun et al, 2011). However, to date, there has been little research to understand the role of mountain valleys on how air pollutants from the IGP and the Himalayan 
foothills flow through the topographic barrier of the mountain range.

Well-known flow patterns transport polluted air up valleys to higher elevations by providing a path of least resistance between tall mountains. For example, in the European Alps, prevailing wind systems in the mountain river valleys funnel polluted air from peripheral source regions to high elevations in a phenomenon known as "Alpine Pumping" (Weissmann et al., 2005). Under fair weather conditions during daytime, the upslope winds are capable of transporting significant pollutants and moisture into the free troposphere (Henne et al., 2004). Relative to air over plains, the air within the valley heats and cools more quickly (Steinacker, 1984). The resultant differences in temperature create gradients in pressure and density, which in turn drive transport of air from the plains to higher-elevations during the daytime (Reiter and Tang 1984, Whiteman and Bian, 1998; Egger et al., 2000). The Himalayan range obstructs large-scale flow, which contributes to the accumulation of high concentrations of pollutants in air over the IGP that are visible in satellite imagery especially during pre-monsoon seasons (Singh et al., 2004; Dey and Di Girolamo, 2010; Gautam et al., 2011). Despite this large barrier, measurements clearly indicated that pollutants are transported from the IGP to the Himalayan foothills (Pant et al., 2006; Dumka et al., 2008; Komppula et al., 2009; Hyvärinen et al., 2009; Ram et al., 2010; Brun et al., 2011; Gautam et al., 2011; Srivastava et al., 2012) and to higher elevations in the mountains (Bonasoni et al., 2010; Decesari et al., 2010; Marinoni et al., 2010). However, direct observational evidence of the mechanisms by which pollutants are transport via Himalayan valleys and the corresponding fluxes is lacking. Our data fills this gap by characterizing the role of the wind system within a deep Himalayan valley in transporting pollutants from the IGP to the high mountains.

\section{Measurement Sites and Methods}

\section{$\underline{\text { 2.1 Measurement Sites and Instrumentation }}$}

The KGV is located in the Dhaulagiri zone of western Nepal. Figure 1(a), shows the TP in the upper right, with the Himalayan arc, the Himalayan foothills of India, and Nepal, and the haze covered Himalayan foothills. The intrusion of haze into Himalayan valleys is clearly visible. The KGV floor changes elevation from approx. $1100 \mathrm{~m}$ to $4000 \mathrm{~m}$ asl over a horizontal distance of $90 \mathrm{~km}$ (Fig. 1(b)). Passing between the two eight thousand meter peaks of Dhaulagiri and Annapurna, it forms one of the deepest valleys in the world. The valley is a narrow gorge at the 
lower end and opens up into a wider, arid basin at the approximate mid-point (Fig. 1(b)). The maximum width of the basin is approximately one kilometer. The orientation of KGV varies from the entrance to the exit. The valley is oriented southeasterly $\left(\sim 135^{\circ}\right)$ to northwesterly $\left(\sim 315^{\circ}\right)$ at the bottom. The valley's orientation changes to southwesterly $\left(\sim 225^{\circ}\right)$ to northeasterly $\left(\sim 45^{\circ}\right)$ at the core of then turns north $\left(\sim 20^{\circ}\right)$ past the core of the valley (Fig. 1). Approximately 13,000 inhabitants in several small settlements sparsely populate the valley. Emission sources within the valley include biofuel combustion for cooking and fossil-fuel combustion by off-road vehicles. A total of 5245 vehicles have been registered in Dhaulagiri Zone since 2008, but most are based in the southern towns of Kusma, Baglung, and Beni, below $1 \mathrm{~km}$ altitude, at the lowest left corner of the map in Figure 1(b) (DOTM, 2016).

The atmospheric observatory at Jomsom (JSM_STA) $\left(28.87^{\circ} \mathrm{N}, 83.73^{\circ} \mathrm{E}, 2900 \mathrm{~m}\right.$ asl) is located within the core region of the $\mathrm{KGV}$ and was equipped with instruments to measure equivalent $\mathrm{BC}$ (hereafter referred to as $\mathrm{BC}$ ), $\mathrm{O}_{3}$, and meteorological parameters (Figure 2). With the exception of aerosol optical depth measured as part of AERONET (AErosol RObotic NETwork) (Xu et al., 2015), atmospheric characteristics at Jomsom have not been reported previously. The observatory was located on the southeast corner of a plateau jutting out from an east-facing slope about $100 \mathrm{~m}$ above the valley floor and with no major obstructions either up or down the valley. BC was measured with a Thermo Multiangle Absorption photometer (MAAP), model 5012 that incorporates a multi-angle photometer to quantify modification of radiation fields in the forward and back hemisphere of a glass-fiber filter caused by deposited particles. MAAP was operated at a flow rate of $20 \mathrm{~L} \mathrm{~min}^{-1}$ and measures BC at 1-minute frequency. Hyvärinen (2013) reports MAAP significantly underestimates BC concentrations at high aerosol loadings (greater than 9 $\mu \mathrm{g} \mathrm{m}^{-3}$ ). However, the median monthly concentrations for the duration of the measurement campaign were less than $1 \mu \mathrm{g} \mathrm{m}^{-3}$ and $90^{\text {th }}$ percentile less than $2 \mu \mathrm{g} \mathrm{m}^{-3}$ and, consequently,MAAP corrections were not applied. $\mathrm{O}_{3}$ was measured with a 2B Tech model 205 via the attenuation of ultraviolet light at $254 \mathrm{~nm}$ passing through a $15 \mathrm{~cm}$ long absorption cell fitted with quartz windows. The instrument operates at a flow rate of $1.8 \mathrm{~L} \mathrm{~min}^{-1}$. Wind speed and direction were measured by an automated weather station (AWS) installed on a ridge $900 \mathrm{~m}$ above the sampling site for $\mathrm{BC}$ and $\mathrm{O}_{3}$. 
The observatory operated from January 2013 through July 2015 but periodic power disruptions caused occasional data gaps (Supplementary Table 1). Unless otherwise noted, data reported herein correspond to periods when $\mathrm{BC}, \mathrm{O}_{3}$ and meteorological data were available simultaneously. Data were binned by season as follows: monsoon (July-September), postmonsoon (October-February) and pre-monsoon (March-June). Times correspond to Nepal's local time (LT) $(\mathrm{UTC}+5.75$ h). From March to May 2015, four additional AWSs were operated along a transect roughly 10 meters above and in the center of the valley floor where wind speeds are typically greatest: Near the entrance of the valley at Lete (LET), within the core at Marpha (MPH) and Jomsom (JSM_2), and near exit at Eklobhatti (EKL) (Fig. 1b). Power outages, instrument malfunction and a major earthquake on April 25 $5^{\text {th }}, 2015$ (and its aftershocks) limited the durations of record at all sites. However, between $1^{\text {st }}$ and $14^{\text {th }}$ May, all stations operated simultaneously and the resulting data provide information with which to evaluate diurnal variability of wind fields along the valley. $\mathrm{BC}, \mathrm{O}_{3}$ and meteorological data were averaged over 10 minute intervals.

\section{$\underline{\text { 3. Results and Discussion }}$}

\section{$\underline{3.1 \text { Seasonal variability in } \mathrm{BC} \text { and } \mathrm{O}_{3}}$}

All data generated during the measurement period were binned by month to evaluate the seasonal patterns of $\mathrm{BC}$ and $\mathrm{O}_{3}$ (Fig. 3). In addition, individual months with the most complete data coverage during the pre-monsoon (April 2013), monsoon (August 2014), and post-monsoon (November 2014) seasons were selected to evaluate aspects of temporal variability in more detail (Fig. 4). Based on median values, the highest concentrations of both species were during the months preceding the monsoon and the lowest were during months of the monsoon. We infer that the significantly lower concentrations during the monsoon reflect the influences of synoptic easterly airflow that transports cleaner marine air over the region, reduced agricultural residue burning (Sarangi et al., 2014), and more efficient removal via wet deposition (Dumka et al., 2010). $\mathrm{O}_{3}$ production is also suppressed under cloudy conditions during the monsoon (Lawrence and Lelieveld, 2010). Similar seasonal variability in BC concentration is evident across the IGP from urban to remote locations. For example, high concentrations of BC ( 1.48 to $\left.1.99 \mu \mathrm{g} \mathrm{m}^{-3}\right)$ have been reported in near-surface air across the IGP as well as in layers of the atmosphere at 900 $\mathrm{m}$ asl and $~ 1200 \mathrm{~m}$ asl during the post-monsoon over Northern India (Tripathi et al, 2005; 
2007). Sreekanth et al (2007) reported BC concentrations in Vishkhapatnam, in eastern India, to be $8.01 \mu \mathrm{g} \mathrm{m}^{-3}$ in pre-monsoon and $1.67 \mu \mathrm{g} \mathrm{m}^{-3}$ during monsoon while Ramchandran et al (2007) observed BC concentrations in Ahmedabad, western India, of $0.8 \mu \mathrm{g} \mathrm{m}^{-3}$ during the monsoon in July to $5 \mu \mathrm{g} \mathrm{m}^{-3}$ during the post monsoon in January. Similar seasonable variability has also been reported in the high Himalaya. For example, the Nepal Climate Observatory-Pyramid (NCO-P) station at the $5079 \mathrm{~m}$ asl in the Himalaya measured large seasonal variability in BC $(0.44 \pm 0.44$ $\mu \mathrm{g} \mathrm{m}^{-3}$ during pre-monsoon and $0.064 \pm 0.101 \mu \mathrm{g} \mathrm{m}^{-3}$ during monsoon season and ozone concentrations $61 \pm 9$ ppbv during pre-monsoon season and $39 \pm 10 \mathrm{ppbv}$ during monsoon (Cristofanelli et al., 2010, Marinoni et al., 2013) (Table 1). Our results indicate that seasonable variability in $\mathrm{BC}$ and $\mathrm{O}_{3}$ within the $\mathrm{KGV}$ and presumably other deep Himalayan valleys is coupled with these larger regional-scale patterns.

\section{$\underline{3.2 \text { Diurnal variability in } \mathrm{BC} \text { and } \mathrm{O}_{3}}$}

To normalize for the influence of day-to-day variability in absolute concentrations, relative diurnal variability in $\mathrm{O}_{3}$ and $\mathrm{BC}$ concentrations measured during a given month were normalized to a common scale ranging from 0 to 1 by subtracting the minimum for the month from each individual value and then dividing by the range for the month (e.g., Sander et al., 2003; Fischer et al., 2006). The data were then binned into twenty-four, 1-hour increments and plotted (Fig. 5). Based on median values during all three periods, $\mathrm{O}_{3}$ peaked during daytime and decreased to minimal levels before sunrise. However, in the pre-monsoon period, $\mathrm{O}_{3}$ peaked in the late afternoon whereas in the post-monsoon, it peaked in the early afternoon. In addition, the normalized diurnal excursions were greater during the pre- and post-monsoon periods relative to the monsoon period. In contrast, based on median values during all three periods, BC concentrations increased rapidly in the early morning, decreased during late morning, and then rose through the afternoon and early evening hours (Fig. 5). Normalized diurnal variability was somewhat greater during the post-monsoon relative to the pre-monsoon periods and lower during the monsoon period. The more skewed distributions for $\mathrm{BC}$ relative to $\mathrm{O}_{3}$ reflect infrequent periods of high $\mathrm{BC}$ concentrations during all three seasons.

Several factors contributed to differences in the diurnal variability of $\mathrm{O}_{3}$ and $\mathrm{BC}$. These include diurnal variability in emissions of $\mathrm{BC}$ versus $\mathrm{O}_{3}$ precursors and/or production in source regions followed by regional transport, diurnal variability in the photochemical chemical production and 
destruction of $\mathrm{O}_{3}$, and contributions of $\mathrm{O}_{3}$ from non-combustion sources. $\mathrm{O}_{3}$ is produced photochemically and is lost via deposition to surfaces and chemical reactions. In contrast, $\mathrm{BC}$ is a primary emission product of combustion that may originate from both local and distant sources. The early morning peak during all three seasons suggests probable contributions from the local combustion of biofuels for cooking and heating, which are most prevalent during early morning. The secondary peak in the afternoon and early evening occur when the local anthropogenic sources are at minimum in the KGV.

\section{$\underline{3.3 \text { Evolution of the local wind system in the KGV }}$}

Wind roses based on all data illustrate the temporal evolution of up- and down-valley flows at JSM_2 for each season (Fig. 6). Up-valley flows are southwesterly and dominant during daytime with peak velocities above $15 \mathrm{~m} \mathrm{~s}^{-1}$ between about 0900 LT to $1800 \mathrm{LT}$. Wind velocities decreased substantially after 1800 LT, with variable wind direction until midnight then northeasterly winds are common during pre- and post-monsoon seasons (Fig. 6a and 6c)). The wind pattern during monsoon was strongly influenced by the monsoon anticyclone, consistent with wind direction measured in other Himalayan valleys (Ueno et al., 2008; Bonasoni et al., 2010) (Fig. 6b) Although wind velocities at JSM_2 varied somewhat over the year, similar diurnal patterns during non-monsoon months evolved seasonally as a function of sunrise and sunset (Fig. 6). As discussed below, this alternating pattern in wind velocity and direction from strong up-valley flow during daytime to weak down-valley flow at night resulted in a net transport of pollutants up the valley.

Theodolite observations at different locations along the KGV in 1998 show shifts of less than $45^{\circ}$ in wind direction and less than $2 \mathrm{~m} \mathrm{~s}^{-1}$ in wind speed in the lower $1000 \mathrm{~m}$ above the surface during daytime (Egger et.al 2000). Based on the average daytime wind speed, the valley can be partitioned into three regions: the entrance, core, and exit (average wind speeds range from 5 to $10 \mathrm{~m} \mathrm{~s}^{-1}, 8$ to $18 \mathrm{~m} \mathrm{~s}^{-1}$, and less than $5 \mathrm{~m} \mathrm{~s}^{-1}$, respectively) (Egger et al 2000). The strongest winds within the core region are most prevalent in the lower 1000 to $1500 \mathrm{~m}$ of the boundary layer

within the valley (Egger et al, 2000; Zängl et al., 2000, Egger et al., 2002). Our measurements at the four AWS stations on the valley floor illustrate the evolution of surface wind velocities along the length of the KGV (Supplementary Figure 1). In addition, comparison of measurements at JSM_1 between $1^{\text {st }}$ and $14^{\text {th }}$ May 2015 with those for the longer-term record JSM_2 during same 
period (Fig. 6 and Supplementary Figure 1) provide information regarding vertical variability. Velocities at the higher elevation site of JSM_2 were about $5 \mathrm{~m} \mathrm{~s}^{-1}$ greater than those near the valley floor during the day and $3 \mathrm{~m} \mathrm{~s}^{-1}$ greater at night but with both exhibited similar diurnal cycles. Wind speed along the valley floor peaked within the core of the valley at MPH, JSM_1 and JSM_2 and were lower in the entrance (LET) and exit (EKL) regions (Supplementary Figure 1). The duration of strong wind speeds within the valley during daytime is consistent with the hypothesis that local wind patterns are modulated by pressure gradients created by differential heating of the arid valley floor relative to the mouth (Egger et al., 2000).

\section{$\underline{\text { 3.3.1 Local winds as drivers of } \mathrm{BC} \text { and } \mathrm{O}_{3} \text { in the } \mathrm{KGV}}$}

Figure 4 shows the time series of $\mathrm{BC}$ and $\mathrm{O}_{3}$ during individual months of each season (April/premonsoon, August/monsoon, November/post-monsoon). For pre-monsoon, BC concentrations peaked at 0700 LST (Fig. 4) when wind velocities were relatively low (Fig. 4). During the post monsoon, BC peakedabout an hour later. During all seasons, BC concentrations decreased over the rest of the morning as wind speeds increase (Fig. 5). Dilution of local emissions associated from increasing wind speed likely contributed to decreasing $\mathrm{BC}$ concentration during late morning. Thereafter, concentrations increased over the afternoon and early night, reaching secondary peaks near midnight LST during the pre-monsoon and several hours earlier during other periods (Fig. 4 and 5). Distinct morning and afternoon peaks were evident during the postmonsoon season when the up-valley wind speeds are relatively lower than during the premonsoon season (Fig. 5 and 6). This bimodal diurnal distribution of BC concentration at Jomsom is similar to that at other high elevation sites during non-monsoonal periods (Hindman et al., 2002; Hegde et al., 2007; Bonasoni et al., 2010). In contrast, $\mathrm{O}_{3}$ mixing ratios exhibited a distinct minimum in the early morning, increased during the morning, peaked in the early afternoon well before that of BC, and decreased overnight (Fig. 5).

Results for all days for which complete BC and meteorological data were available over entire 24-hour periods were binned by season and partitioned into subsets of up-valley (southwesterly) flow defined as between $35^{\circ}$ and $55^{\circ}$ down-valley (northeasterly) flow defined as between $215^{\circ}$ and $235^{\circ}$. Percentage distributions of up-valley and down-valley BC concentrations, fluxes, and net daily fluxes per unit cross section are depicted in Figure 7 and summarized in Table 1. The statistical significance of differences between up-valley and down-valley flow conditions during 
different seasons were evaluated using the non-parametric Kruskal Wallis and Mann-Whitney tests. The distribution of BC concentrations between up-valley and down-valley flow are statistically significant for all seasons (Figure 7a). However, because wind velocities were relatively higher during up-valley daytime flow and the durations of up-valley were modestly longer than those of down-valley flow, the corresponding up-valley fluxes of BC during daytime were significantly greater than down-valley fluxes during all seasons (Fig. 7b). These results suggest an oscillatory movement of polluted air within the valley. Differences between upvalley versus down-valley fluxes yielded significant net positive up-valley fluxes of BC during all seasons (Fig. 7c). Because heating would have driven growth of the boundary layer and thus greater ventilation and dilution of pollutants during daytime relative to night, we infer that the calculated differences between up-valley versus down-valley fluxes correspond to lower limits for net BC fluxes.

Positive up-valley fluxes are consistent with an "alpine pumping" mechanism in the Himalayan valleys and support the hypothesis that these valleys are important pathways for pollution transport. If we assume that (1) the polluted boundary layer within the valley at Jomsom is $800 \mathrm{~m}$ deep (i.e., the approximate elevational difference between the two AWS sites at Jomsom), (2) $\mathrm{BC}$ within the polluted boundary layer is well mixed, and (3) wind velocities do not vary significantly with altitude through the polluted layer, the mass flux BC through a vertical plane across the valley can be estimated. Because some BC is almost certainly transported above 800 m elevation, this approach yields a conservative estimate. The long lifetime of particulate BC against deposition (several days to a week or more) coupled with turbulent flow within the valley supports the assumption that BC is well mixed. As noted previously, wind velocities measured at JSM_1 (2800 m) and JSM_2 (3700 m) were similar suggesting minimal variability through the lower $800 \mathrm{~m}$ depth of the valley. Extrapolation of the net daily BC flux per unit area to the cross-sectional plane of the valley at Jomsom $\left(1.62 \mathrm{~km}^{2}\right)$ yields net daily fluxes of BC through the valley during the pre-monsoon season of $1.2 \mathrm{~kg} \mathrm{day}^{-1}$ (based on the average daily net flux) and $0.83 \mathrm{~kg} \mathrm{day}^{-1}$ (based on the median daily net daily flux) (Table 1). A significant up-valley flux exists even during monsoon season with $0.36 \mathrm{~kg} \mathrm{day}^{-1}$ (average) and $0.23 \mathrm{~kg} \mathrm{day}^{-1}$ (median) of total BC flux across the cross-sectional plane. Such estimates provide useful semi-quantitative constraints on mass fluxes of BC from the IGP to the high Himalaya through deep valleys and, more generally, on the regional cycling of BC over southern Asia. 


\section{$\underline{3.4 \text { Evidence of regional transport episodes in valley concentration }}$}

In addition to the diurnal and seasonal variability driven by local winds (described above), we also observed anomalous periods of several days during which concentrations of both $\mathrm{BC}$ and $\mathrm{O}_{3}$ were significantly greater than the $90^{\text {th }}$ percentile for corresponding annual averages (Supplementary Table 3). These extended periods of high $\mathrm{BC}$ and $\mathrm{O}_{3}$ suggest large-scale transport during regional pollution events from the IGP to the foothills in conjunction with local valley winds (Fig. 8). Most of the episodes were associated with satellite imagery of enhanced emission over the IGP including persistent haze, agricultural and biomass burning in Punjab regions of India and Pakistan, and forest fires in the foothills of the Himalaya in northern India or southern Nepal (Supplementary Table 3). The 90 ${ }^{\text {th }}$ percentile for each year 2013, 2014 and 2015 were $1.53 \mu \mathrm{g} \mathrm{m}^{-3}, 1.60 \mu \mathrm{g} \mathrm{m}^{-3}$ and $1.47 \mu \mathrm{g} \mathrm{m}^{-3}$ respectively. The year 2015 only included January through July data.

A total of 31 regional episodes were identified from January 2013 till July 2015. The wind speeds and directions at Jomsom during these transport episodes exhibited diurnal variability similar to those during other periods (Fig. 8 [II]). For each episode, Hybrid Single-Particle Lagrangian Integrated Trajectories (HYSPLIT) starting at altitudes of $300 \mathrm{~m}, 500 \mathrm{~m}$ and $1000 \mathrm{~m}$ from the mouth of the valley were run back in time for 72 hours (Stein et al., 2015). The back trajectories indicate air-mass transport from the above source regions during these episodes (Fig. 9).

During the regional transport period in November 2014, the average daily BC concentration was $1.29 \mu \mathrm{g} \mathrm{m}^{-3}$ which is greater than the $75^{\text {th }}$ percentile $\left(0.88 \mu \mathrm{g} \mathrm{m}^{-3}\right)$ of the $\mathrm{BC}$ concentration throughout measurement duration. The maximum daily concentration during the episode was $3.04 \mu \mathrm{g} \mathrm{m}^{-3}$. However, the corresponding average $\mathrm{O}_{3}$ was $(28.1 \mathrm{ppbv})$ was slightly less than the average (29.5 ppbv) for the entire data set (Figure 8 [Ia]). The diurnal wind pattern in the KGV during this episode was similar to that during the rest of the year (Figure 8 [IIa]). The MODIS fire data couples with HYSPLIT back trajectories indicate extensive haze and fire events within the fetch regions for air transported to the mouth of the valley during this period (Figure 9). These results indicate that the transport of $\mathrm{BC}$ emitted from agricultural burning and wildfires during this period probably contributed to the high concentrations measured within the KGV. 
Another example of a regional transport episode occurred in May 2014, during which BC concentration was $1.77 \mu \mathrm{g} \mathrm{m}^{-3}$ (Figure $8[\mathrm{Ib}]$ ). It was above the $90^{\text {th }}$ percentile $\left(1.49 \mu \mathrm{g} \mathrm{m}^{-3}\right.$ ) for entire measurement period while the average $\mathrm{O}_{3}$ concentration (49.7 ppbv) wasslightly less than the $90^{\text {th }}$ percentile (52.9 $\mathrm{ppbv}$ ) for the entire period. The wind pattern in the KGV exhibited diurnal flow patterns but with a somewhat longer period (about 2 hours) of up-valley flow compared to pattern A (Fig. 8 [IIb]). During this period, MODIS imagery and HYSPLIT back trajectories revealed widespread burning within the fetch region of the Himalayan foothills and the Punjab of India (Figure 9).

In May 2013, the average concentrations of $\mathrm{BC}\left(2.09 \mu \mathrm{g} \mathrm{m}^{-3}\right)$ and $\mathrm{O}_{3}(57.5 \mathrm{ppbv})$ were greater than the corresponding $90^{\text {th }}$ percentiles for both (Fig. 8 [Ic]). Diurnal wind patterns were similar to those of pattern B with relatively longer durations of up-valley flow (Fig. 8 [IIc]). MODIS and HYSPLIT back trajectories revealed extensive agricultural burning in the fetch region over the Punjab of India and the southern plains of Nepal (Figure 9). Again, these results indicate that high concentration of combustion products emitted from regional burning were transported to the valley mouths via synoptic circulation patterns and then efficiently funneled through the KGV to higher elevations via wind system within the valley.

\subsection{Pollution in the Higher Himalaya}

Average BC concentrations in European cities including Barcelona, Lugano and London typically range from about 1.7 to $1.9 \mathrm{\mu g} \mathrm{m}^{-3}$ (Reche et al., 2011). National Ambient Air Quality Standards (NAAQS) for the United States for $\mathrm{O}_{3}$ is $70 \mathrm{ppbv}$ (8-hour maximum average). During regional transport episodes, $\mathrm{BC}$ and $\mathrm{O}_{3}$ levels at the remote Jomsom observatory occasionally exceeded the above levels for both $\mathrm{BC}$ and $\mathrm{O}_{3}$. In addition, seasonal patterns in $\mathrm{BC}$ and $\mathrm{O}_{3}$ at JSM-STA were similar to those at NCO-P CNR (Bonasoni et al., 2010) with highest concentrations during the pre-monsoon season and lowest during the monsoon. However, relative differences between $\mathrm{BC}$ and $\mathrm{O}_{3}$ at the two locations varied seasonally (Table 2). During the pre-monsoon, BC concentrations at JSM_STA were a factor of two higher than those at NCO-P CNR whereas, during the post-monsoon season, BC concentrations at JSM_STA were a factor of five higher. In contrast, $\mathrm{O}_{3}$ concentration at JSM_STA were systematically lower than those at NCO-P CNR during both the pre- and post-monsoon seasons. NCO-P CNR is located at a higher elevation $(5079 \mathrm{~m})$ relative to Jomsom $(2800 \mathrm{~m})$ and is impacted by frequent intrusions 
of $\mathrm{O}_{3}$-rich stratospheric air (Cristofanelli et al., 2010), which we infer contributed to the consistently higher $\mathrm{O}_{3}$ concentrations at NCO-P CNR relative to those at JSM_STA.

\section{Conclusion}

Results of this study supports the hypothesis that trans-Himalayan valleys are important pathways by which air pollutants are transported from the IGP to the higher Himalaya and TP. We found that:

- Concentrations of $\mathrm{BC}$ and $\mathrm{O}_{3}$ in the $\mathrm{KGV}$ exhibited systematic diurnal and seasonal variability. The diurnal pattern of $\mathrm{BC}$ concentrations during the pre- and post-monsoon seasons were modulated by the oscillating nature of up-valley and down-valley flows. Concentrations of $\mathrm{BC}$ during the pre-monsoon season were higher than those during post-monsoon.

- The morning and afternoon peaks in BC during the post monsoon season was more pronounced than those of pre-monsoon season likely due to the relatively lower wind speeds and associated low dilution during post-monsoon.

- $\quad$ Significant positive up-valley fluxes of BC were measured during all seasons.

- During episodes of regional pollution over the IGP, relatively higher concentrations of $\mathrm{BC}$ and $\mathrm{O}_{3}$ were also measured in the $\mathrm{KGV}$.

- Relative to those at NCO-P CNR, a higher-elevation site in the Himalaya, BC concentrations at JSM-STA were higher during all seasons whereas the corresponding $\mathrm{O}_{3}$ concentrations were lower.

Further studies are needed to understand the vertical and horizontal distribution of particulate matter and $\mathrm{O}_{3}$ in the Himalayan region, and their impact on the radiative budget, the ASM and climate. Investigations using sondes, LiDar and air-borne measurements could help characterize the stratification of the vertical air masses.

\section{$\underline{\text { Acknowledgments }}$}

We would like to acknowledge our field assistant in Nepal, Buddhi Lamichhane who helped us in various stages of the study, as well as the logistic and administrative support and internet at 
the Jomsom station provided by Nepal Wireless. Financial support was provided by the National Aeronautics and Space Administration NNX12AC60G, and additional field support was provided by ICIMOD's Atmosphere Initiative. The authors are very thankful for comments from William Keene and Jennie Moody. 


\section{$\underline{\text { References }}$}

Andreae, M. O. and Crutzen, P. J.: Atmospheric Aerosols: Biogeochemical Sources and Role in Atmospheric Chemistry, Science, 1052-1058, 1997.

Auffhammer, M., Ramanathan, V. and Vincent, J. R.: Integrated model shows that atmospheric brown clouds and greenhouse gases have reduced rice harvests in India, PNAS 10.1073/pnas.0609584104, 2006.

Bonasoni, P., Laj, P., Marinoni, A., Sprenger, M., Angelini, F., Ar- duini, J., Bonafe, U., Calzolari, F., Colombo, T., Decesari, S., Di Biagio, C., di Sarra, A. G., Evangelisti, F., Duchi, R., Facchini, M. C., Fuzzi, S., Gobbi, G. P., Maione, M., Panday, A., Roccato, F., Sellegri, K., Venzac, H., Verza, G. P., Villani, P., Vuillermoz, E., and Cristofanelli, P.: Atmospheric Brown Clouds in the Himalayas: first two years of continuous observations at the Nepal Climate Observatory-Pyramid (5079 m), Atmos. Chem. Phys., 10, 7515-7531, doi:10.5194/acp-10-7515-2010, 2010.

Bond, T., Doherty, S., Fahey, D., Forster, P., Berntsen, T., DeAngelo, B., Flanner, M., Ghan, S., Kärcher, B., and Koch, D.: Bounding the role of black carbon in the climate system: A scientific assessment, J. Geophys. Res.-Atmos., 118, 5380-5552, doi:10.1002/jgrd.50171, 2013.

Brun, J., Shrestha, P., Barros, A., P.: Mapping aerosol intrusion in Himalayan valleys using the Moderate Resolution Imaging Spectroradiometer (MODIS) and Cloud Aerosol Lidar and Infrared Pathfinder Satellite Observation (CALIPSO), Atmos. Env., 45 (2011) 6382-6392, 2011.

Cristofanelli, P., Bracci, A., Sprenger, M., Marinoni, A., Bonafè, U., Calzolari, F., Duchi, R., Laj, P., Pichon, J. M., Roccato, F., Venzac, H., Vuillermoz, E., and Bonasoni, P.: Tropospheric ozone variations at the Nepal Climate ObservatoryPyramid (Himalayas, 5079 $\mathrm{m}$ a.s.1.) and influence of deep stratospheric intrusion events, Atmos. Chem. Phys., 10, 65376549, doi:10.5194/acp-10-6537-2010, 2010.

Dey, S., and Di Girolamo, L.: A climatology of aerosol optical and microphysical properties over the Indian subcontinent from 9 yr (2000-2008) of Multiangle Imaging Spectroradiometer 
(MISR) data, J. Geophys. Res., 115, D15204, doi:10.1029/2009JD013395, 2010.

Decesari, S., Facchini, M.C., Carbone, C., Giulianelli, L., Rinaldi, M., Finessi, E., Fuzzi, S., Marinoni, A., Cristofanelli, P., Duchi, R., Bonasoni, P., Vuillermoz, E., Cozic, J., Jaffrezo, J., L., Laj, P.: Chemical composition of $\mathrm{PM}_{10}$ and $\mathrm{PM}_{1}$ at the high-altitude Himalayan station Nepal Climate Observatory-Pyramid (NCO-P) (5079 m a.s.1.), Atmos. Chem. Phys., 10: 4583-4596, 2010.

DOTM-Vehicle data zonal wise till 2072 baishakh, Government of Nepal, Department of Transportation Management (http://www.dotm.gov.np/uploads/files/Vehicle-data-zonalwise-till-2072-baishakh.pdf) accessed March 26 ${ }^{\text {th }}, 2016$.

Dumka, U., C., Krishna Moorthy, K., Satheesh, S., K., Sagar, R., Pant, P.: Short-period modulations in aerosol optical depths over the central Himalayas: role of mesoscale processes, J. Appl. Meteor. Climatol., doi: 10.1175/2007JAMC1638.1, 2008.

Dumka, U., C., Moorthy, K., K., Kumar, R., Hegde, P., Sagar, R., Pant, P., Singh, N., Babu, S.: Characteristics of aerosol black carbon mass concentration over the high altitude location in the central Himalayas from multi-year observations. Atmos. Res., 96, 510-521 2010.

Egger, J., Bajracharya, S., Egger, U., Heinrich, R., Reuder, J., Shakya, P., Wendt, H., and Wirth, V.: Diurnal winds in the Himalayan Kali Gandaki valley. Part I: observations, Mon. Weather Rev., 128, 1106-1122, 2000.

Egger, J., Bajracharya, S., Egger, U., Heinrich, R., Kolb, P., Lammlein, S., Mech, M., Reuder, J., Schaper, W., Shakya, P., Schween, J. and Wendt, H.: Diurnal winds in the Himalayan Kali Gandaki valley. Part III:remotely piloted aircraft soundings, Mon. Weather Rev., 130, 20422058, 2002.

Engling, G., and Galencser, A.: Atmospheric brown clouds: from local air pollution to climate change, Elements, 6, 223-228, 2010.

Fadnavis, S., Semeniuk, K., Pozzoli, L., Schultz, M. G., Ghude, S. D., Das, S., and Kakatkar, R.: Transport of aerosols into the UTLS and their impact on the Asian monsoon region as seen in a global model simulation, Atmos. Chem. Phys., 13, 8771-8786, 2013. 
Fischer, E., Pszenny, A., Keene, W., Maben, J., Smith, A., Stohl, A., Talbot R.: Nitric acid phase partitioning and cycling in the New England coastal atmosphere, J. Geophys. Res., 111, D23S09, doi:10.1029/2006JD007328, 2006.

Flanner, M. G., Zender, C. S. , Hess, P. G., Mahowald, N. M., Painter, T. H., Ramanathan, V., Rasch , P. J.: Springtime warming and reduced snow cover from carbonaceous particles, Atmos. Chem. Phys., 9 (7), 2481- 2497, doi: 10.5194/acp-9-2481-2009, 2009.

Gautam, R., Hsu, N., C., Tsay, S., C., Lau, K., M., Holben, B., Bell, S., Smirnov, A., Li, C., Hansell, R., Ji, Q., S. Payra, S., Aryal, D., Kayastha, R., K. M. Kim, K., M. : Accumulation of aerosols over the Indo-Gangetic plains and southern slopes of the Himalayas: distribution, properties and radiative effects during the 2009 pre-monsoon season, Atmos. Chem. Phys., $11,12841-12863,2011$

Gustafsson, O., Kruså, M., Zencak, Z., Sheesley, R., J., Granat, L., Engström,E., Praveen, P., S., Rao, P., S., P., Leck, C., Rodhe, H.: Brown Clouds over South Asia: Biomass or Fossil Fuel Combustion?, Science, 323, 495-498, 2009.

Hegde P., Pant, P., Naja, M., Dumka, U. C., and Sagar, R.: South Asian dust episode in June 2006: Aerosol observations in the central Himalayas, Geophys. Res. Lett., 34, L23802, doi:10.1029/2007GL030692, 2007.

Henne, S., Furger, M., Nyeki, S., Steinbacher, M., Neininger, B., de Wekker, S.F.J, Dommen, J., Spichtinger, N., A. Stohl, A. and Prevót A. S. H.: Quantification of topographic venting of boundary layer air to the free troposphere, Atmos. Chem. Phys., 4, 497-509, 2004.

Hindman, E. E. and Upadhyay, B. P.: Air pollution transport in the Himalayas of Nepal and Tibet during the 1995-1996 dry season, Atmos. Environ., 36, 727-739, 2002.

Hyvärinen, A., P., Lihavainen, H., Komppula, M., Sharma, V., P., Kerminen, V., M., Panwar, T., S., Viisanen, Y.: Continuous measurements of optical properties of atmospheric aerosols in Mukteshwar, Northern India, J. Geophys. Res., 114: D08207, doi: 10.1029/2008JD011489, 2009.

Hyvarinen, A., -P., Vakkari, V., Laakso, L., R. K. Hooda, R., K., Sharma, V., P., Panwar, T., S., Beukes, J., P., van Zyl, P., G., M. Josipovic, M., Garland, R. M., Andreae, M. O., Poschl, U., 
Petzold, A. : Correction for a measurement artifact of the Multi-Angle Absorption Photometer (MAAP) at high black carbon mass concentration levels, Atmos. Meas. Tech., 6, 81-90, 2013

Jacobson, M., Z.: Strong radiative heating due to the mixing state of black carbon in atmospheric aerosols, Nature, 409, 695-697, 2001.

Janssen, Nicole A. H., Hoek, G., Simic-Lawson, M., Fischer, P., van Bree, L., Brink, H., Keuken, M., Atkinson, R. W., Anderson, H. R., Brunekreef, B., and Cassee, F. R.: Black carbon as an additional indicator of the adverse health effects of airborne particles compared with $\mathrm{PM}_{10}$ and $\mathrm{PM}_{2.5}$, Environ. health persp. 119 (12), 1691-1698, 2011.

Kang, S., Xu, Y., You, Q., Flugel, W-A., Pepin, N. and Yao, T. review of Climate and cryospheric change in the Tibetan Plateau, Environ. Res. Lett. 5(1), 015101, 2010.

Kaufman, Y. J., Tanré, D., and Boucher, O.: A satellite view of aerosols in the climate system, Nature, 419, 215-223, 2002.

Koch, D., Schulz, M., Kinne, S., McNaughton, C., Spackman, J.R., Balkanski, Y., Bauer, S., Berntsen, T., Bond, T.C., Boucher, O., Chin, M., Clarke, A., De Luca, N., Dentener, F., Diehl, T., Dubovik, O., Easter, R., Farey, D.W., Feichter, J., Fillmore, D., Freitag, S., Ghan, S., Ginoux, P., Gong, S., Horowitz, L., Iversen, T., Kirkevåg, A., Klimont, Z., Kondo, Y., Krol, M., Liu, X., Miller, R., Montanaro, V., Moteki, N., Myhre, G., Penner, J.E., Perlwitz, J., Pitari, G., Reddy, S., Sahu, L., Sakamoto, H., Schuster, G., Schwarz, J.P., Seland Ø, Stier P., Takegawa, N., Takemura, T., Textor, C., van Aardenne, J.A., Zhao, Y.: Evaluation of black carbon esti- mations in global aerosol models. Atmospheric Chemistry and Physics 9, 9001e9026.Komppula, M., Lihavainen, H., A.-P. Hyvärinen,A., -P., Kerminen, V., -M., Panwar, T., S., Sharma, V., P., Viisanen, Y.: Physical properties of aerosol particles at a Himalayan background site in India, J. Geophys. Res., 112, doi:10.1029/2008JD011007, 2009.

Kopacz, M., Mauzerall,D., L., Wang, J.,Leibensperger, E., M., Henze, D., K., and K. Singh, K.:

Origin and radiative forcing of black carbon transported to the Himalayas and Tibetan Plateau, Atmos. Chem. Phys., 11, 2837-2852, 2011. 


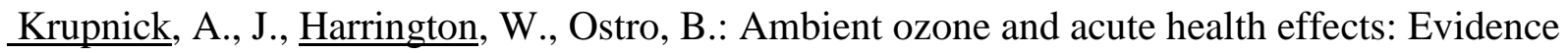
from daily data, J. Environ. Econ. Manag., 18(1), 1-18, 1990.

Lau, K., M., Kim, M., K., Kim, K., M.: Asian summer monsoon anomalies induced by aerosol direct forcing: The role of the Tibetan Plateau, Climate Dynamics, 26, 855-864, 2006.

Lawrence, M. G. and Lelieveld, J.: Atmospheric pollutant outflow from southern Asia: a review, Atmos. Chem. Phys., 10, 11017-11096, doi:10.5194/acp-10-11017-2010, 2010.

Lee K, Soon DH, Shugui H, Sungmin, Xiang Q, Jaiwen R, Yapping L, Rosmann KJRR, Barbante C, Bourton CF.: Atmospheric pollution of trace elements in the remote highaltitude atmosphere in Central Asia as recorded in snow from Mt Qomolangma (Everest) of the Himalayas, Sci. Tot. Environ. 404, 171-181, 2008.

Lu, Z., Zhang, Q., and Streets, D., G.: Sulfur dioxide and primary carbonaceous aerosol emissions in China and India, 1996-2010, Atmos. Chem. Phys., 11, 9839-9864, 2011.

Luthi, Z., L., Skerlak, B., Kim, S., W., Lauer, A., Mues, A., Rupakheti, M., and Kang, S.: Atmospheric brown clouds reach the Tibetan Plateau by crossing the Himalayas, Atmos. Chem. Phys., 15, 11, 6007-6021, 2015.

Ma, J., Chen, Y., Wang, W., Yan, P., Liu, H.,Yang, S., Hu, Z., and Lelieveld, J.: Strong air pollution causes widespread haze-clouds over China, J. Geophys. Res., 115, D18204, 2010.

Marinoni, A., Cristofanelli, P., Laj, P., Duchi., R., Calzolari, F., Decesari, S., Sellegri, K., Vuillermoz, E., Verza, P., Villani, P., Bonasoni, P. Aerosol mass and black carbon concentrations, a two year record at NCO-P (5079 m, Southern Himalayas), Atmos., Chem. Phys., 10, 8551-8562, 2010.

Marinoni, A., Cristofanelli, P., Laj, P., Duchi., R., Putero, D., Calzolari, F., Landi., T., C., Vuillermoz, E., Maione, M., Bonasoni, P.: High black carbon and ozone concentrations during pollution transport in the Himalayas: Five years of continuous observations at NCO-P global GAW station, J. Environ. Sci., 25(8) 1618-1625, 2013.

Menon, S., Hansen, J., Nazarenko, L. and Yunfeng, L.: Climate Effects of Black Carbon Aerosols in Aerosols in China and India, Science, 297, 2250-2253, 2002. 
Pant, P., Hegde, P., Dumka, U., C., Sagar, R., Satheesh, S., K., Krishna Moorthy, K., Saha, A., Srivastava, M., K.: Aerosol characteristics at high-altitude location in central Himalayas: optical properties and radiatuve forcing, J. Geophys. Res., doi:10.1029/2005JD006768, 2006.

Piketh, S. J., Annegarn, H., J., and Tyson, P., D.: Lower tropospheric aerosol loadings over South Africa: The relative contribution of aeolian dust, industrial emissions, and biomass burning, J. Geophys. Res., 104(D1), 1597-1607, 1999.

Qian, Y., Flanner, M. G., Leung, L. R., and Wang, W.: Sensitivity studies on the impacts of Tibetan Plateau snowpack pollution on the Asian hydrological cycle and monsoon climate, At- mos. Chem. Phys., 11, 1929-1948, doi:10.5194/acp-11-1929- 2011, 2011.

Raatikainen, T., Hyvärinen, A.-P., Hatakka, J., Panwar, T., S., Hooda, R., K., Sharma, V., P., Lihavainen, H.: The effect of boundary layer dynamics on aerosol properties at the IndoGangetic plains and at the foothills of the Himalayas, Atmos. Env., 89, 548-555, 2014.

Raatikainen, T., Brus, D., Hooda, R., K., Hyvärinen, A.-P., Asmi, E., Sharma, V., P., Arola, A., Lihavainen, H.: Size-selected black carbon mass distributions and mixing state in polluted and clean environments of northern India, Atmos. Chem. Phys. 17, 371-383, 2017.

Ram, K., Sarin, M., M. and Hegde, P.: Long-term record of aerosol optical properties and chemical composition from a high-altitude site (Manora Peak) in central Himalaya, Atmos. Chem. Phys., 10: 11791-11803, 2010.

Ramanathan, V., and Carmichael, G.: Global and regional climate changes due to black carbon, Nat. Geosci., 1(4), 221-227, 2008.

Ramanathan, V., Chung, C., Kim, D., Bettge, T., Buja, L., Kiehl, J., T., Washington, W., M., Fu, Q., Sikka, D., R., and Wild, M.: Atmospheric brown clouds: Impacts on South Asian climate and hydrological cycle, PNAS, 102(15), 5326-5333, 2005.

Ramanathan, V. and Crutzen, P. J.: New Directions: Atmospheric Brown "Clouds”, Atmos. Env., 37, 4033-4035, 2003.

Ramanathan, V., Ramana, V., M., Roberts, G., Kim, D., Corrigan, C., Chung, C., Winker, D.: 
Warming trends in Asia amplified by brown cloud solar absorption, Nature, 448(2), 575-578, 2007a.

Ramanathan, V., Li, F., Ramana, M.V., Praveen, P.S., Kim, D., Corrigan, C.E., Nguyen, H., Stone, E.A., Schauer, J.J., Carmichael, G.R., Adhikary, B., Yoon, S.C.: Atmospheric Brown Clouds: Hemispherical and Regional Variations in Long-Range Transport, Absorption, and Radiative Forcing, J. Geophys. Res., 112, D22821, $2007 \mathrm{~b}$.

Reche, C., Querol, X., Alastuey, A., Viana, M., Pey, J., Moreno, T., Rodríguez, S., González, Y., Fernández-Camacho, R., De La Campa, A. M, Sálnchez,De La Rosa, J., Dall'Osto, M., Prév̂t, A. S H, Hueglin, C., Harrison, R. M., Quincey, P.: New considerations for PM, Black Carbon and particle number concentration for air quality monitoring across different European cities, Atmos. Chem. Phys., 11, 6207-6227, 2011.

Reddy, M.S. and Venkataraman, C.: Inventory of Aerosol and Sulphur Dioxide Emissions from India: II - Biomass Combustion, Atmos. Envir., 36 (4), 699-712, 2002.

Reiter, E. R., and Tang, M.: Plateau effects on diurnal circulation patterns. Mon. Wea. Rev., 112, 638-651, 1984.

Sander, R., Keene, W. C., Pszenny, A. A. P., Arimoto, R., Ayers, G. P., Baboukas, V., Chainey, J. M. Crutzen, P. J., Duce, R. A., Hönninger, G., Huebert, B. J., Maenhaut, W., Mihalopoulos, N., Turekian, V. C., van Dingenen, R.: Inorganic bromine in the marine boundary layer: A critical review, Atmos. Chem. Phys, 3, 1301-1336, 2003.

Sarangi, T., Naja, M., Ohja, N., Kumar, R., Lal, S., Venkataramani, S., Kumar, A., Sagar, R., Chandola, H., C.: First simultaneous measurements of ozone, $\mathrm{CO}$ and $\mathrm{NO}_{\mathrm{y}}$ at a high-altitude regional representative site in the central Himalayas, JGR, 119(3), 1592-1611, 2014).

Singh R. P., Dey, S., Tripathi, S. N., Tare, V., and Holben, B.: Variability of aerosol parameters over Kanpur, northern India, J. Geophys. Res., 109, D23206, doi:10.1029/2004JD004966, 2004.

Sreekanth, V., Niranjan, K., Madhavan, B. L.: Radiative forcing of Black Carbon over Eastern India, Geophys. Res. Lett., 34(L17818), doi: 10.1029/2007GL030377, 2007. 
Srivastava, A., K., Singh, S., Pant, P. and Dumka, U., C. : Characteristics of black carbon over Delhi and Manora peak - A comparative study, Atmos. Sci. Lett.,13: 223-230, 2012.

Stein, A.F., Draxler, R.R, Rolph, G.D., Stunder, B.J.B., Cohen, M.D., and Ngan, F., (2015). NOAA's HYSPLIT atmospheric transport and dispersion modeling system, Bull. Amer. Meteor. Soc., 96, 2059-2077, http://dx.doi.org/10.1175/BAMS-D-14-00110.1, 2015.

Steinacker, R.: Area-height distribution of a valley and its relation to the valley wind, Beitr. Phys. Atmos., 57, 64-71, 1984.

Streets, D. G., Bond, T. C., Carmichael, G. R., Fernandes, S. D., Fu, Q., He, D., Klimont, Z., Nelson, S. M., Tsai, N. Y., Wang, M. Q., Woo, J. H., and Yarber, K. F.: An inventory of gaseous and primary aerosol emissions in Asia in the year 2000, J. Geophys. Res.-Atmos., 108, 8809, doi:10.1029/2002JD003093, 2003.

The Royal Society, 2008. Ground-level ozone in the 21st century: future trends, impacts and policy implications. Science policy report 15/08. The Royal Society, London.

Tripathi, S. N., Dey, S., Tare, V., Satheesh, S. K.: Aerosol black carbon radiative forcing at an industrial city in northern India. Geophys. Res. Lett. 32 (L08802). doi:10.1029/2005GL022515, 2005.

Tripathi, S. N., Srivastava, A. K., Dey, S., Satheesh, S. K., Moorthy, K. K.: The vertical profile of atmospheric heating rate of black carbon aerosols at Kanpur in northern India. Atmos. Env.41: 6909-6915, 2007.

Ueno, K., Toyotsu, K., Bertolani, L., and Tartari, G.: Stepwise onset of Monsoon Weather Observed in the Nepal Himalayas, Mon. Weather Rev., 136(7), 2507-2522, 2008.

Vasilyev, O. B., Contreras, A., L., Velazquez, A., M., Fabi, R., P., Ivlev, L., S., Kovalenko, A., P., Vasilyev, A., V., Jukov, V., M., and Welch, R., M.: Spectral optical properties of the polluted atmosphere of Mexico City (spring-summer 1992), J. Geophys. Res., 100(D12), 26027-26044, 1995.

Weissmann, M., Braun, A. F. J., Gantner, A., L., Mayr, A., G., J.,Rahm, A., S., Reitebuch, A., O. :The Alpine Mountain-Plain Circulation: Airborne Doppler Lidar Measurements and Numerical Simulations, Mon. Weather Rev., 133,(11), 3095-3109, 2005. 
Whiteman, C. D., and Bian X.: Use of radar profiler data to investigate large-scale thermally driven flows into the Rocky Mountains, Proc. Fourth Int. Symp. on Tropospheric Profiling: Needs and Technologies, Snowmass, CO, 1998.

Xu, C., Ma, Y. M., You, C., and Zhu, Z. K.: The regional distribution characteristics of aerosol optical depth over the Tibetan Plateau, Atmos. Chem. Phys., 15, 12065-12078, 2015.

Yasunari, T. J., Bonasoni, P., Laj, P., Fujita, K., Vuillermoz, E., Marinoni, A., Cristofanelli, P., Duchi, R., Tartari, G., and Lau, K.-M.: Estimated impact of black carbon deposition during pre- monsoon season from Nepal Climate Observatory - Pyramid data and snow albedo changes over Himalayan glaciers, Atmos. Chem. Phys., 10, 6603-6615, doi:10.5194/acp-106603-2010, 2010.

Zangl, G., Egger, J., and Wirth, V.: Diurnal Winds in the Himalayan Kali Gandaki Valley. Part II: Modeling, Mon. Weather Rev., 129, 1062-1080, 2000. 


\section{$\underline{\text { Figures }}$}

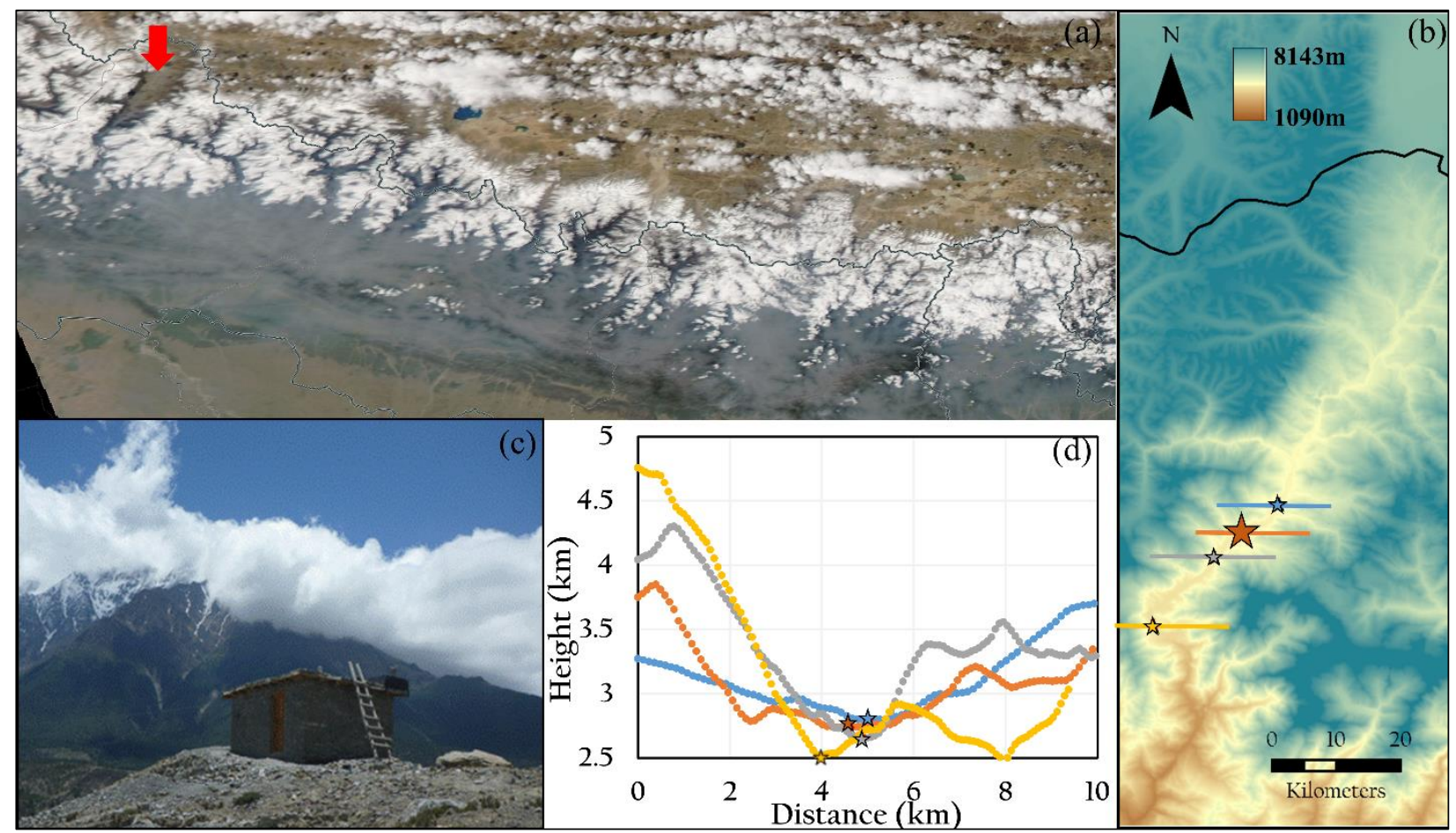

Figure 1. (a) NASA Worldview image from November 4, 2014 depicting thick haze intruding the Himalayan foothills with red arrow over the KGV. (b) Expanded scale of the KGV showing locations of LET near the entrance of the valley (yellow star); MPH in the core region (gray star); the JSM_STA sampling station for BC and $\mathrm{O}_{3}$ and the two associated AWS sites (JSM_1 and JSM_2) in the core region (orange star); and EKL near the exit (blue star). (c) The atmospheric observatory at Jomsom (JSM_STA). (d) Cross-sectional elevation profile at the indicated locations. 


\begin{tabular}{|c|c|c|c|c|}
\hline & Station & Location & Elevation & Instrument(parameters measured) \\
\hline 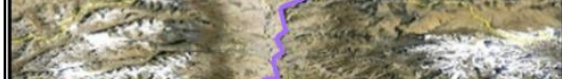 & \multirow{2}{*}{ JSM_STA } & \multirow{2}{*}{$\begin{array}{l}28.87 \mathrm{~N} \\
83.73 \mathrm{E}\end{array}$} & \multirow{2}{*}{$2850 \mathrm{~m}$} & $\begin{array}{l}\text { Thermo BC MAAP-Model } 5012 \\
\text { (Black carbon) }\end{array}$ \\
\hline & & & & $\begin{array}{l}\text { 2B Tech Ozone instrument-Model } 205 \\
\text { (Ozone) }\end{array}$ \\
\hline & JSM_AWS_l & $\begin{array}{l}28.87 \mathrm{~N} \\
83.73 \mathrm{E}\end{array}$ & $2800 \mathrm{~m}$ & $\begin{array}{l}\text { DAVIS-Model Vantage Pro } 2 \\
\text { (WD, WS, T, RH, DP) }\end{array}$ \\
\hline & JSM_AWS_2 & $\begin{array}{c}28.87 \mathrm{~N} \\
83.73 \mathrm{E} \\
\end{array}$ & $3700 \mathrm{~m}$ & $\begin{array}{c}\text { NexSens-Model Vaisala WXT520 } \\
\text { (WD, WS, T, RH, DP, Precip, Solar rad) }\end{array}$ \\
\hline & LET_AWS & $\begin{array}{c}28.93 \mathrm{~N} \\
83.35 \mathrm{E}\end{array}$ & $2500 \mathrm{~m}$ & $\begin{array}{c}\text { Nexsens-ModelVaisala WXT520 } \\
\text { (WD, WS, T, RH, DP, Precip, Solar rad) }\end{array}$ \\
\hline & MPH_AWS & $\begin{array}{c}28.44 \mathrm{~N} \\
83.41 \mathrm{E}\end{array}$ & $2665 \mathrm{~m}$ & $\begin{array}{l}\text { HOBO-Model AWS U-30 } \\
\text { (WD, WS, T) }\end{array}$ \\
\hline & EKL_AWS & $\begin{array}{l}28.49 \mathrm{~N} \\
83.46 \mathrm{E} \\
\end{array}$ & $2804 \mathrm{~m}$ & $\begin{array}{c}\text { NexSens-ModelVaisala WXT520 } \\
\text { (WD, WS, T, RH, DP, Precip, Solar rad) }\end{array}$ \\
\hline
\end{tabular}

Figure 2. The valley floor of KGV is shown in purple along with details pertaining to

measurement sites and the installed instruments. 


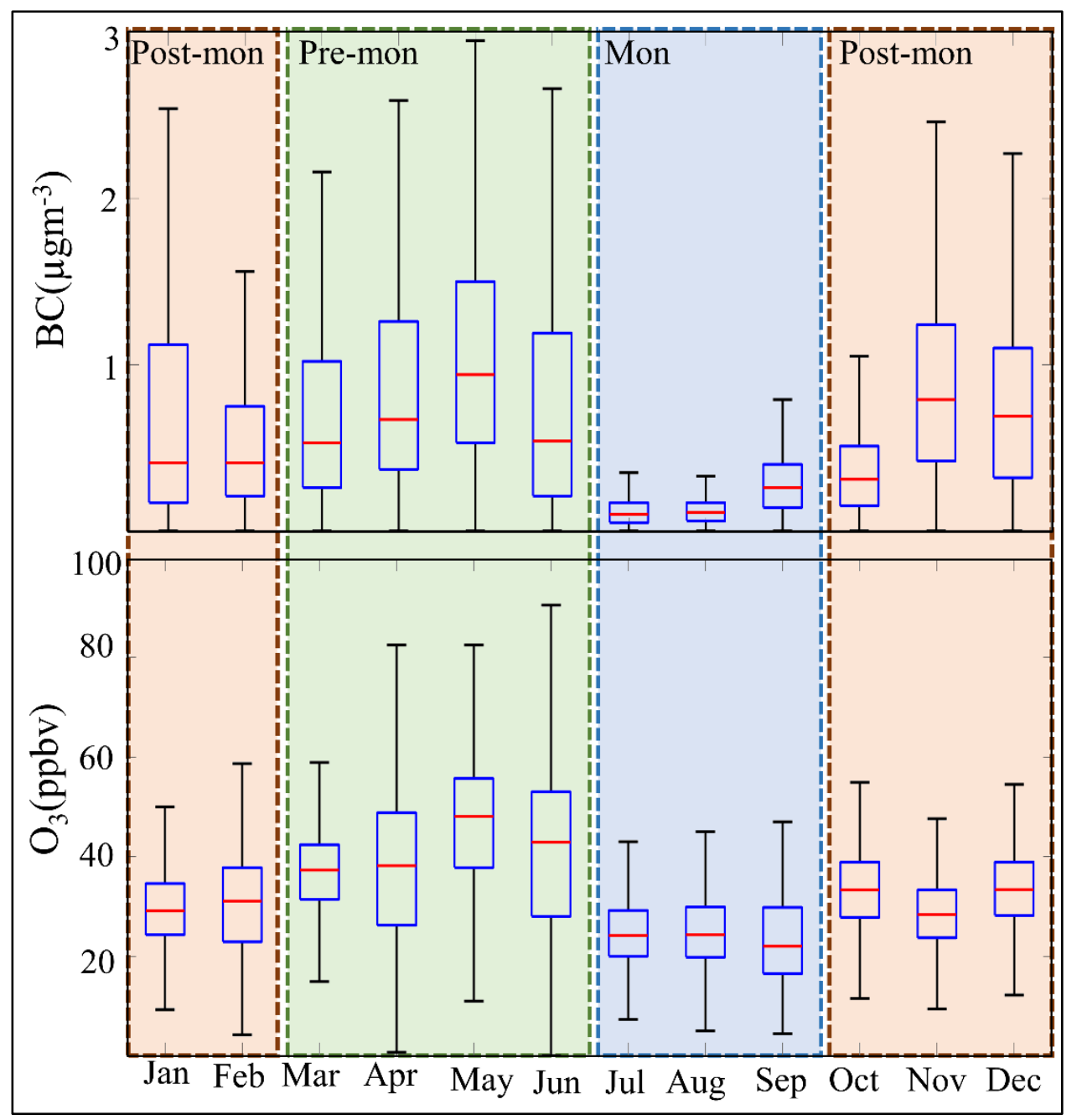

Figure 3. Box and whisker plots depicting the $90^{\text {th }}, 75^{\text {th }}, 50^{\text {th }}, 25^{\text {th }}$, and $10^{\text {th }}$ percentiles for monthly of BC (upper panel) and $\mathrm{O}_{3}$ (lower panel) between January 2013 and August 2015 at JSM_STA. Orange shaded areas indicate the post-monsoon season (Post-mon), green shaded area indicates the pre-monsoon (Pre-mon) and blue are indicates the monsoon (Mon) season. 


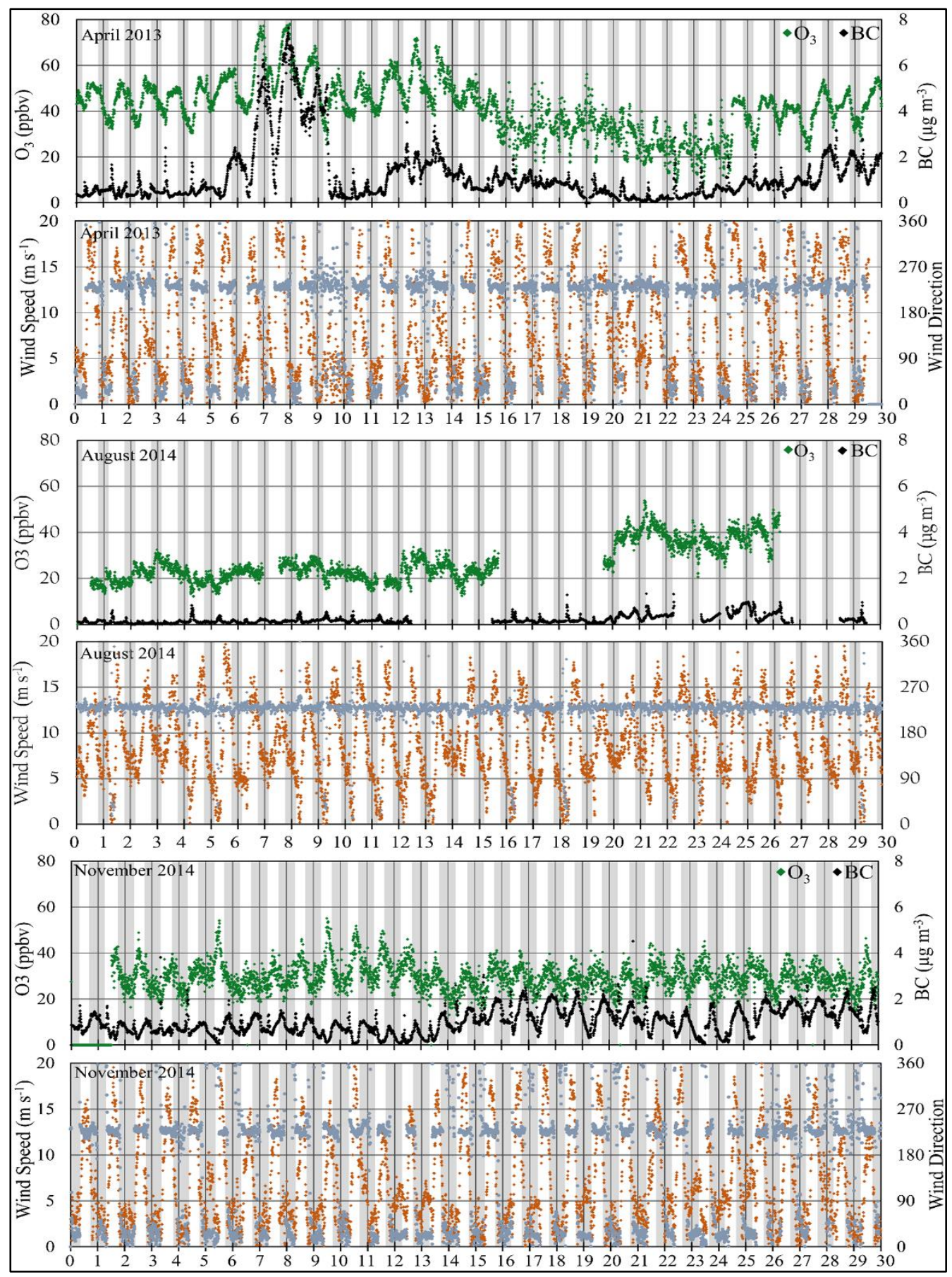

Figure 4. Variation in $\mathrm{O}_{3}, \mathrm{BC}$, and associated wind speed and direction at JSM_STA during (a) April 2013 (pre-monsoon), (b) August 2014 (monsoon), and (c) November 2014 (post monsoon). The grey shaded area denotes night. 
Table 1. Total daily and seasonal BC flux across the cross-sectional plane at JSM_1.

\begin{tabular}{|c|c|c|c|c|}
\hline \multirow[t]{2}{*}{ Season } & \multicolumn{2}{|c|}{ Daily flux $\left[\mathrm{Kg} \mathrm{day}^{-1}\right]$} & \multicolumn{2}{|c|}{ Seasonal flux $\left[\mathrm{Kg}\right.$ month $\left.^{-1}\right]$} \\
\hline & Mean & Median & Mean & Median \\
\hline Pre-monsoon & 1.2 & 0.83 & 36.6 & 25.3 \\
\hline Monsoon & 0.36 & 0.23 & 6.73 & 4.28 \\
\hline Post-monsoon & 0.60 & 0.44 & 11.2 & 8.15 \\
\hline
\end{tabular}



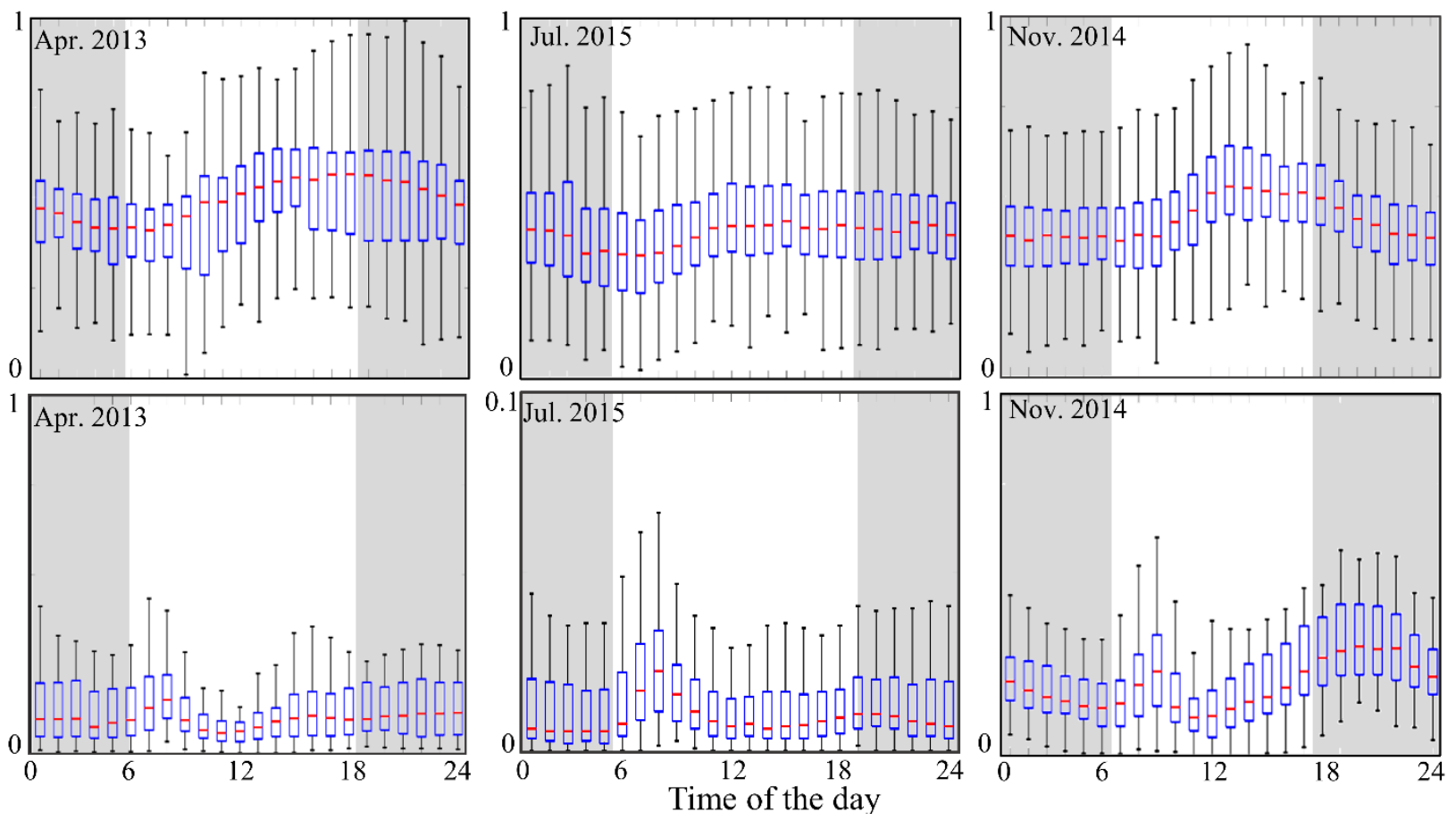

Figure 5. Box and whisker plots depicting the $90^{\text {th }}, 75^{\text {th }}, 50^{\text {th }}, 25^{\text {th }}$, and $10^{\text {th }}$ percentiles for normalized diel variability in $\mathrm{O}_{3}$ (upper panels) and BC (lower panels) at JSM_STA during April 2013 (pre-monsoon), July 2015 (monsoon), and November 2014 (post-monsoon). Scale for July 2015 is from 0 to 0.1 . 


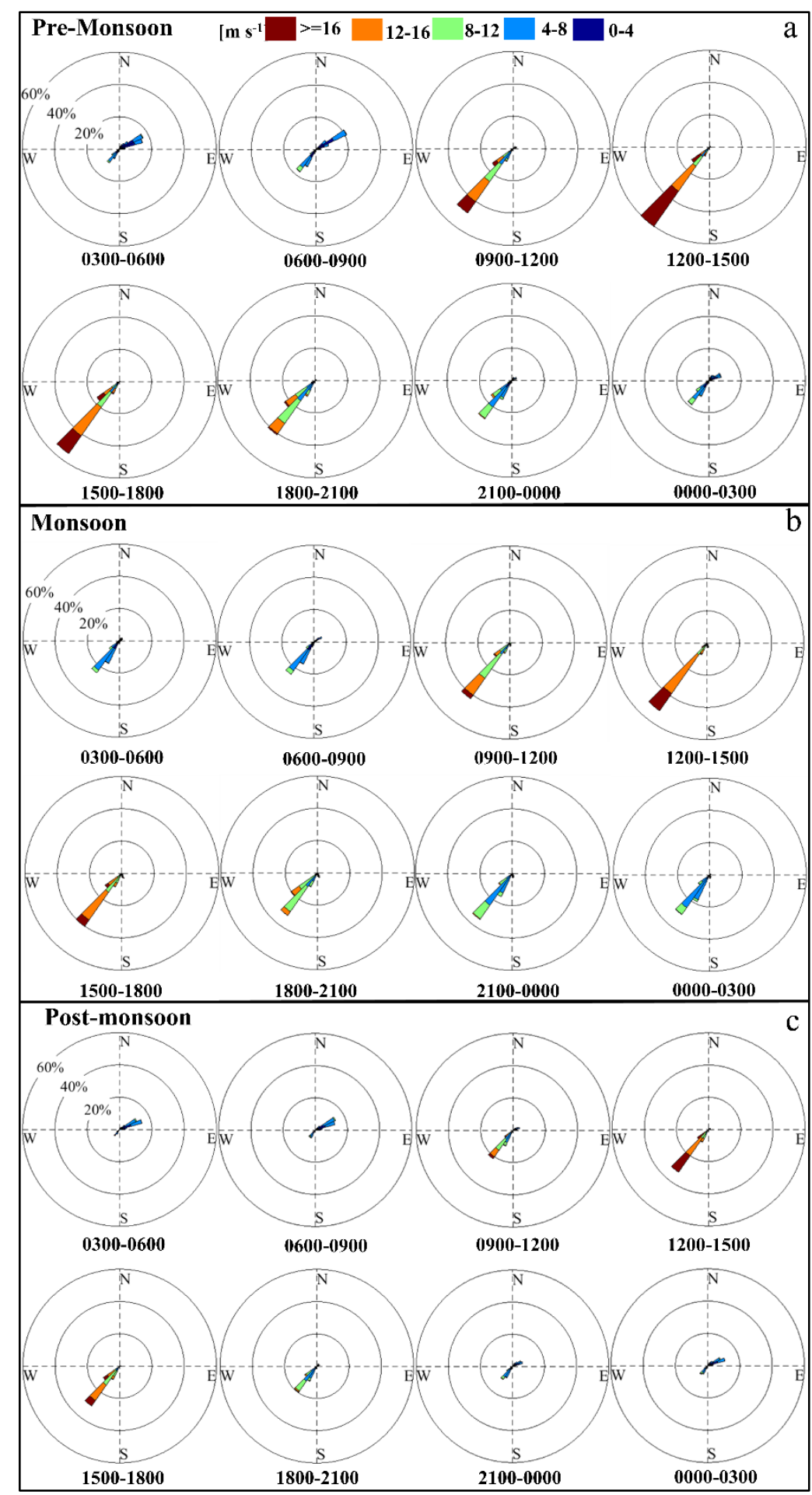

Figure 6. (a) Wind rose for each season binned into 3-hour increments depiciting diurnal evolution in wind speed and direction at JSM_2. 


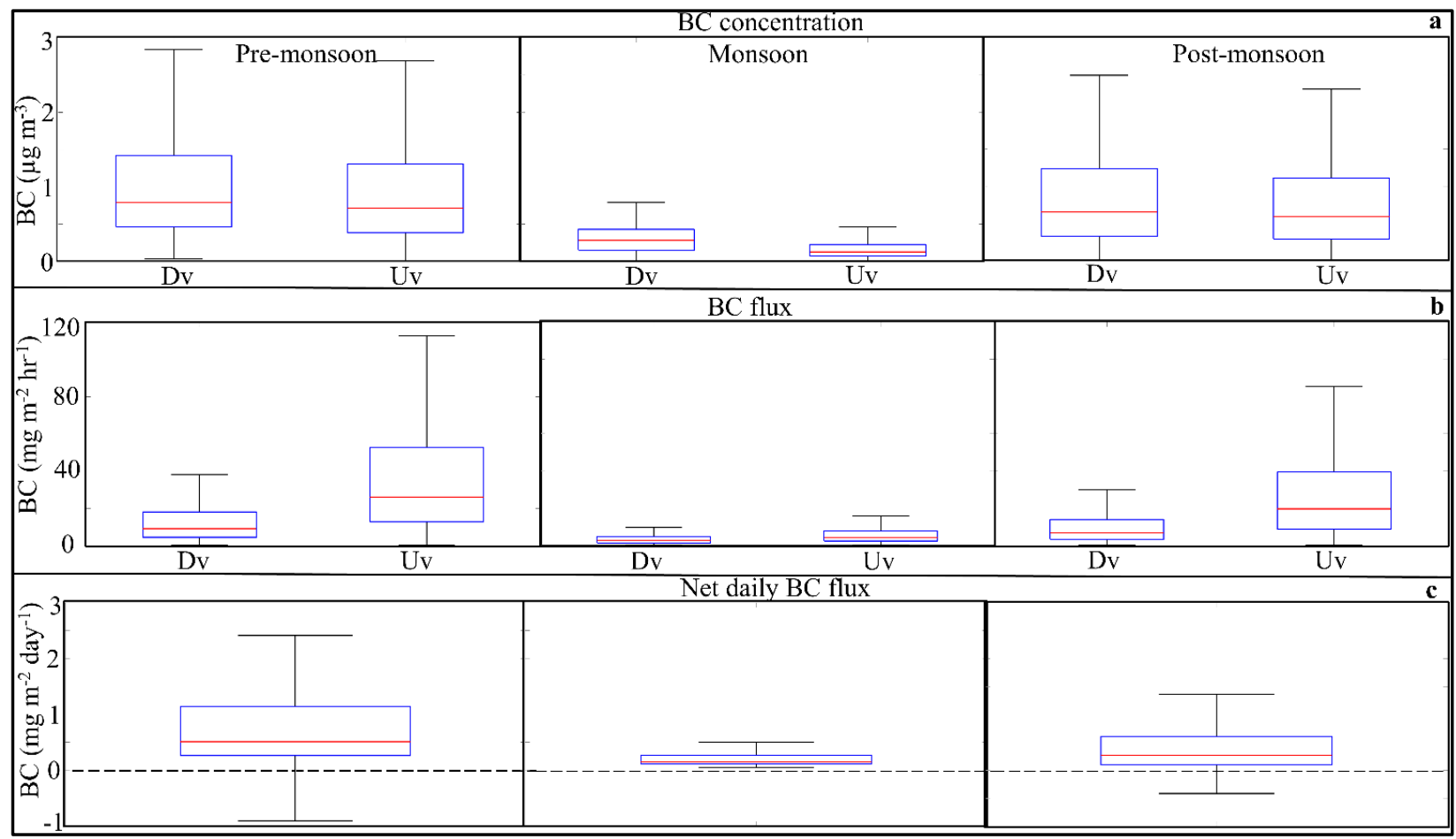

Figure 7. (a) BC concentration distribution with down-valley (Dv) and up-valley (Uv) flows in Jomsom, (b) calculated Dv and Uv flux for each season, (c) Net daily flux per season. The dotted line is panel c marks $0 \mathrm{mg} \mathrm{m}^{-2} \mathrm{day}^{-1}$. 


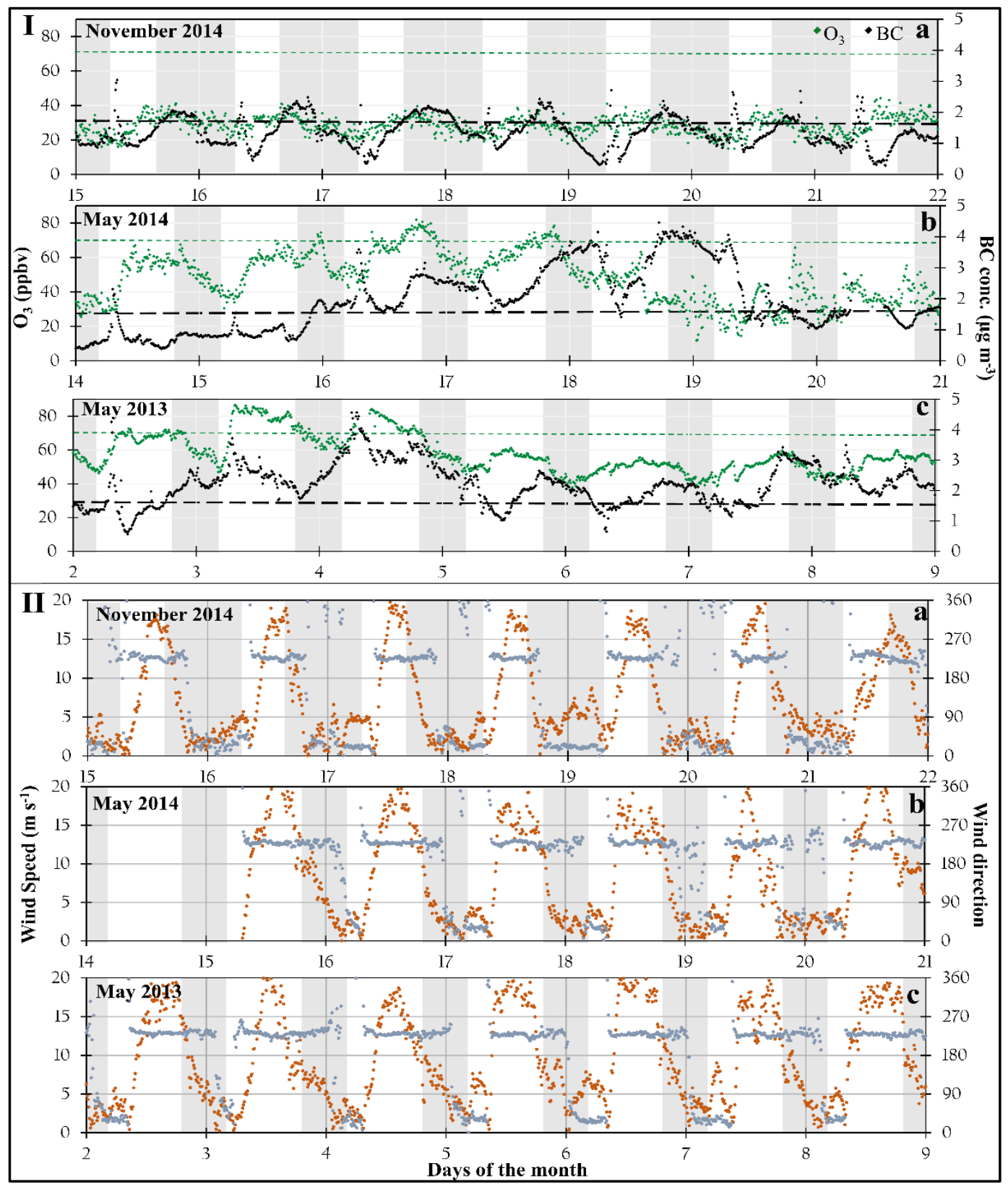

Figure 8. (I) Examples of extended periods with relatively high $\mathrm{BC}$ and $\mathrm{O}_{3}$ concentrations at JSM_STA during November 2014 (Pattern A) and May 2014 (Pattern B) and May 2013 (Pattern C). The solid black and greeen lines depict two-year averages for $\mathrm{BC}$ and $\mathrm{O}_{3}$, respectively. (II) Corresponding wind direction and wind speed during the high $\mathrm{BC}$ and $\mathrm{O}_{3}$ episodes. 
Table 2. Seasonal variability in mean $\mathrm{BC}$ and $\mathrm{O}_{3}$ concentrations ( \pm 1 standard deviation) at NCOP CNR and JSM_1.

\begin{tabular}{|c|c|c|c|c|c|}
\hline Sites & Altitude (m) & Co-ordinates & Season & $\mathrm{BC}\left(\mu \mathrm{g} \mathrm{m}^{-3}\right)$ & $\mathrm{O}_{3}(\mathrm{ppb})$ \\
\hline \multirow{3}{*}{$\begin{array}{l}\text { NCO-P } \\
\text { Nepal Climate Observatory } \\
\text { Pyramid } \\
\text { (Bonasoni et al., 2010) }\end{array}$} & 5079 & $27.95^{\circ} \mathrm{N}, 86.81^{\circ} \mathrm{E}$ & Pre-monsoon & $0.32( \pm 0.34)$ & $60.9( \pm 8.4)$ \\
\hline & & & Monsoon & $0.05( \pm 0.06)$ & $389( \pm 9$ \\
\hline & & & Post-monsoon & $0.14( \pm 0.08)$ & $46.3( \pm 5.0)$ \\
\hline \multirow{3}{*}{$\begin{array}{l}\text { JSM_1(Jomsom) } \\
\text { Kali Gandaki Valley }\end{array}$} & 2800 & $28.87^{\circ} \mathrm{N}, 83.73^{\circ} \mathrm{E}$ & Pre-monsoon & $0.90( \pm 0.45)$ & $39.5( \pm 8.23)$ \\
\hline & & & Monsoon & $0.21( \pm 0.24)$ & $25.1( \pm 6.48)$ \\
\hline & & & Post-monsoon & $0.71( \pm 0.42)$ & $31.4( \pm 4.5)$ \\
\hline
\end{tabular}




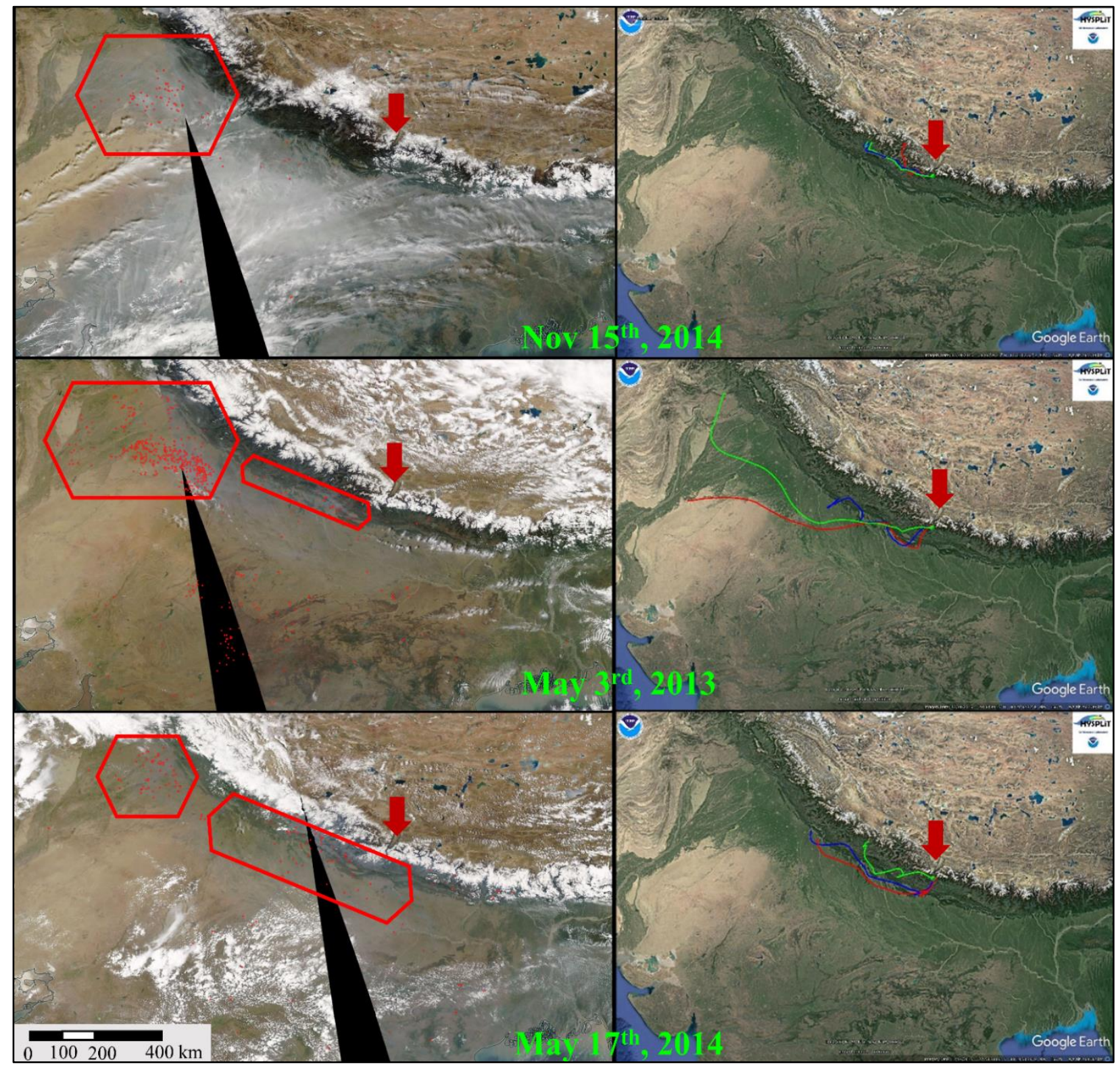

Figure 9 MODIS imagery depicting haze and individual fire events (left) during the regional transport episodes associated with the patterns depicted in Figure 8 and corresponding HYSPLIT back trajectories for those events (right). The red arrows point to the KGV. The black strips are data gap in satellite imagery. 


\section{$\underline{\text { Supplementary materials }}$}

Supplementary Table 1. Regional transport episodes and source location based on (*) MODIS imagery.

\begin{tabular}{|c|c|c|}
\hline \multicolumn{3}{|r|}{$2013(90$ th Percentile $=1.53)$} \\
\hline MONTH & EPISODE LENGTH & SOURCE LOCATION* \\
\hline \multirow{2}{*}{ Jan } & 6th-15th & Widespread regional haze \\
\hline & 28th-31st & Fire in the Punjab region of Pakistan \\
\hline Feb & Jan (contd.)- Feb 2nd & Widespread regional haze \\
\hline \multirow{4}{*}{ Mar } & 1st-3rd & Widespread regional haze along with fires west of Nepal in northern India \\
\hline & 6th-9th & Fire in the Punjab region of Pakistan \\
\hline & 11th-13th & Fire in the Punjab region of Pakistan \\
\hline & 18th-27th & Fire in the Punjab region of Pakistan and scattered fire in Northern India, west of Nepal \\
\hline \multirow{3}{*}{ Apr } & 6th-10th & Fire in the Punjab region of Pakistan and in central and western Nepal \\
\hline & 12th-14th & Fire in the Punjab region of Pakistan and fire in central Nepal \\
\hline & 27th-30th & $\begin{array}{l}\text { Fire in the Punjab region of Pakistan and in Northern India-west of Nepal; Widespread } \\
\text { regional haze }\end{array}$ \\
\hline May & 3rd-11th & Fire in the punjab region of India (over 100 events) and in Pakistan \\
\hline Oct & 28th-30th & Fire in the punjab region of India and Pakistan and widespread regional haze \\
\hline \multirow{2}{*}{ Nov } & 1st-5th & Fire in the punjab region of India and widespread regional haze \\
\hline & 23rd-30th & Widespread regional haze \\
\hline Dec & 17th-24th & Widespread regional haze \\
\hline \multicolumn{3}{|r|}{2014 (90th Percentile $=1.60)$} \\
\hline MONTH & EPISODE LENGTH & SOURCE LOCATION* \\
\hline Jan & 13th-15th & High cloud cover \\
\hline Feb & Jan31st-Feb 1st & High cloud cover \\
\hline Mar & 14th-16th & Fire in Punjab region of Pakistan \\
\hline \multirow{2}{*}{ Apr } & 5th-8th & Fire in central and western Nepal and Haze \\
\hline & 10th-30th & Fire events in Punjab, India and Pakistan \\
\hline \multirow{3}{*}{ May } & Apr 10th-May 1st & Fire in western Nepal, central India and Punjab, Pakistan \\
\hline & 8th-13th & Fire in western Nepal and over 150 fire events in the Punjab region of India and Pakistan \\
\hline & 17th-23rd & $\begin{array}{l}\text { Fire in India-west of Nepal- and over } 100 \text { fire events in the Punjab region of India and } \\
\text { Pakistan }\end{array}$ \\
\hline \multirow{2}{*}{ Jun } & 5th-8th & Fire in India-west of Nepal (Uttarakhand-India) \\
\hline & 10th-17th & Fire in the foothills of the Himalaya (western Nepal and northern India-west of Nepal \\
\hline Nov & 15th-30th & Widespread regional haze and fire events in India \\
\hline Dec & Nov 15th-Dec 8th & Widespread regional haze and a few fire events in Punjab, Pakistan \\
\hline \multicolumn{3}{|r|}{$2015(90$ th Percentile $=1.47) *$} \\
\hline MONTH & EPISODE LENGTH & SOURCE LOCATION* \\
\hline \multirow{2}{*}{ Jan } & 15th-17th & Cloudy/indeterminant \\
\hline & 21st-25th & Cloudy/indeterminant \\
\hline Feb & 21st-26th & Cloudy/indeterminant \\
\hline \multirow{3}{*}{ May } & 6th-9th & Extensive burning (over 200 fire events) in Punjab region of Pakistan and India \\
\hline & 18th-26th & Fire events in the western region of Nepal and Northen India- southwest of Nepal \\
\hline & 29th-31st & Fire in northern India-west of Nepal (Uttarakhand) and western Nepal \\
\hline Jun & 6th-12th & Fire in northern India-west of Nepal (Uttarakhand) and western Nepal \\
\hline
\end{tabular}



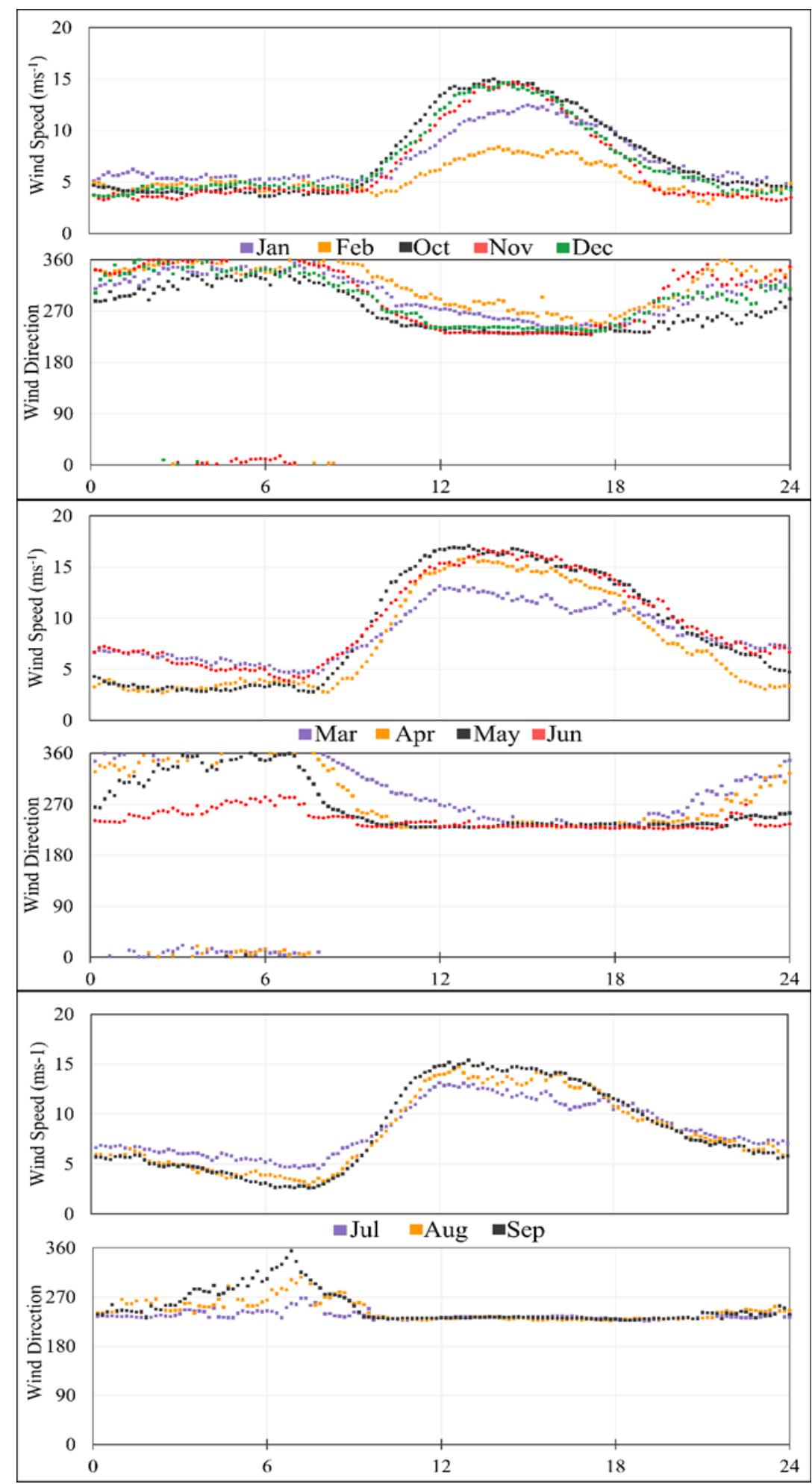

Supplementary Figure 1. Average diurnal variablity in wind speed and direction for each month of 2013 at JSM_AWS_2 during the pre-monsoon (upper two panels), post-monsoon (middle two panels), and monsoon (lower two panels) periods. 


\section{CHAPTER 3. VERTICAL DISTRIBUTION OF TROPOPSHERIC OZONE OVER THE HIMALAYAN REGION DURING WINTER}

\section{$\underline{\text { Abstract }}$}

Tropospheric ozone $\left(\mathrm{O}_{3}\right)$ is a short-lived pollutant that impacts climate and originates from both anthropogenic and natural sources including photochemical reactions involving nitrogen oxides and volatile organic compounds and transport from the stratosphere. Tropospheric $\mathrm{O}_{3}$ modulates the atmospheric lifetime of many atmospheric gases and influences climate via direct radiative forcing. In response to emissions of precursors associated with economic and industrial growth, tropospheric $\mathrm{O}_{3}$ concentrations over Asia have increased over the past decades. Surface measurements over the Himalaya and vertical profiles measured over the Tibetan plateau suggest that stratospheric air influences the vertical distribution of $\mathrm{O}_{3}$ in the region. To evaluate relative contributions from surface emissions versus transport from the stratosphere, 29 ozonesondes were launched from the Himalayan foothills in Nepal during December 2015 and January 2016. Results provide the first measurements of $\mathrm{O}_{3}$ vertical distributions along the southern slopes and over the Himalayan range. Potential vorticity (PV), relative humidity, and potential temperature were interpreted to distinguish influences of stratospheric air. Relative to air over the Himalaya, $\mathrm{O}_{3}$ concentrations between 3 and $10 \mathrm{~km}$ altitude in air over the foothills to the south averaged 10 ppbv higher. Relative to periods of low $\mathrm{PV}, \mathrm{O}_{3}$ concentrations between 9 and $13 \mathrm{~km}$ altitude during periods of high $\mathrm{PV}$ averaged $\sim 10$ to 20 ppbv higher. $\mathrm{O}_{3}$ enhancements, compared to the median for all profiles, below $5 \mathrm{~km}$ (lower troposphere) were seen in $65 \%$ of the profiles due to possible surface sources while $50 \%$ of profiles in the mid-troposphere (5 to $10 \mathrm{~km}$ ) and $46 \%$ in the upper-troposphere (10 to $20 \mathrm{~km}$ ) suggested stratospheric influence. Our observations support the hypothesis that the $\mathrm{O}_{3}$ concentrations over the southern slopes of the Himalayan range are influenced by both surface emissions of precursors and stratosphere-troposphere exchange events.

\section{Introduction}

Tropospheric ozone $\left(\mathrm{O}_{3}\right)$ is integral to atmospheric chemistry, acting as the primary precursor of the oxidizing hydroxyl radical, which modulates the atmospheric lifetime of many atmospheric gases (Thompson, 1992). Tropospheric $\mathrm{O}_{3}$ is a short-lived climate pollutant that influences 
climate via direct radiative forcing. $\mathrm{O}_{3}$ is a greenhouse gas that traps outgoing radiation. Rising emissions of tropospheric $\mathrm{O}_{3}$ precursors since the Industrial revolution has increased radiative forcing by approximately $0.40 \mathrm{~W} \mathrm{~m}^{-2}$ (IPCC, 2014). $\mathrm{O}_{3}$ at higher altitude in the atmosphere has greater impact on radiative forcing than at surface. Increasing $\mathrm{O}_{3}$ concentrations in conjunction with increasing $\mathrm{CO}_{2}$ can also reduce gross primary production. Model calculations predict $14 \%$ to $23 \%$ loss in gross primary productivity by 2100 thereby suppressing the land-carbon sink (Sitch et al., 2007). Pollutant $\mathrm{O}_{3}$ can also adversely impact human pulmonary health (Brook et al., 2004), decrease crop yields (Ghude et al., 2014), and reduce biodiversity (The Royal Society, 2008). Most tropospheric $\mathrm{O}_{3}$ is either produced via photochemical reactions involving nitrogen oxides $\left(\mathrm{NO}_{\mathrm{x}}\right)$ and volatile organic compounds emitted from surface sources or transported from the stratosphere (Crutzen et al., 1995). Concentrations vary in response to proximity to precursor sources, topography, UV radiation, temperature, relative humidity (RH), and atmospheric transport (Monks, 2000; Ganguly and Tzanis, 2013). If mixed into the free troposphere, $\mathrm{O}_{3}$ can be transported over long distances and modulate concentrations downwind (Fiore et al., 2003; Cooper et al., 2010).

Concentrations of tropospheric $\mathrm{O}_{3}$ and the frequency of extreme events over Asia have increased temporally (e.g., Dickerson et al., 2007; Ohara et al., 2007, Wang et al., 2009) in response to industrial and economic growth (Akimoto, 2003). Anthropogenic combustion sources including wildfires, biomass and biofuel burning, and fossil-fuel combustion emit volatile and particulatephase compounds to the atmosphere that contribute to the persistent regional haze visible in satellite imagery during winter. Anthropogenic emissions from power plants, vehicles, biofuel combustion are present year round (Reddy and Ventakaraman, 2002). However, emissions from agricultural burning during harvest seasons (March- May and September-November) in northern India can increase average $\mathrm{O}_{3}$ concentrations in the lower troposphere by about 20 ppbv and in the mid-troposphere by about 30 ppbv over average seasonal concentrations (Ojha et al., 2014). High near-surface $\mathrm{O}_{3}$ concentrations over densely populated areas of northern India coincide with high $\mathrm{NO}_{\mathrm{x}}$ concentrations from anthropogenic sources (Fishman et al., 2003; Ghude et al., 2013). $\mathrm{O}_{3}$ concentrations over western India were found to be enhanced above average concentrations during transport of air masses with longer residence times over continental versus marine regions and exhibited lowest concentrations during monsoon season when the air masses were primarily of marine origin and agricultural combustion was minimal (Srivastava, 2012; Lal 
et al., 2014). Ozonesondes launched in western India coupled with back trajectories show that regional pollution sources increase $\mathrm{O}_{3}$ concentrations in the lower troposphere by $20 \%$ to $40 \%$ relative to background levels $(47.7( \pm 3.2)$ ppbv) during winter (Srivastava et al., 2012). In addition, model simulations show strong mid-troposphere winds can transport biomass-burning emissions from Africa to the higher Himalaya (Kopcaz et al., 2011).

The downward transport of stratospheric $\mathrm{O}_{3}$ during large-scale stratosphere-troposphere exchange (STE) events also contributes to tropospheric $\mathrm{O}_{3}$. The intensity of STE events varies spatially and temporally. STE episodes can produce high $\mathrm{O}_{3}$ concentrations (up to approximately $100 \mathrm{ppbv}$ ) at sea level and greater than $250 \mathrm{ppbv}$ in mountainous regions (Davies and Schuepbach, 1994). In the Northern mid-latitudes $\mathrm{O}_{3}$-rich stratospheric air is injected into the troposphere primarily during spring and winter due to frequent upper level cyclogenesis and tropopause folding associated with synoptic features associated with the polar front, frontal passages and cut-off lows (Monks, 2009). Tropopause folds near the subtropical westerly jet stream can enhance STE through the development of multiple tropopause heights and associated intermixed layers of stratospheric and tropospheric air (Randal et al., 2007). Radiosonde observations over the Tibetan Plateau (TP) reveal a high frequency ( $~ 80 \%$ of all profiles) of multiple thermal tropopauses during winter (Chen et al., 2011). Stable potential temperature (hereafter referred to as theta) and low RH over the Tibetan Plateau during winter can potentially enhance the downward transport of $\mathrm{O}_{3}$ rich dry eddies of stratospheric origin as a part of BrewerDobson circulation (Chen et al., 2013; Bracci et al., 2012; Hocking et al., 2007). Model calculations, surface observations, and back trajectories suggest that stratospheric intrusions in the Himalayan region occur most frequently during winter and early spring (Cristofanelli et al., 2010; Chen et al. 2013). STE events have also been detected during winter over the Indian plains (Gupta et al., 2007) and at the edge of the Himalayan foothills (Ojha et al., 2014). These observations suggests that stratospheric $\mathrm{O}_{3}$ can be a significant source of tropospheric $\mathrm{O}_{3}$ during winter in the Himalayan region. However, the percentage of days affected by STE events is lower than that observed at high altitude locations in central and Western Europe where polar jets and cyclogenesis are frequent (Cristofanelli et al., 2010). Low RH, high potential vorticity (PV) and high theta are often used to characterize STE events. High PV with protruding filaments extend equatorward due to isentropic transport associated with large-scale cyclones and anti-cyclones (Zanis et al., 2003). Under certain synoptic conditions, portions of these high 
PV filaments can be cut off or trapped in characteristically distinct air masses resulting in isolated "streamers" of high PV. These filaments, of dry, high- $\mathrm{O}_{3}$ air can be transported long distances by synoptic scale flow patterns (including jet streams).

Relatively few vertical profiles of $\mathrm{O}_{3}$ have been measured over the Indo-Gangetic plains (IGP) (Srivastava et al. 2012) and a single year-long measurement campaign was conducted in India at the edge of the Himalayan foothills (Ojha et al., 2014). In this paper, we investigate influences of orography, synoptic weather patterns including STE, and regional pollution in modulating vertical profiles of tropospheric $\mathrm{O}_{3}$ in the Himalayan region.

\section{Measurement site and methods}

Between December 29, 2015 and January 7, 2016, twenty nine ozonesondes were launched from the city of Pokhara $\left(28.12^{\circ} \mathrm{N}, 83.58^{\circ} \mathrm{E}, 800 \mathrm{~m}\right.$ asl, population of 400,000$)$ situated in a valley about $30 \mathrm{~km}$ from the Himalayan range (Table 1, Fig. 1). Five of the sondes yielded incomplete information ( 2 missing GPS location and 3 flights terminated lost radio communication). The following analysis is based on data for the other 26 sondes expect for ozonesonde path based analysis includes only 24 sondes are analyzed since 2 sondes did not have GPS data.

Synoptic weather in the region surrounding Pokhara is influenced by oscillation of the subtropical westerly jet (October to May) and the summer monsoon anticyclone (June to September) (Bonasoni, 2010). Extensive haze over the Indo-Gangetic Plain (IGP) during dry seasons is typically evident in MODIS (Moderate Resolution Imaging Spectroradiometer), imagery and was present throughout the duration of the measurement campaign.

$\mathrm{O}_{3}$ mixing ratios were measured with electrochemical sensors (ECC/EN-SCI model $2 \mathrm{z}$ ) and ambient pressure, temperature, theta, wind speed (WS), wind direction (WD), and RH were measured in parallel with coupled meteorological radiosondes (i-Met $403 \mathrm{MHz}$ GPS). The sondes were flown with $1200 \mathrm{~g}$ rubber balloons and ascended at an average rate of approximately $5 \mathrm{~m} \mathrm{~s}^{-}$

1. The absolute accuracy of $\mathrm{O}_{3}$ mixing ratios greater than $100 \mathrm{ppbv}$ varied as a function of altitude from $\pm 5 \%$ to $\pm 10 \%$ and precision varied from $\pm 3 \%$ to $\pm 5 \%$ (Smith, et al., 2007). Pressure offsets were corrected using the geopotential height and GPS altitude from the radiosonde. Theta, WS, and RH were integrated over 1-s time intervals and $\mathrm{O}_{3}$ was integrated over 100-m altitude intervals. In addition, global PV anomalies were calculated at $250 \mathrm{hPa}$ using Modern-Era 
Retrospective analysis for Research and Applications, version 2 (MERRA-2) (Bosilovich, 2015). MERRA-2 provides long-term global reanalysis based on assimilated aerosol observations from satellites and associated interactions with physical processes.

\section{Results and Discussions}

\subsection{Partitioning ozonesondes based on flight path and PV}

Figure 2 depicts percentile distributions $\left(25^{\text {th }}, 50^{\text {th }}\right.$ and $\left.75^{\text {th }}\right)$ for all vertical profiles of $\mathrm{O}_{3}, \mathrm{RH}$, WS, and theta and summary statistics are reported in Table 1 . Based on median values, $\mathrm{O}_{3}$ concentrations in the troposphere increased from $43 \mathrm{ppbv}$ in the lowest $2 \mathrm{~km}$ to $130 \mathrm{ppbv}$ near the tropopause at 14 to $16 \mathrm{~km}$. Median concentrations increased sharply at higher altitudes within the stratosphere. Median RH decreased from greater than $60 \%$ in the lowest $4 \mathrm{~km}$ to less than $23 \%$ at higher altitudes. The lapse rate of theta is generally positive (greater than 0), which indicates generally stable tropospheric conditions (Table 1). $\mathrm{O}_{3}, \mathrm{RH}, \mathrm{WS}$, and temperature (not shown) profiles were in good agreement with those measured over Nainital, India $\left(29.4^{\circ} \mathrm{N}\right.$, $79.5^{\circ} \mathrm{E}$ ) during winter 2011 (Ojha et al., 2014). In Addition, wind velocities peak between 10 and $18 \mathrm{~km}$ in association with sub-tropical westerly jet (SJS) similar to the findings the magnitude, location and variability seen in the profiles from Nainital.

Thirteen sondes were transported to the northeast or crossed over the Himalayan range (hereafter referred to as $\mathrm{N}$ ) while 11 sondes were transported to the east and remained south of the Himalayan range (hereafter referred to as S, Fig. 3). Vertical profiles (Fig. 4) provide insight regarding the impact of the Himalaya on $\mathrm{O}_{3}$ distributions. The median distribution profiles for $\mathrm{O}_{3}$ concentrations measured by $\mathrm{N}$ - and S-sondes exhibit similar concentrations within the lower troposphere (below $5 \mathrm{~km}$ ). However, the S-sondes recorded relatively higher concentrations ( $\sim 10$ ppbv based on median values) between 6 and $10 \mathrm{~km}$. At $14 \mathrm{~km}$, median $\mathrm{O}_{3}$ concentrations measured by S-sondes increased sharply by about 100 ppbv while N-sondes exhibited a comparable change at $16 \mathrm{~km}$, suggesting a difference in the height of the tropopause. Generally, dryer air masses ( $\mathrm{RH}$ less than 25\%) were measured by both $\mathrm{N}$ - and $\mathrm{S}$-sondes when $\mathrm{O}_{3}$ concentrations were 10 ppbv higher than the median. For N-sondes, median theta profiles between 4 and $10 \mathrm{~km}$ altitude indicate a neutral atmosphere with no relative change in lapse rate. Isothermal layers near the tropopause are indicative of STE. Windspeeds between 10 and $16 \mathrm{~km}$ 
altitude was about $20 \mathrm{~m} \mathrm{~s}^{-1}$ greater. We observed greater variability in the $\mathrm{O}_{3}$ concentrations in the sondes that crossed the Himalaya than those that stayed south of the Himalaya. MERRA-2 wind data at 140 and $250 \mathrm{mb}$ (Supplementary Fig. 1) indicated that that flight paths were driven by synoptic circulation. An upper-level ridge over the region transported the sondes over the Himalaya to the North while upper-level trough transported them to the south.

Profiles were also partitioned into two categories based on MERRA-2 PV maps at $250 \mathrm{hPa}$ (Fig. 5). PV anomaly maps were generated by calculating the difference between mean PV values from 1982 to 2010 at $1200 \mathrm{Z}$ and global PV mean at $1200 \mathrm{Z}$ for the launch day. The positive anomalies show higher PV while negative anomalies indicate lower PV values. Ozonesondes were stratified into two groups that were launched when PV anomalies over the Himalaya were greater than (16 profiles) and less than (10 profiles) 1.5 PVU (Fig. 6). This partitioning provides insight regarding potential contributions of stratospheric $\mathrm{O}_{3}$ in the upper troposphere via STE (Stohl et al., 2000). Median $\mathrm{O}_{3}$ profiles in the lower troposphere (below $5 \mathrm{~km}$ ) during periods of high and low PV were similar as might be expected since high PV is indicative of stratospheric air and is pronounced in mid- and upper troposphere. During periods of high PV, median $\mathrm{O}_{3}$ concentrations in the mid- to upper troposphere (6 to $13 \mathrm{~km}$ ) were about 20 ppbv greater relative to those during periods of low PV. Concentrations at altitudes greater than $13 \mathrm{~km}$ were similar during periods of both high and low PV. During periods of high PV, the relatively low RH ( $\sim 15$ $\%$ ) and high $\mathrm{O}_{3}$ concentrations above $10 \mathrm{~km}$ are also consistent with stratospheric influences. These results suggest that the high $\mathrm{O}_{3}$ air may have been transported to the region either via active tropopause folding over the Himalaya or by advection of air mass from tropopause folding events upwind. This will be addressed further in Chapter four where we make use of model cross sections.

\subsubsection{Case studies - High $\mathrm{O}_{3}$ in the lower troposphere}

We looked for evidence of $\mathrm{O}_{3}$ layers that have regional pollution origin, rather than an origin in the upper troposphere. These layers would be expected to have higher RH and lower theta representing transport from near the surface. Seventeen of the $26 \mathrm{O}_{3}$ profiles $(65 \%$ of the total profiles) exhibited one or more peaks in $\mathrm{O}_{3}$ concentrations within the lower troposphere (between surface and $5 \mathrm{~km}$ altitude) that exceeded the corresponding $50^{\text {th }}$ percentile for that 
altitude based on all profiles (Table 1; Supplementary Fig. 2). These relatively high $\mathrm{O}_{3}$ concentrations were characterized as "enhanced". Among the enhanced profiles, we analyze three profiles that exhibited peaks above $75^{\text {th }}$ percentile $(55 \mathrm{ppbv})$ to discern surface or stratospheric influence.

Ozonesonde flight, flt13, between 2.5 and $3.25 \mathrm{~km}$ and again between 3.5 and $4.75 \mathrm{~km}$ showed peaks above the 55 and 65 ppbv at two altitudes. When these peaks were compared to their RH (Fig. 7A) and theta (Fig. 7B), the lowest peak layer was relatively moist (RH above 45\%) and theta was below $300 \mathrm{~K}$. These point to the fact that the peak between 2.5 and $3.25 \mathrm{~km}$ was potentially a result of surface emissions. However, the second peak between 3.5 and $4.75 \mathrm{~km}$ was in a layer that had decreasing RH and rising theta values which could possibly have resulted due to adiabatic subsidence of STE enhanced upper tropospheric air.

Flt16 shows peak $\mathrm{O}_{3}$ values (58 ppb) in layer between $1.5 \mathrm{~km}$ and $3 \mathrm{~km}$ (Fig. 8). This is a relatively moist layer of air with RH increasing from above $30 \%$ to above $50 \%$ and theta under $300 \mathrm{~K}$. The meteorological variables again suggest influence from surface emissions. Similarly, flt20 between 1.5 and $3 \mathrm{~km}$ peaked above 55 ppbv with $55 \% \mathrm{RH}$ and theta below $310 \mathrm{~K}$ indicating a surface influence (Fig. 9).

MODIS imagery and CALIPSO (Cloud-Aerosol Lidar and Infrared Pathfinder Satellite Observation) show haze layers as deep as $3 \mathrm{~km}$ (not shown) over the Indo-Gangetic plains (IGP) during our study period. We observe median $\mathrm{O}_{3}$ concentrations around $50 \mathrm{ppbv}$ within this the haze layer which is similar to background concentrations, during winter, in Ahmedabad, Western India (47.7 ( \pm 3.2$)$ ppbv, Srivastava et al. 2012) and Nainitaal (about 50 ppbv, Ojha et. al 2014). This appears to suggests minimal impact of the haze layer in $\mathrm{O}_{3}$ concentration in the lower troposphere, although individual events as shown above can exhibit peak values enhanced by at least $5 \mathrm{ppb}$. More studies incorporating $\mathrm{O}_{3}$ precursors and regional chemical modeling like GEOS-Chem and WRF-Chem are needed to delineate the sources and paths of transport in the lower troposphere during these winter haze conditions. 


\section{$\underline{\text { 3.1.2 Case studies - High } \mathrm{O}_{3} \text { in the mid-troposphere }}$}

Thirteen of the $26 \mathrm{O}_{3}$ profiles ( $50 \%$ of total profiles) had $\mathrm{O}_{3}$ layers above $50^{\text {th }}$ percentile (Supplementary Fig. 3). Profiles with peaks above the $75^{\text {th }}$ percentile (Table 1) were looked at in detail using RH and theta to provide insight regarding relative influences of surface-based emissions or stratospheric sources on $\mathrm{O}_{3}$ concentrations.

Flt09 observed $\mathrm{O}_{3}$ above 70 ppbv between 6 to $7 \mathrm{~km}$ with $\mathrm{RH}$ below $20 \%$ and increasing theta value close to $320 \mathrm{~K}$ (Fig. $10 \mathrm{~A}$ and B). The dry layer with relatively high theta values suggest stratospheric influence in that particular layer. Again, a second peak between 7.25 and $8.25 \mathrm{~km}$ was observed in flt09 with similar moisture content but higher theta value (above $320 \mathrm{~K}$ ). The peaks in this profile are probably due to subsidence of an air mass of stratospheric origin.

Similarly, flt10b also showed high $\mathrm{O}_{3}$ between 7.5 to $8 \mathrm{~km}$ and then again from $8.3 \mathrm{~km}$ and above (Fig. $11 \mathrm{~A}$ and $\mathrm{B}$ ) state the $\mathrm{O}_{3}$ concentration. Both the high $\mathrm{O}_{3}$ layers were dry with around $10 \% \mathrm{RH}$ and theta above $320 \mathrm{~K}$. This shows a clear stratospheric influence.

The peaks at altitude between 8.5 and $9 \mathrm{~km}$ then again from 9.2 and above in flt13 were dry (below 20\% RH) with theta values above $320 \mathrm{~K}$ (Fig. 12 A and B). These layers exhibited O3 concentrations of

Occurrence of rich- $\mathrm{O}_{3}$ layers in dry air mass with high theta values in the mid-troposphere shows that the air in the Himalayan region is frequently influenced by stratospheric air. Our findings are consistent with Cristofanelli et al., (2010), who observed stratospheric influence in $\mathrm{O}_{3}$ concentrations in higher Himalaya during winter season. In order to understand the path and sources of transport isentropic back trajectories and regional transport models should be used. Isentropic back trajectories will help discern the transport of $\mathrm{O}_{3}$ between subsidence of active tropopause folding and STE over the Himalayan and advection from locations upwind of the Himalayan region.

\section{$\underline{\text { 3.1.3 Case studies - High } \mathrm{O}_{3} \text { in the upper-troposphere }}$}

We looked at 12 profiles ( $46 \%$ of the total) with enhanced $\mathrm{O}_{3}$ in the upper troposphere between altitudes 10 and $20 \mathrm{~km}$ (Supplementary Fig. 4). Eight of the enhanced profiles show rapid 
increase in $\mathrm{O}_{3}$ concentrations above $14 \mathrm{~km}$. In this section, we look at the three profiles that show the greatest increase in $\mathrm{O}_{3}$ concentrations in the upper troposphere. $\mathrm{O}_{3}$ concentrations in flt 24 increase rapidly (about $270 \mathrm{ppbv}$ increase) between 13 and $15 \mathrm{~km}$ in a dry environment (less than $15 \%$ ) with theta above $350 \mathrm{~K}$. This clearly indicates stratospheric influence (Fig. $13 \mathrm{~A}$ and B).

Flt 25 shows $\mathrm{O}_{3}$ peak between 13.5 and $15 \mathrm{~km}$, with $\mathrm{O}_{3}$ profile suggestive of a tropopause folding like event with $\mathrm{O}_{3}$ concentrations decreasing before increasing again (Fig. 14). The $\mathrm{RH}$ (less than 16\%) and theta (above $350 \mathrm{~K}$ ) profiles again show a strong stratospheric influence. Figure 15 shows $\mathrm{O}_{3}$ concentrations increasing above $13.5 \mathrm{~km}$ with $\mathrm{O}_{3}$ profile similar to that of flt25. These observations show that stratospheric air has an influence on the vertical distribution of $\mathrm{O}_{3}$ in the southern slopes of the Himalaya as illustrated by Chen et al., (2011) along the northern slopes of the Tibetan Plateau.

Although stratospheric influences are clearly evident in these vertical profiles of $\mathrm{O}_{3}$ over the Himalaya, further studies using satellite assimilation data, isentropic back trajectories and model calculations would help us to understand the dynamics of STE in this region during winter.

\section{Conclusion}

Our observations indicate that regional pollution arising from surface emissions have some impact in the lower troposphere. The more obvious influence on the vertical distribution of ozone is that of stratosphere to troposphere exchange resulting in layers of enhanced ozone in the mid- and upper troposphere over the Himalaya. Specifically:

- $\mathrm{O}_{3}$ concentrations in the mid troposphere (6 to $10 \mathrm{~km}$ ) south of the Himalaya range were approximately $10 \mathrm{ppbv}$ higher that those measured at the same altitude over the Himalaya.

- $\mathrm{O}_{3}$ concentrations between 9 and $13 \mathrm{~km}$ altitude during periods of high PV (>1.5) were 10 to 20 ppbv higher than those at the same altitude during periods of lower PV. In contrast, $\mathrm{O}_{3}$ concentrations in the lower troposphere did not vary systematically as a function of PV. 
- Mid- and upper-troposphere were observed to have higher stratospheric influence than surface influence.

- Possible signatures of stratospheric intrusions as low as $7.5 \mathrm{~km}$ were detected using corresponding RH and theta profiles.

The next chapter addresses the apparent dynamics of these exchange events, and how conditions in the upper troposphere varied over the time frame of this month-long ozonesonde campaign.

\section{$\underline{\text { Acknowledgements }}$}

We would like to acknowledge our field assistant in Nepal, Bhogendra Kathayat, Anil Patel, Dipendra Pokhrel, Gupta Bahadur Singh Giri, Mahesh Giri and Manoj Giri who helped us during ozonesonde launch. We would like to thank the staff at Pokhara Airport tower for their cooperation during the launch. Financial support was provided by the National Aeronautics and Space Administration NNX12AC60G, and additional field support was provided by ICIMOD's Atmosphere Initiative. The authors are very thankful for comments from William Keene. 


\section{$\underline{\text { References }}$}

Akimoto, H.: Global air quality and pollution, Science, 302, 1717-1719, 2003.

Bosilovich, M. G., et al., MERRA-2: Initial evaluation of the climate. Series on Global Modeling and Data Assimilation Tech. Rep. NASA/TM-2015-104606, Vol. 43, 145 pp, 2015.

Bonasoni, P., Laj, P., Marinoni, A., Sprenger, M., Angelini, F., Ar- duini, J., Bonafe, U., Calzolari, F., Colombo, T., Decesari, S., Di Biagio, C., di Sarra, A. G., Evangelisti, F., Duchi, R., Facchini, M. C., Fuzzi, S., Gobbi, G. P., Maione, M., Panday, A., Roccato, F., Sellegri, K., Venzac, H., Verza, G. P., Villani, P., Vuillermoz, E., and Cristofanelli, P.: Atmospheric Brown Clouds in the Himalayas: first two years of continuous observations at the Nepal Climate Observatory-Pyramid (5079 m), Atmos. Chem. Phys., 10, 7515-7531, doi:10.5194/acp-10-7515-2010, 2010.

Bracci, A., P. Cristofanelli, M. Sprenger, U. Bonafe, F. Calzolari, R. Duchi, P. Laj, A. Marinoni, F. Roccato, E. Vuillermoz, and P. Bonasani, Transport of stratospheric air masses to the Nepal Climate Observatory-Pyramid (Himalaya; 5079m MSL): A synoptic-scale investigation, Am. Meteorol. Soc., DOI:10.1175/JAMC-D-11-0154.1, 2012.

Brook, R. D., Franklin, B., Cascio, W., Hong, Y., Howard, G., Lipsett, M., Luepker, R., Mittleman, M., Samet, J., Smith, S. C., Tager, I.: Air pollution and cardiovascular disease: A statement for the healthcare professionals from the expert panel on population and prevention science of the American Heart Association, Circulation, 109, 2655-2671, 2004.

Chen, X., J. A. Anel, Z. Su, L. de la Torre, H. Kelder, J. V. Peet, and Y. Ma, The deep ABL and its significance to the stratosphere and troposphere exchange over Tibetan Plateau, PLos ONE, 8, 2, 1-8, 2013.

Chen, X.L., Ma, Y.M., Kelder, H., Su, Z., Yang, K.: On the behavior of the tropopause folding events over the Tibetan Plateau. Atmos. Chem. Phys. 11, 5113-5122, 2011.

Cooper, O. R.., Parrish, D. D., Stohl, A., Trainer, M., Nédélec, P., Thouret, V., Cammas, J. P., Oltmans, S. J., Johnson, B. J.. Tarasick, D., Leblanc, T., McDermid, I. S., Jaffe, D., Gao, R., Stith, J., Ryerson, T., Aikin, K., Campos, T., Weinheimer, A., Avery, M. A.: Increasing 
springtime ozone mixing ratios in the free troposphere over western North America, Nature, 462, 344-348, 2010.

Cristofanelli, P., A. Bracci, M. Sprenger, A. Marinoni, U. Bonafe, F. Calzolari, R. Duchi, P. Laj, J.M. Pichon, F. Roccato, H. Venzac, E. Vuillermoz, and P. Bonasoni, Tropospheric ozone variations at the Nepal Climate Observatory-Pyramid (Himalaya; 5079m MSL) and influence of deep stratospheric intrusion events, Atmos. Chem. Phys., 10, 6537-6549, 2010.

Crutzen, P., J.: Ozone in the troposphere, in composition, chemistry and climate of the atmosphere, edited by H. B. Singh, Van Norstand Reinhold, New York, 349-393, 1995.

Davies, T. D. and E. Schuepbach, Episodes of High ozone concentrations at the Earth's surface resulting from transport down from the upper troposphere/lower stratosphere: a review and case studies, Atmosphere and Environment, 28, 1, 53-64, 1994.

Danielsen, E. F.: Stratospheric-Tropospheric exchange based on radioactivity, ozone and potential vorticity, J.Atmos. Sci., 25, 502-518, 1968.

Dickerson, R. R., Andreae, M. O., Campos, T., Mayol-Bracero, O. L. ,Neusuess, C., Streets, D. G.: Analysis of black carbon and carbon monoxide observed over the Indian Ocean: Implications for emissions and photochemistry, J. Geophys. Res., 107(D19), 8017, doi:10.1029/2001JD000501, 2002.

Fiore, A. M., Jacob, D. J., Bey, I., Yantosca, R. M., Field, B. D., Fusco, A. C., and Wilkinson, J. G.: Background ozone over the United States in summer: Origin, trend, and contribution to pollution episodes, J. Geophys. Res., 107(D15), 4275, doi:10.1029/2001JD000982, 2002.

Fishman, J., Wozniak, A.E., Creilson, J.K.: Global distribution of tropospheric ozone from satellite measurements using the empirically corrected tropospheric ozone residual technique: identification of the regional aspects of air pollution, Atmos. Chem. Phys., 3, 893-907, 2003.

Ganguly, N. D., and C. Tzanis, High surface ozone episodes at New, Delhi, India, Springer Berlin Heidelberg, 445-453, 2013.

Ghude, S. D., Jena, C., Chate, D. M., Beig, G., Pfister, G. G., Kumar, R., Ramanathan, V.: 
Reductions in India's crop yield due to ozone, Geophys. Res. Lett., 41, 5685-5691, doi:10.1002/2014GL060930, 2014.

Ghude, S. D., Pfister, G. G., Jena, C., van der A, R. J., Emmons, L. K., and Kumar, R: Satellite constraints of nitrogen oxide (NOx) emissions from India based on OMI observations and WRF-Chem simulations, Geophys. Res. Lett., 40, 2, 423-428, doi:10.1002/grl.50065, 2013.

Gupta, S., Lal, S., Venkataramani, S., Rajesh, T. A., Acharya,Y. B.: Variability in the vertical distribution of ozone over a subtropical site in India during a winter month, J. Atmos. Solar Terr. Phys., 69, 1502-1512, 2007

Hara, Masayuki, Fujio Kimura, and Tetsuzo Yasunari. "The generation mechanism of the western disturbances over the Himalayas." 6th international GAME conference. 2004.

Hocking, W., K., T. Carey-Smith, D. W. Tarasick, P. S. Argall, K. Strong, Y. Rochon, I. Zawadski and P. A. Taylor, Detection of stratospheric ozone intrusions by windprofiler radars, Nature Letters, DOI:10.1038/nature06312, 2007.

IPCC: Synthesis Report. Contribution of Working Groups I, II and III to the Fifth Assessment Report of the Intergovernmental Panel on Climate Change IPCC, Geneva, Switzerland, 151 pp, 2014.

James, P., Scheel, H. E., Stohl, A., and Trickl, T.: Deep Stratospheric Air Intrusions Case Studies and Climatology, Procced. of EUROTRAC Symposium 2002, P. M. Midgley, M. Reuther (Eds), Margraf Verlag (Germany 2002), contribution TOR-12 (5 pp. on CD), 2002.

Kopacz, M., Mauzerall, D. L., Wang, J., Leibensperger E. M., Henze, D. K., Singh, K.: Origin and radiative forcing of black carbon transported to the Himalayas and Tibetan Plateau. Atmos. Chem. Phys., 11. 2837-2852, 2011.

Kumar, R., M. Naja, S. Venkataramani, and O. Wild (2010), Variations in surface ozone at Nainital: A high-altitude site in the central Himalayas, J. Geophys. Res., 115, D16302, doi:10.1029/2009JD013715.

Lal, S., Venkataramani, S., Chandra, N., Cooper,O. R., Brioude, J., Naja M.: Transport effects on 
the vertical distribu- tion of tropospheric ozone over western India, J. Geophys. Res. Atmos., 119, 10,012-10,026, doi:10.1002/ 2014JD021854, 2014.

Logan, J. A. Trends in the vertical distribution of ozone: An analysis of ozonesonde data, J. Geophys. Res., 99, D12, 25,553-25, 585, 1994.

Monks, P.S., Granier, C., Fuzzi, S., Stohl, A., Williams, M.L., Akimoto, H., Amann, M., Baklanov, A., Baltensperger, U., Bey, I., Blake, N.: Atmospheric composition changeglobal and regional air quality. Atmospheric environment, 43(33), pp.5268-5350, 2009.

Moore, G. W. K. and Semple, J. L.: High Himalayan meteorology: weather at the south col of mount Everest, J. Res. Lett., 31, doi:10.1029/2004GL020621, 2004.

Ohara, T., Akimoto, H., Kurokawa,J., Horii,N., Yamaji, K., Yan, X., Hayasaka, T.: Asian emission inventory for anthropogenic emission sources during the period 19802020, Atmos. Chem. Phys., 7, 4419-4444, 2007.

Ojha, N., Naja, M., Sarangi, T., Kumar, R., Bhardwaj, P., Lal, S., Venkataramani S., Sagar, R., Kumara, A., Chandola, H. C.: On the processes influencing the vertical distribution of ozone over the central Himalayas: Analysis of yearlong ozonesonde observations, Atmos., Env., $88,201-211,2014$.

Randel, W. J., Seidel, D. J., and Pan, L. L.: Observational charac- teristics of double tropopauses, J. Geophys. Res., 112, D07309, doi:10.1029/2006JD007904, 2007.

Reiter, R.: On the mean daily and seasonal variations of the vertical ozone profiles in the lower troposphere. Atmospheric Environment 25A, 1751-1757, 1991.

Sahu, L. K. Volatile organic compounds and their measurement in the troposphere. Current Science, 102(12), 1645-1649, 2012.

Sahu, L.K. and Saxena, P.: High time and mass resolved PTR-TOF-MS measurements of VOCs at an urban site of India during winter: Role of anthropogenic, biomass burning, biogenic and photochemical sources. Atmospheric Research, 164, pp.84-94, 2015. 
Seinfield, J. H. and Pandis, S. N. Atmospheric Chemistry and Physics: From air pollution to Climate change, New York: John Wiley \& Sons, 1997.

Smit, H. G. J., et al., Assessment of the performance of ECC-ozonesondes under quasi-flight conditions in the environmental simulation chamber: Insights from the Juelich Ozone Sonde Intercomparison Experiment (JOSIE), J. Geophys. Res., 112, D19306, doi:10.1029/2006JD007308 (2007).

Srivastava, S., Lal, S., Naja, M., Venkataramani, S., Gupta, S.: Influence of regional pollution and long range transport over western India: analysis of ozonesonde data, Atmos. Environ., doi.org/10.1016/j.atmosenv.2011.11.018, 2012.

Stohl, A., Bonasoni, P., Cristofanelli, P., Collins, W., Feichter, J., Frank, A., Forster, C., Gerasopoulos, E., Gaggeler, H., James, P., Kentarchos, T., Kreipl, S., Kromp-Kolb, H., Kruger, B., Land, “ C., Meloen, J., Papayannis, A., Priller, A., Seibert, P., Sprenger, M., Roelofs, G. J., Scheel, E., Schnabel, C., Siegmund, P., Tobler, L., Trickl, T., Wernli, H., Wirth, V., Zanis, P., Zerefos, C.: Stratosphere-troposphere exchange a review, and what we have learned from STACCATO, J. Geophys. Res., 108(D12), doi:10.1029/2002JD002490, 2003.

Sitch, S., Cox, P. M., Collins, W. J., Huntingford, C.: Indirect radiative forcing of climate change through ozone effects in the land-carbon sink, Nat. Lett., 448, 791-794, 2007.

Stohl, A., Spichtinger-Rakowsky, N., Bonasoni, P., Feldmann, H., Memmesheimer, M., Scheel, H. E., Trickl, T., Hubener, S., Ringer W., and Mandl, M.: The influence of stratospheric intrusions on alpine ozone concentrations, Atmos. Environ., 34(9), 1323-1354, 2000.

Sullivan, J. T., McGee, T. J., Thompson, A. M., Pierce, R. B., Sumnicht, G. K., Twigg, L. W., Eloranta, E., Hoff, R. M.: Characterizing the lifetime and occurrence of stratospherictropospheric exchange events in the rocky mountain region using high-resolution ozone measurements, J. Geophys. Res. Atmos., 120, 12,410-12,424, doi:10.1002/2015JD023877, 2015. 
Tanimoto, H.: Increase in springtime tropospheric ozone at a mountainous site in Japan for the period 1998-2006, Atmos. Environ., 43, 1358-1363, doi:10.1016/j.atmosenv.2008.12.006, 2009.

The Royal Society, 2008. Ground-level ozone in the 21st century: future trends, impacts and policy implications. Science policy report 15/08. The Royal Society, London.

Thompson, A. M. The oxidizing capacity of the Earth's atmosphere: Probable past and future changes, Science, 256, 1157-1165, doi10.1126/science.256.5060.1157, 1992.

Tobo, Y., Iwasaka, Y., Zhang, D., Shi, G., Kim., Y-S, Tamura, K., Ohashi, T.:Summertime "ozone valley" over the Tibetan Plateau derived from ozonesondes and EP/TOMS data, Geophys. Res. Lett., 35, L16081, doi:10.1029/2008GL034341, 2008.

Wang, T., Wei, X. L., Ding, A. J., Poon, C. N., Lam, K., S., Li, Y. S., Chan, Y., Anson, M.: Increasing surface ozone concentrations in the background atmosphere of southern China 1994-2007, Atmos. Chem. Phys. 9, 6217-6227 doi:10.5194/acp-9-6217-2009, 2009.

Zanis, P., Trickl, T, Stohl, A., Wernli, H., Cooper, O., Zerefos, C., Gaeggeler, H., Schnabel, C., Tobler L., Kubik, P. W., Priller, A., Scheel, H. E., Kanter, H. J., Cristofanelli, P., Forster, C., James, P., Gerasopoulos, E., Delcloo, A., Papayannis, A., Claude, H.: Forecast, observation and modelling of a deep stratospheric intrusion event over Europe, Atmos. Chem. Phys., 3, 763-777, 2003.

Zhang, Y., Liu, H., Crawford, J. H., Considine, D., B., Chan, C., Oltmans, S. J., Thouret, V.: Distribution, variability and sources of tropospheric ozone over the south China in spring: Intensive ozonesonde measurements at five locations and modeling analysis, J. Geophys. Res., 117, D12304, doi:10.1029/2012JD017498, 2012. 


\section{$\underline{\text { Figures }}$}

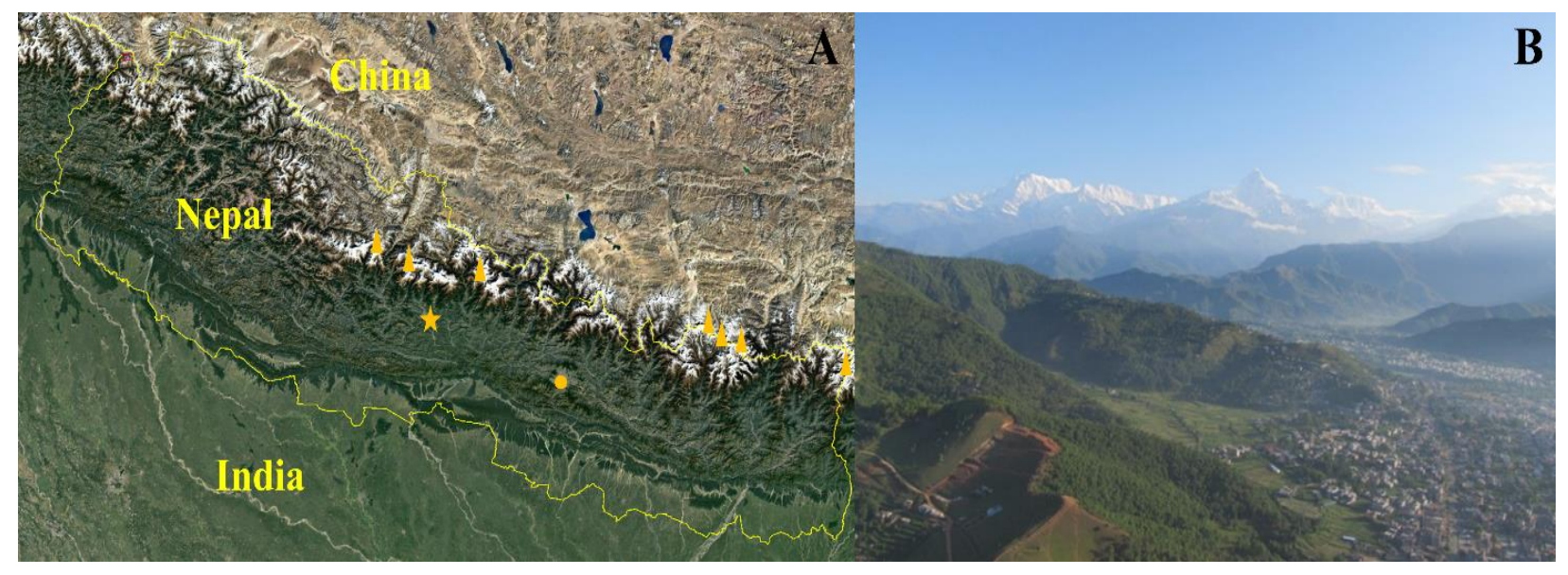

Figure 1. Images depicting (A) the locations of Pokhara (star), Kathmandu (dot), and mountain peaks greater than $8000 \mathrm{~m}$ asl (triangles) and (B) the city of Pokhara and surrounding mountains. 

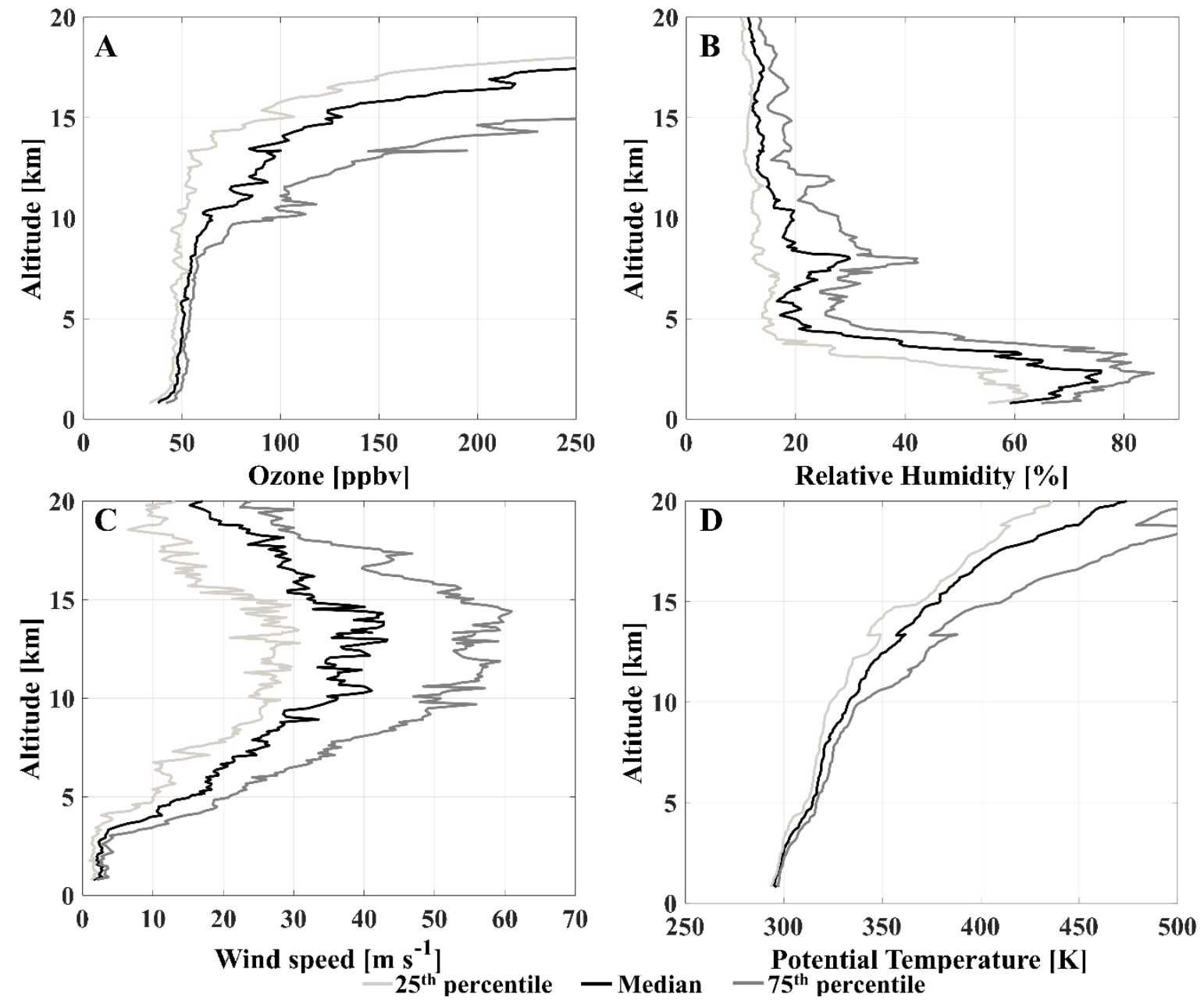

Figure 2. Vertical profiles depicting the $25^{\text {th }}$ (light gray), $50^{\text {th }}$ (black), and $75^{\text {th }}$ percentiles (dark gray) for (A) ozone, (B) relative humidity, (C) wind speed and (D) theta measured by all ozonesondes. 
Table 1. Summary statistics for $\mathrm{O}_{3}, \mathrm{RH}$, temperature and wind speed measured by all ozonesondes $(\mathrm{N}=24)$.

\begin{tabular}{|c|c|c|c|c|c|c|}
\hline Variable & Altitude $[\mathrm{km}]$ & Mean & Median & $\begin{array}{l}\text { Standard } \\
\text { deviation }\end{array}$ & $\begin{array}{c}25^{\text {th }} \\
\text { percentile }\end{array}$ & $\begin{array}{c}75^{\text {th }} \\
\text { percentile }\end{array}$ \\
\hline \multirow{8}{*}{ Ozone [ppb] } & $0-2$ & 44.7 & 45.3 & 5.2 & 41.3 & 48.5 \\
\hline & $2-4$ & 48.7 & 48.4 & 4.5 & 45.6 & 51.6 \\
\hline & $4-6$ & 49.8 & 50.3 & 6.2 & 46.3 & 53.8 \\
\hline & $6-8$ & 54.8 & 53.7 & 50 & 47.4 & 56.4 \\
\hline & $8-10$ & 61.6 & 56.0 & 29.3 & 48.7 & 66.3 \\
\hline & $10-12$ & 65.8 & 58.7 & 20.1 & 50.7 & 85.0 \\
\hline & $12-14$ & 65.1 & 60.6 & 18.6 & 47.6 & 82.8 \\
\hline & 14-16 & 57.1 & 51.6 & 15.8 & 43.8 & 61.8 \\
\hline \multirow{8}{*}{ RH [\%] } & $0-2$ & 66.4 & 67.8 & 12.8 & 59.8 & 74.9 \\
\hline & $2-4$ & 56.6 & 61.4 & 24.7 & 38.6 & 78.2 \\
\hline & 4-6 & 25.7 & 21.0 & 15.9 & 14.6 & 30.8 \\
\hline & $6-8$ & 24.9 & 22.1 & 13.4 & 15.5 & 29.9 \\
\hline & $8-10$ & 23.8 & 19.7 & 13.1 & 13.1 & 31.4 \\
\hline & $10-12$ & 20.6 & 15.9 & 12.7 & 12.6 & 24.5 \\
\hline & $12-14$ & 16.3 & 13.4 & 8.17 & 11.1 & 18.6 \\
\hline & 14-16 & 15.5 & 12.7 & 6.6 & 11.4 & 16.1 \\
\hline \multirow{8}{*}{ Theta [K] } & $0-2$ & 296.8 & 297.2 & 1.87 & 295.2 & 298.2 \\
\hline & $2-4$ & 303.1 & 301.1 & 5.4 & 299.5 & 305.5 \\
\hline & 4-6 & 313.6 & 314.4 & 6.4 & 309.5 & 317.3 \\
\hline & $6-8$ & $\mathbf{3 2 7 . 8}$ & 319.2 & 56.1 & 316.4 & 324.7 \\
\hline & $8-10$ & 333.1 & 326.9 & 41.5 & 320.4 & 333.1 \\
\hline & $10-12$ & 367.8 & 339.2 & 44.47 & 328.9 & 354.9 \\
\hline & $12-14$ & 381.8 & 356.4 & 104.4 & 342.8 & 374.7 \\
\hline & $14-16$ & 383.6 & 378.6 & 51.7 & 361.5 & 399.8 \\
\hline \multirow{8}{*}{ Wind speed $\left[\mathrm{ms}^{-1}\right]$} & $0-2$ & 2.4 & 2.3 & 1.02 & 1.6 & 3 \\
\hline & $2-4$ & 4.8 & 3.1 & 1.5 & 1.8 & 5.6 \\
\hline & 4-6 & 14.9 & 14.2 & 8.7 & 8.7 & 20.5 \\
\hline & $6-8$ & 22.4 & 21.9 & 13.7 & 12.1 & 30.7 \\
\hline & 8-10 & 31.9 & 29.1 & 14.5 & 22.9 & 42.9 \\
\hline & $10-12$ & 37.3 & 34.8 & 18.2 & 25.1 & 52.9 \\
\hline & $12-14$ & 39.5 & 37.4 & 18.8 & 37.4 & 52.9 \\
\hline & $14-16$ & 35.9 & 31.5 & 18 & 22.9 & 52.8 \\
\hline
\end{tabular}




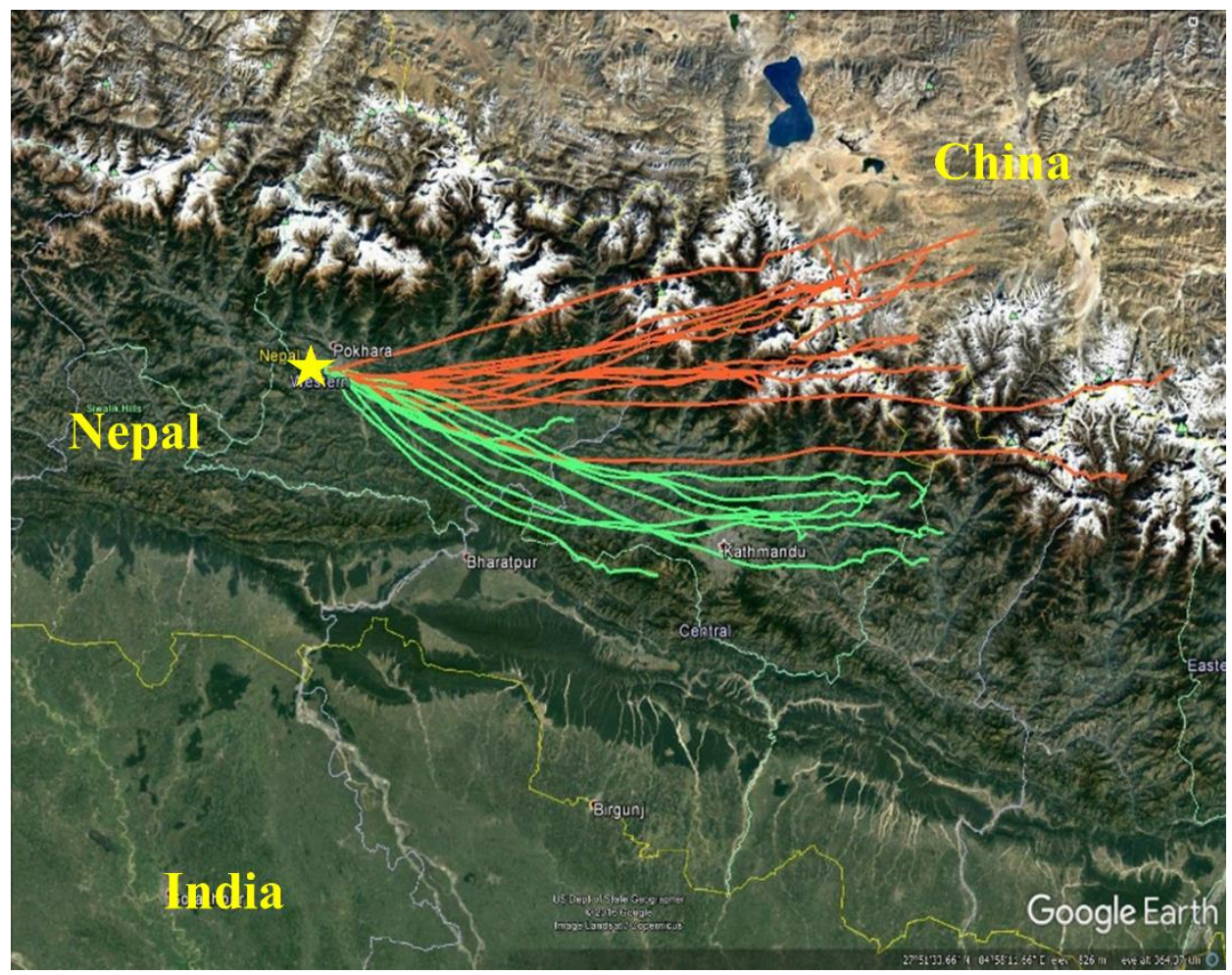

Figure 3. Ozonesonde flight paths from Pokhara (starred) color coded by those that crossed or were over the Himalayan range (in orange) and those that stayed south of the range (in green). 

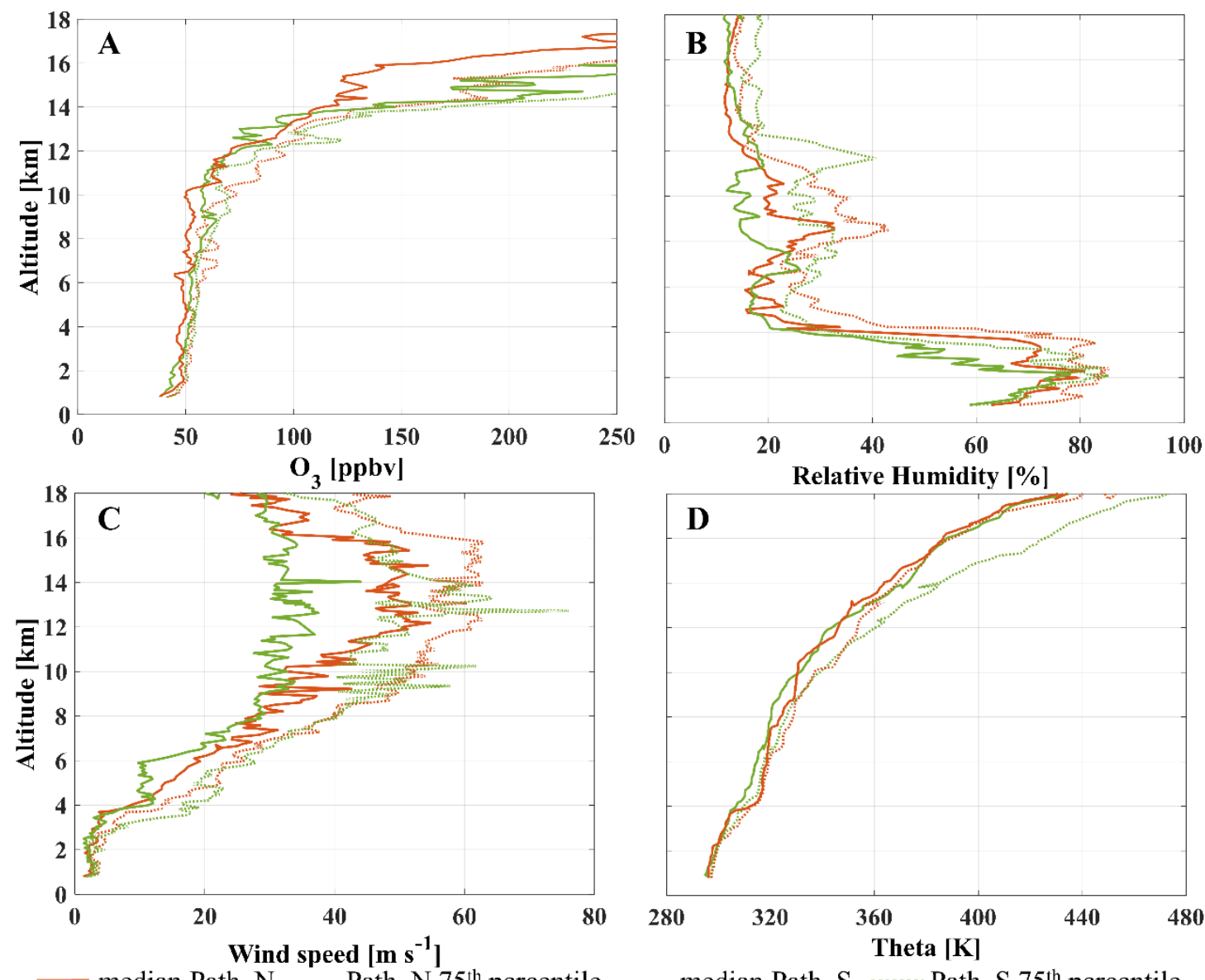

- median Path_N ....... Path_N 75 th percentile — median Path_S ....... Path_S 75 ${ }^{\text {th }}$ percentile

Figure 4. Vertical profiles of median (solid lines) and 75th percentiles (dotted lines) for (A) ozone, (B) RH, (C) wind speed, and (D) theta measured by ozonesondes that crossed or were over the Himalayan range (orange) and those that were south of the range (green). 

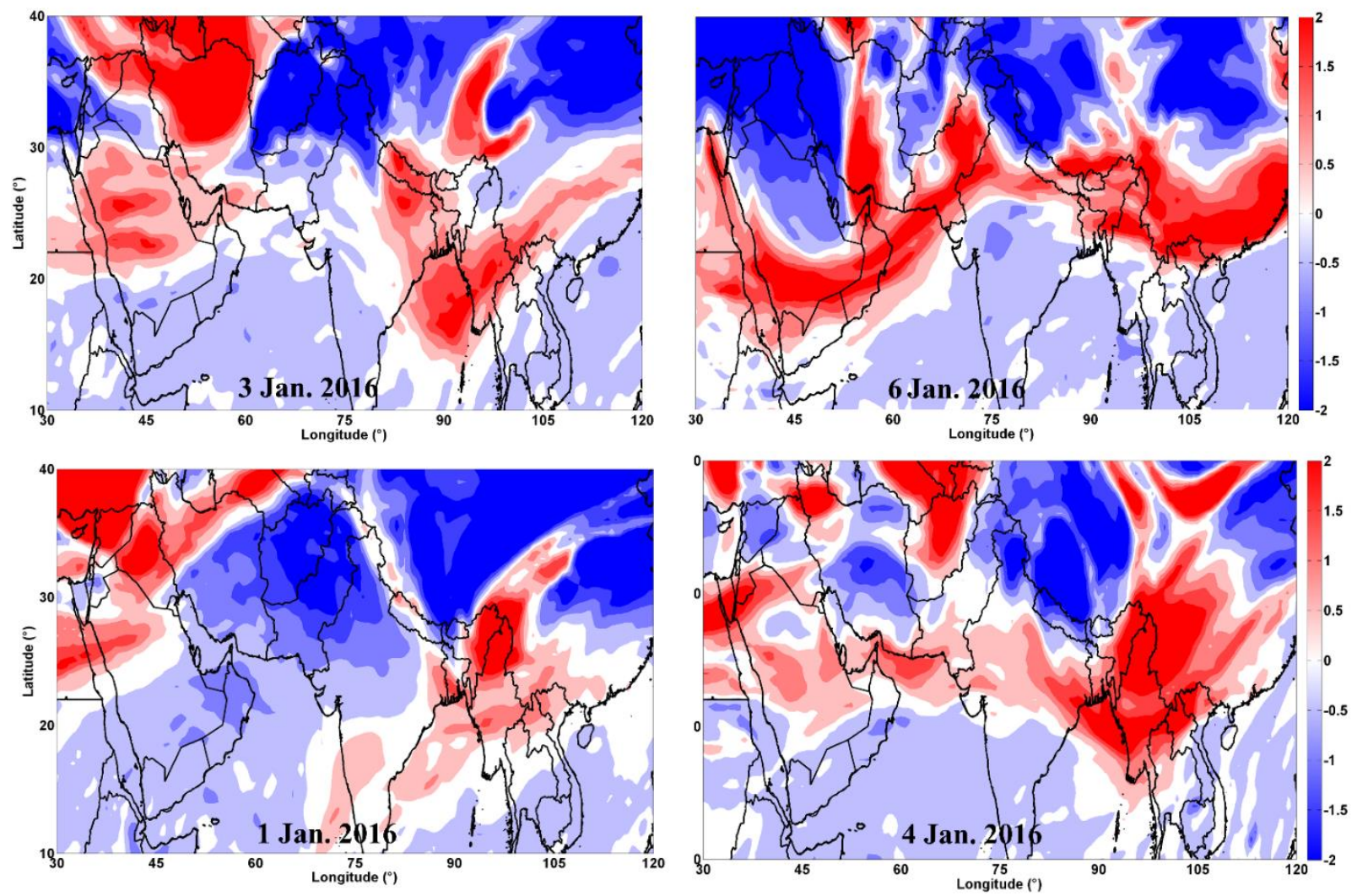

Figure 5. PV maps from MERRA-2 showing positive (red) and negative (blue) anomalies over Pokhara (star). 

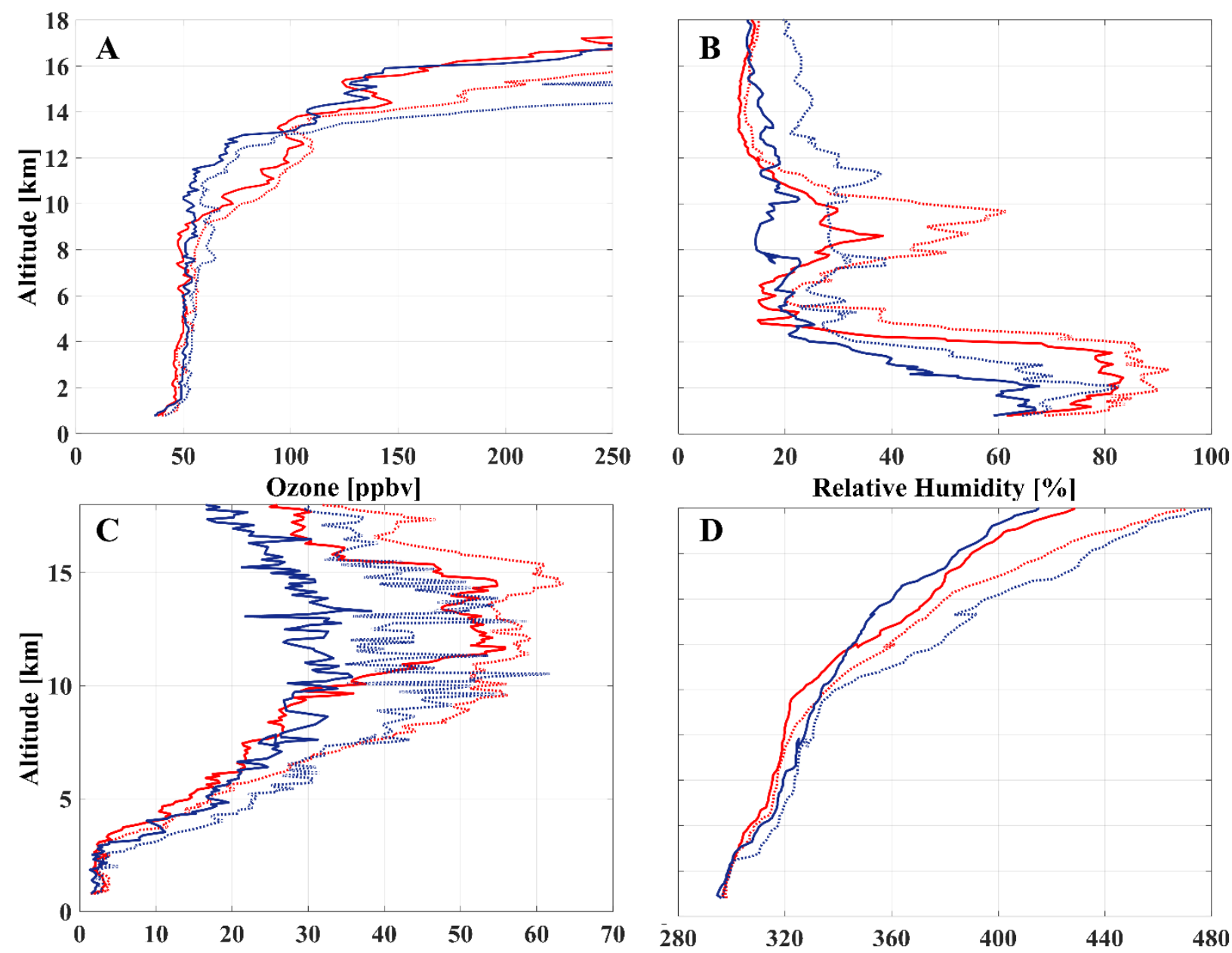

Wind speed $\left[\mathrm{m} \mathrm{s}^{-1}\right]$

— median High PV …....High PV $75^{\text {th }}$ percentile

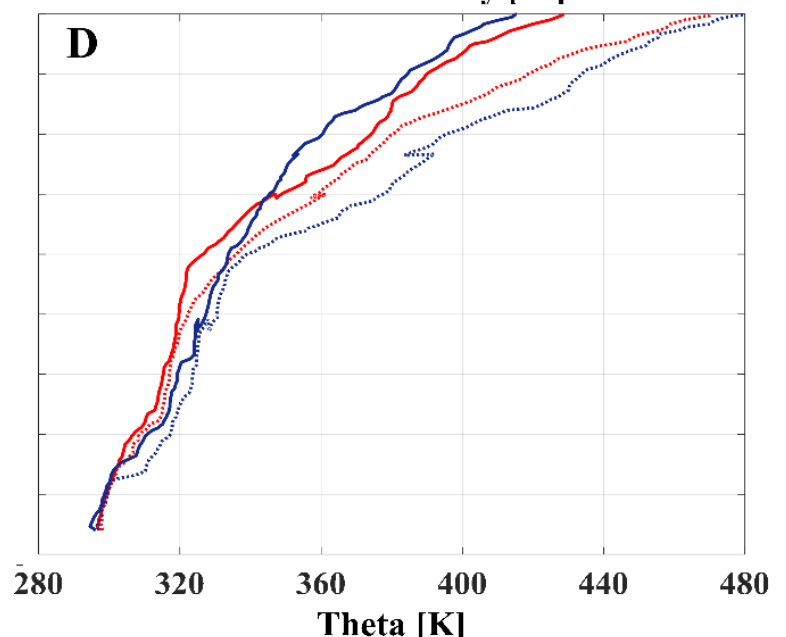

median Low PV …..... Low PV $75^{\text {th }}$ percentile

Figure 6. Vertical profiles of median (solid lines) and $75^{\text {th }}$ percentiles(dotted lines) for (A) O3, (B) RH, (C) wind speed, and (D) theta during periods of high (red) and low (blue) PV. 


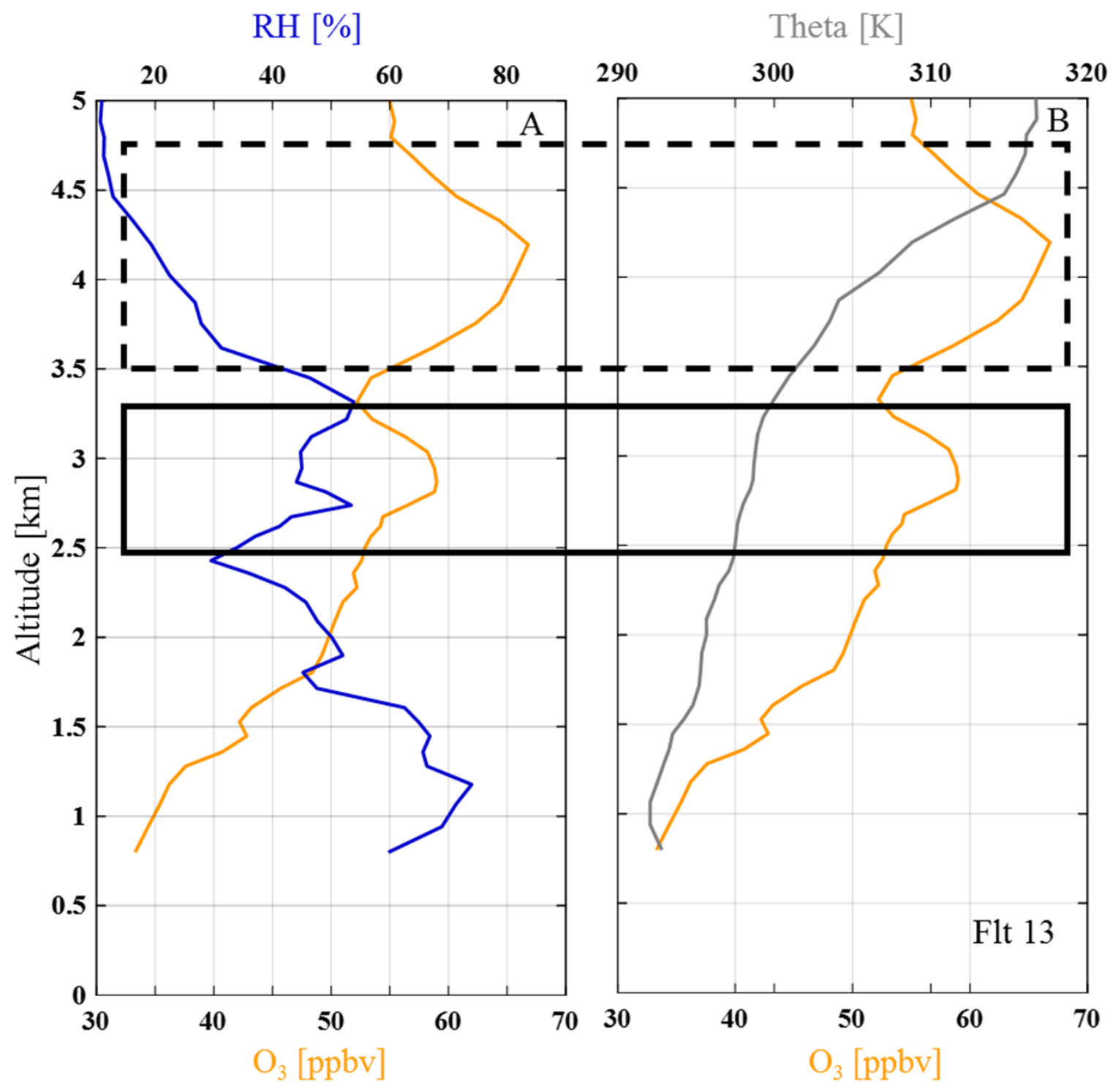

Figure 7. Profiles of (A) $\mathrm{O}_{3}$ and $\mathrm{RH}$ and (B) $\mathrm{O}_{3}$ and theta for Flt13. The dashed and solid boxes show $\mathrm{O}_{3}$ peaks above $75^{\text {th }}$ percentile. 


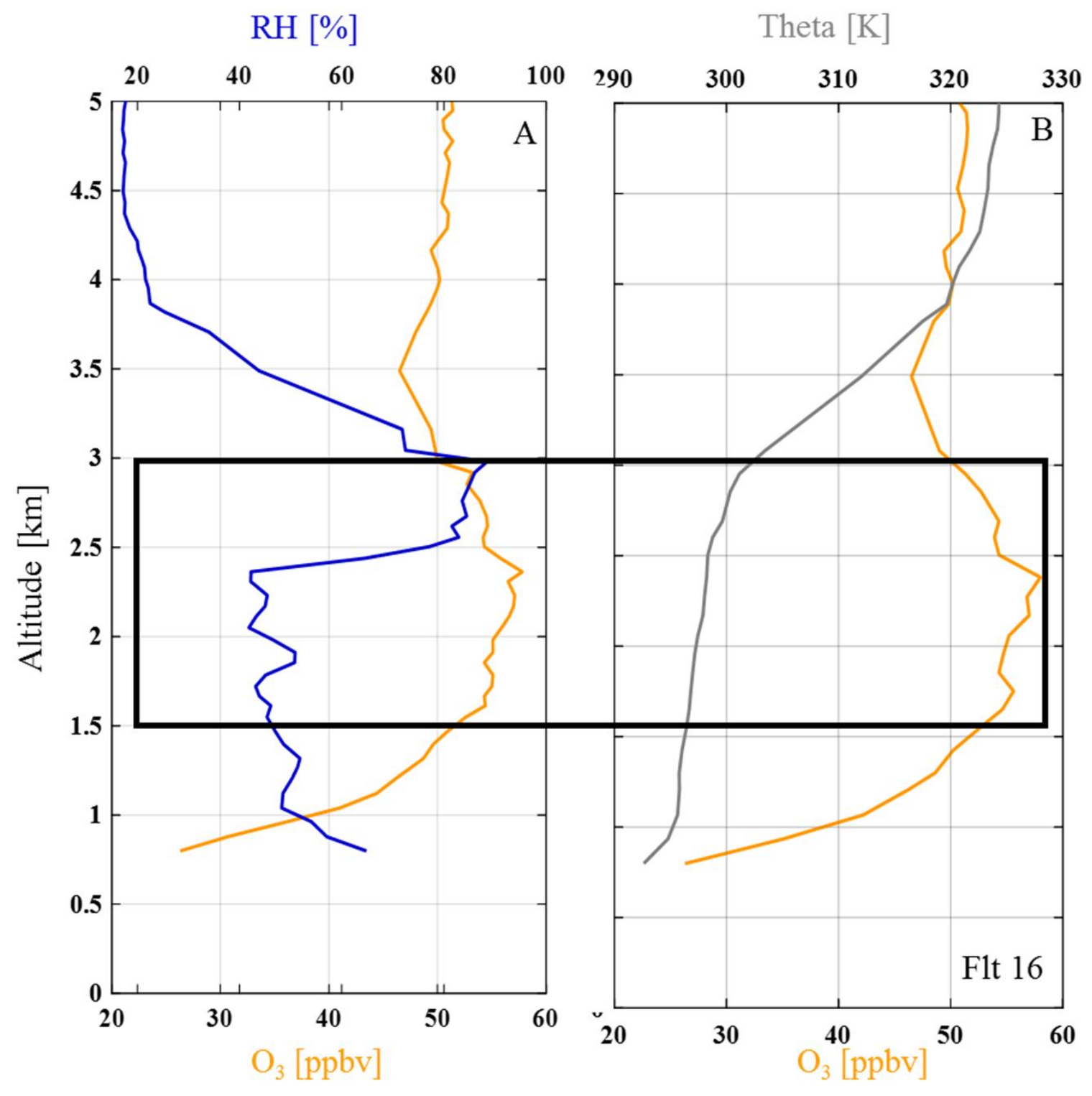

Figure 8. Profiles of (A) $\mathrm{O}_{3}$ and $\mathrm{RH}$ and (B) $\mathrm{O}_{3}$ and theta for Flt16 between surface and $5 \mathrm{~km}$. The solid box shows $\mathrm{O}_{3}$ peak above $75^{\text {th }}$ percentile. 


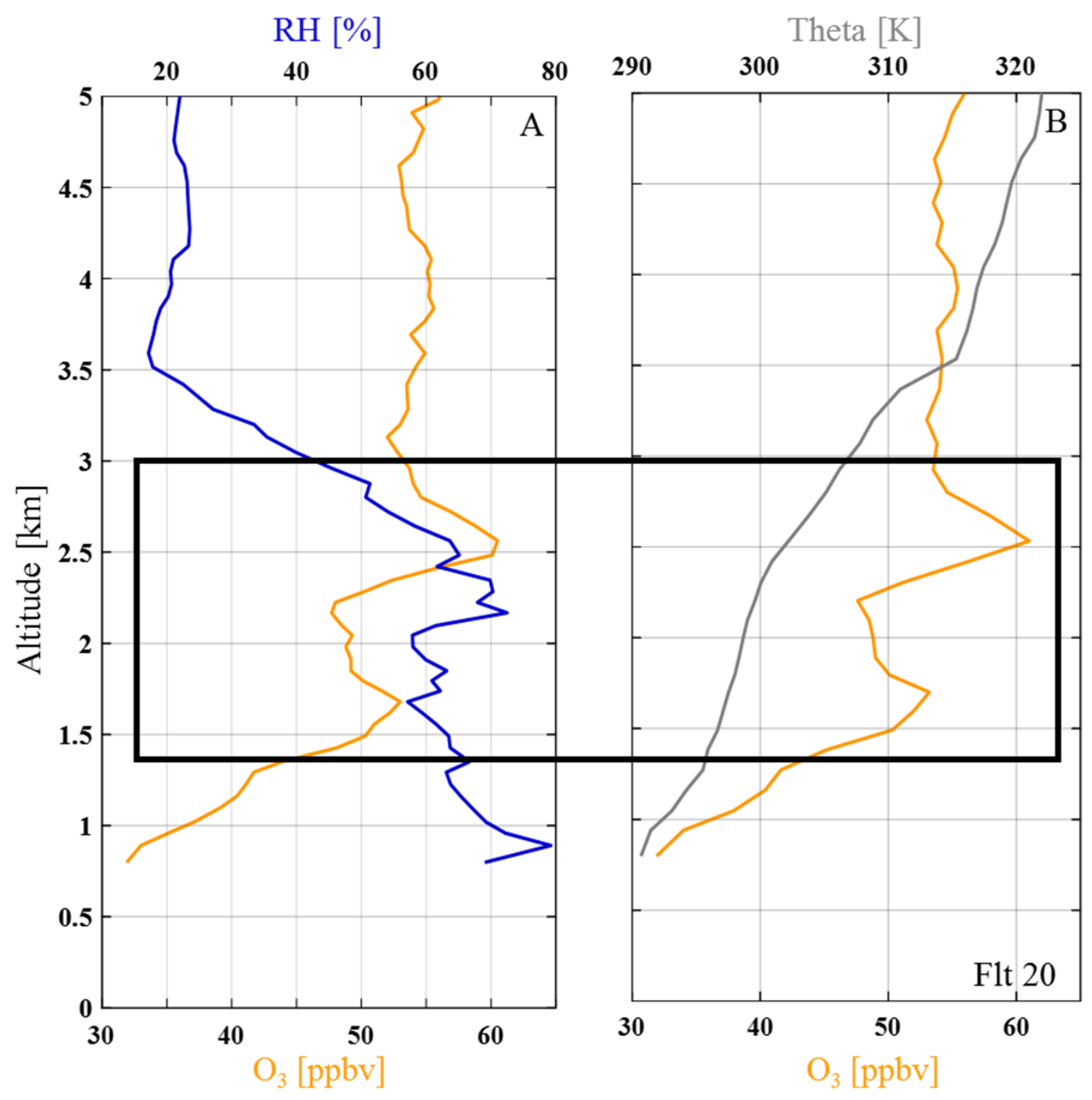

Figure 9. Profiles of (A) $\mathrm{O}_{3}$ and $\mathrm{RH}$ and (B) $\mathrm{O}_{3}$ and theta for Flt20 between surface and $5 \mathrm{~km}$. The solid box shows peak above $75^{\text {th }}$ percentile. 


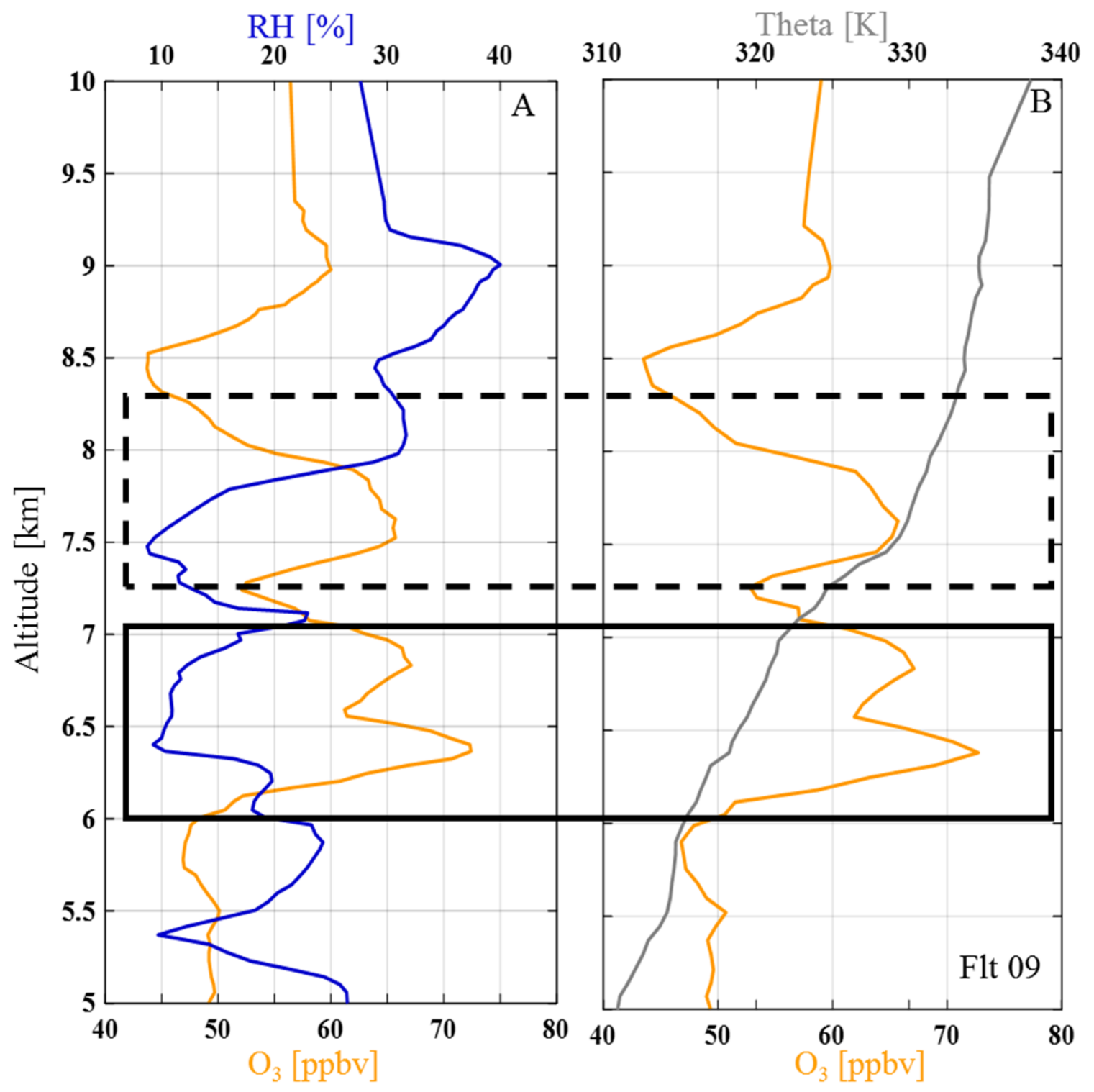

Figure 10. Profiles of (A) $\mathrm{O}_{3}$ and $\mathrm{RH}$ and (B) $\mathrm{O}_{3}$ and theta for Flt09 between surface and $5 \mathrm{~km}$. The solid and dashed boxes show $\mathrm{O}_{3}$ peak above $75^{\text {th }}$ percentile. 


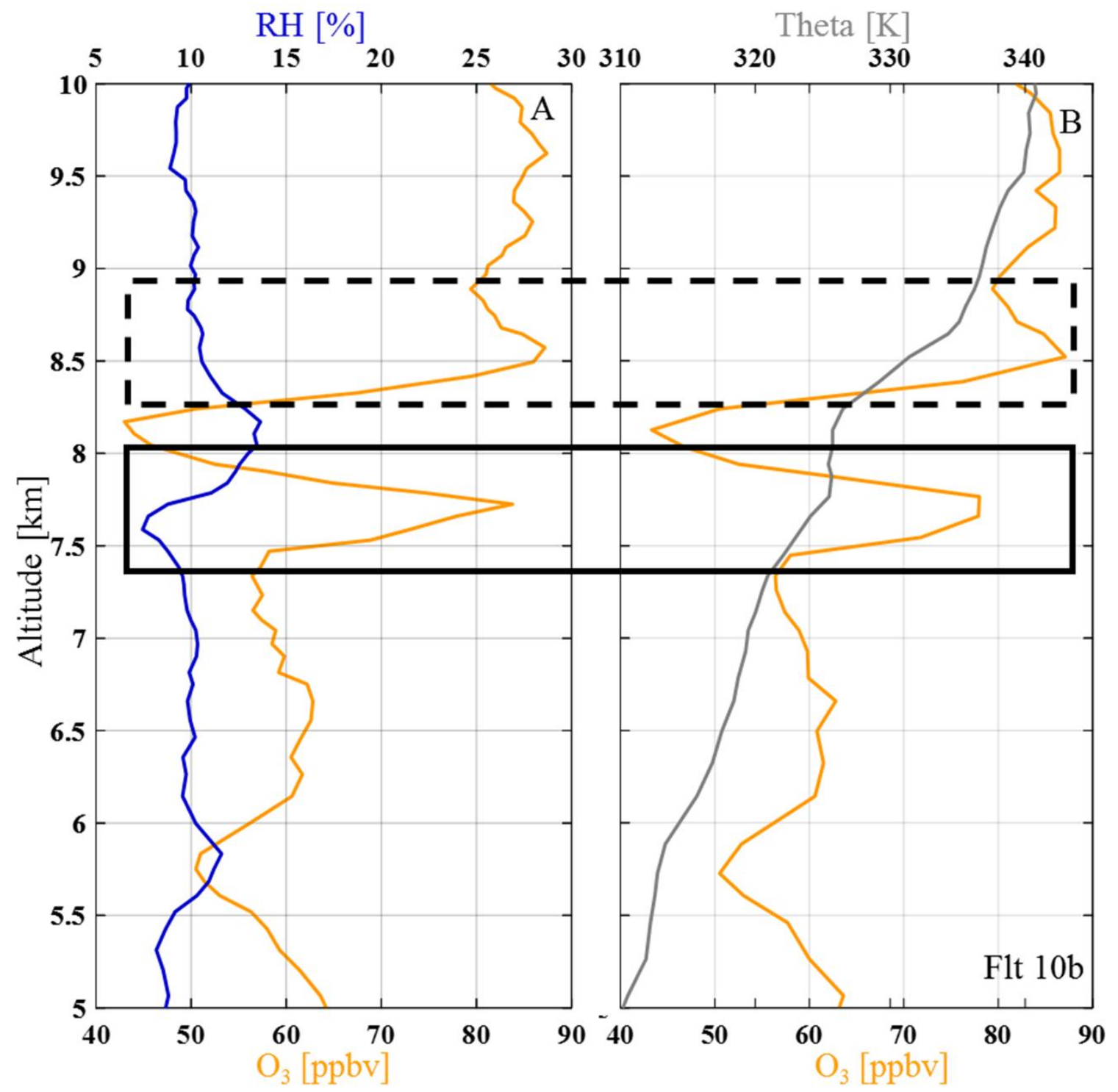

Figure 11. Profiles of (A) $\mathrm{O}_{3}$ and $\mathrm{RH}$ and (B) $\mathrm{O}_{3}$ and theta for Flt10b between $5 \mathrm{~km}$ and $10 \mathrm{~km}$. The solid and dashed boxes show peaks above $75^{\text {th }}$ percentile. 


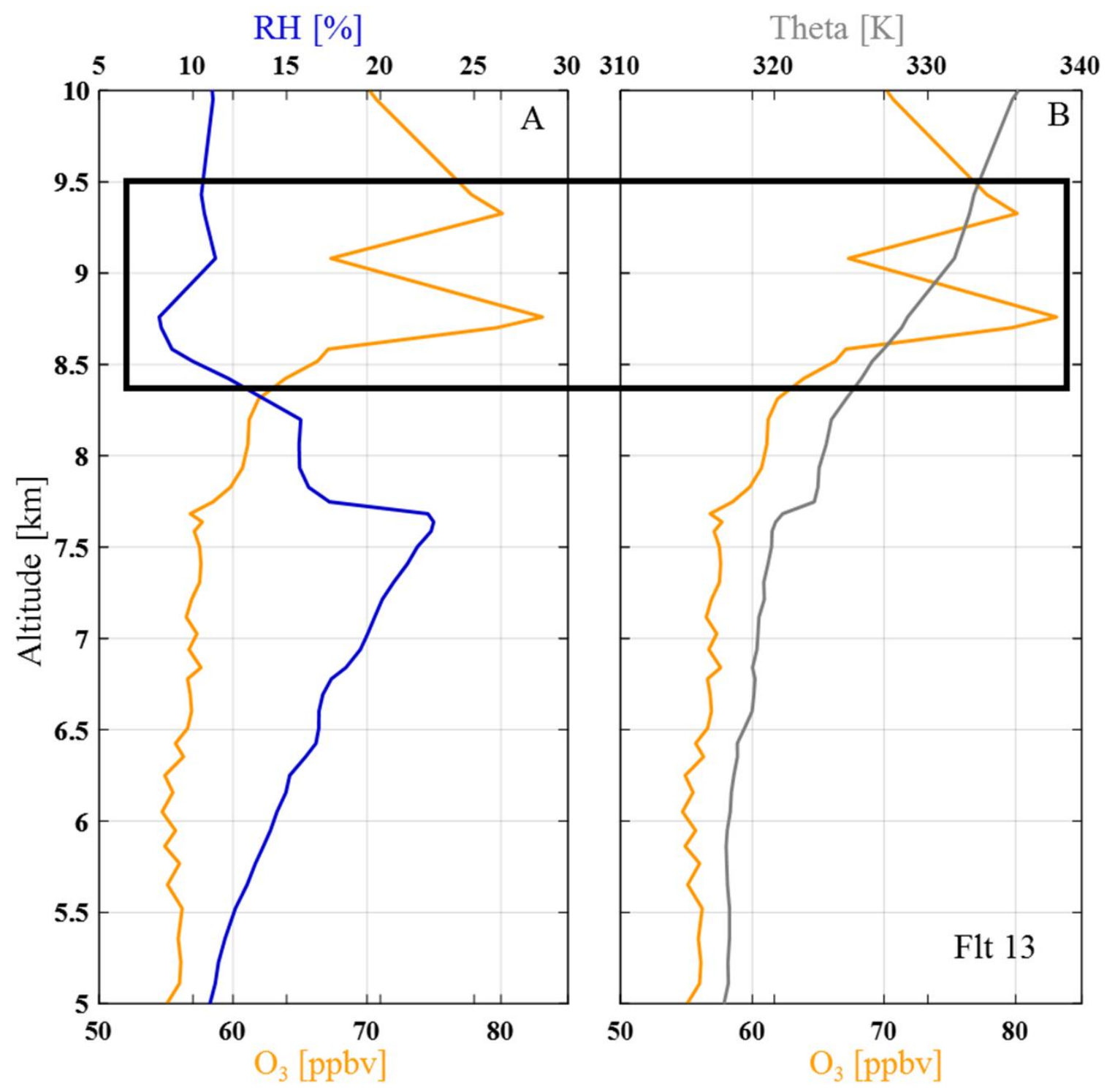

Figure 12. Profiles of (A) $\mathrm{O}_{3}$ and $\mathrm{RH}$ and (B) $\mathrm{O}_{3}$ and theta for Flt13 between $5 \mathrm{~km}$ and $10 \mathrm{~km}$. The solid box shows peak above $75^{\text {th }}$ percentile. 


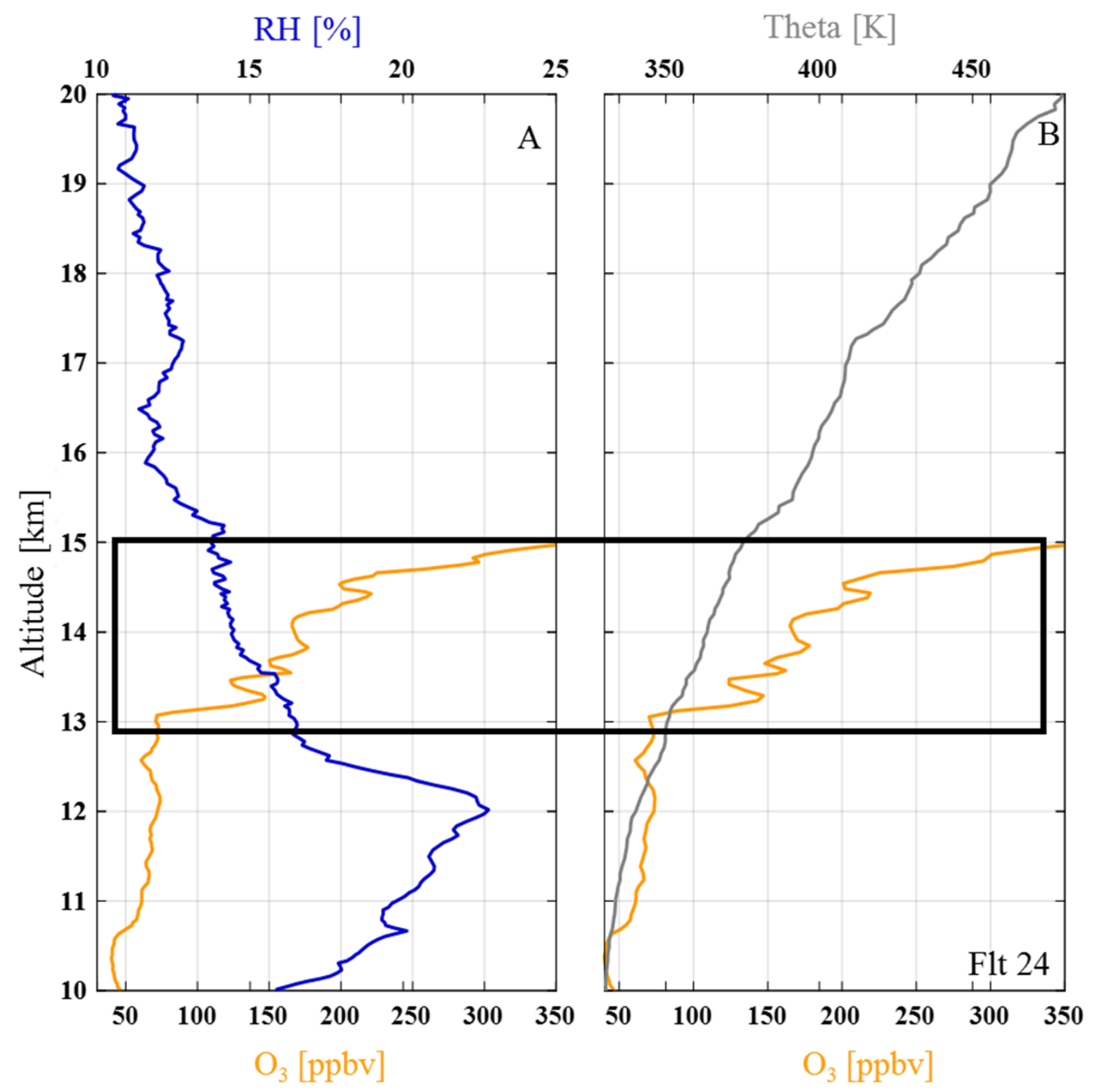

Figure 13. Profiles of (A) $\mathrm{O}_{3}$ and $\mathrm{RH}$ and (B) $\mathrm{O}_{3}$ and theta for Flt24 between $10 \mathrm{~km}$ and $20 \mathrm{~km}$. The solid box shows peak above $75^{\text {th }}$ percentile. 


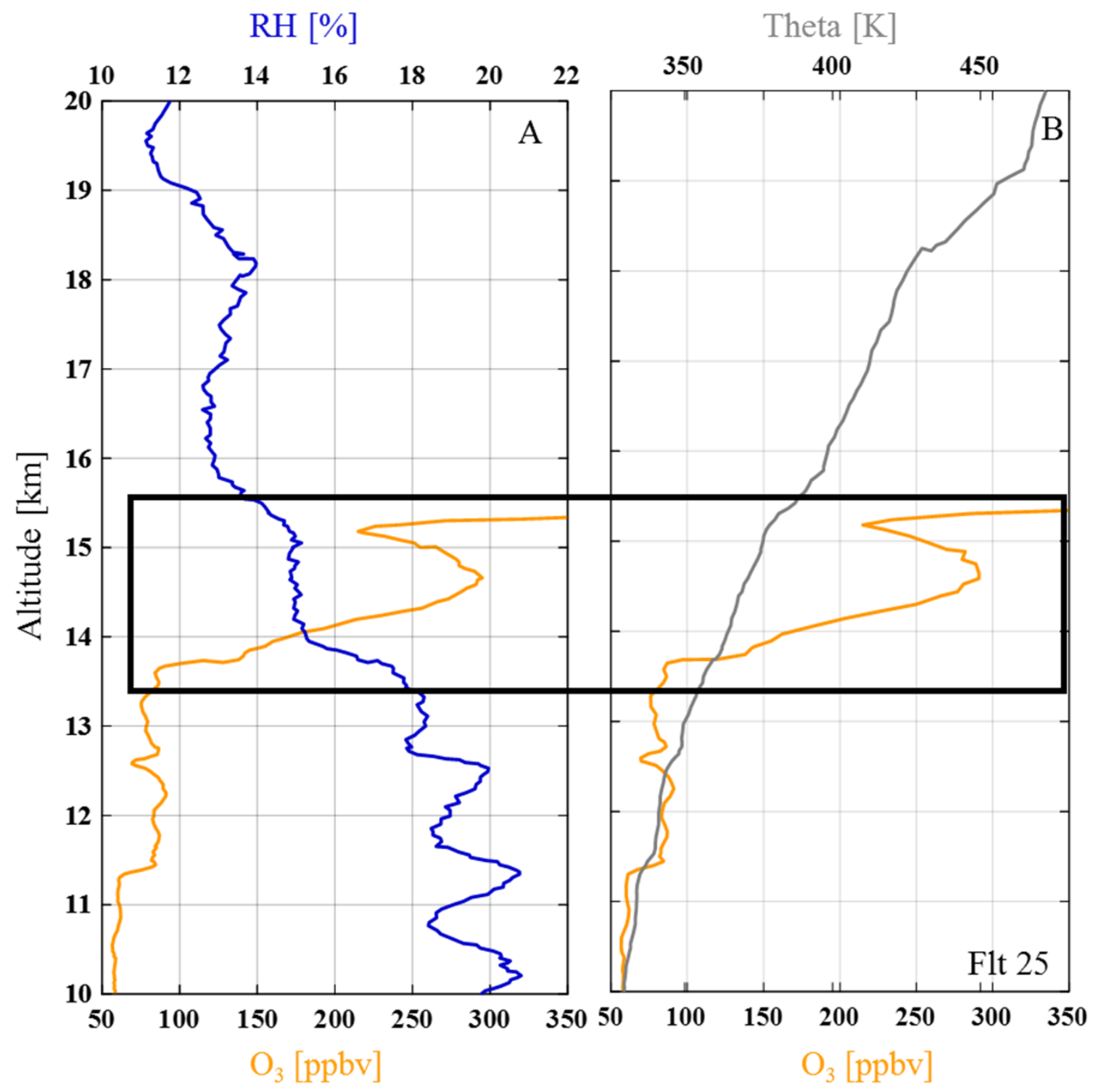

Figure 14. Profiles of (A) $\mathrm{O}_{3}$ and $\mathrm{RH}$ and (B) $\mathrm{O}_{3}$ and theta for Flt25 between $10 \mathrm{~km}$ and $20 \mathrm{~km}$. The solid box shows peak above $75^{\text {th }}$ percentile. 


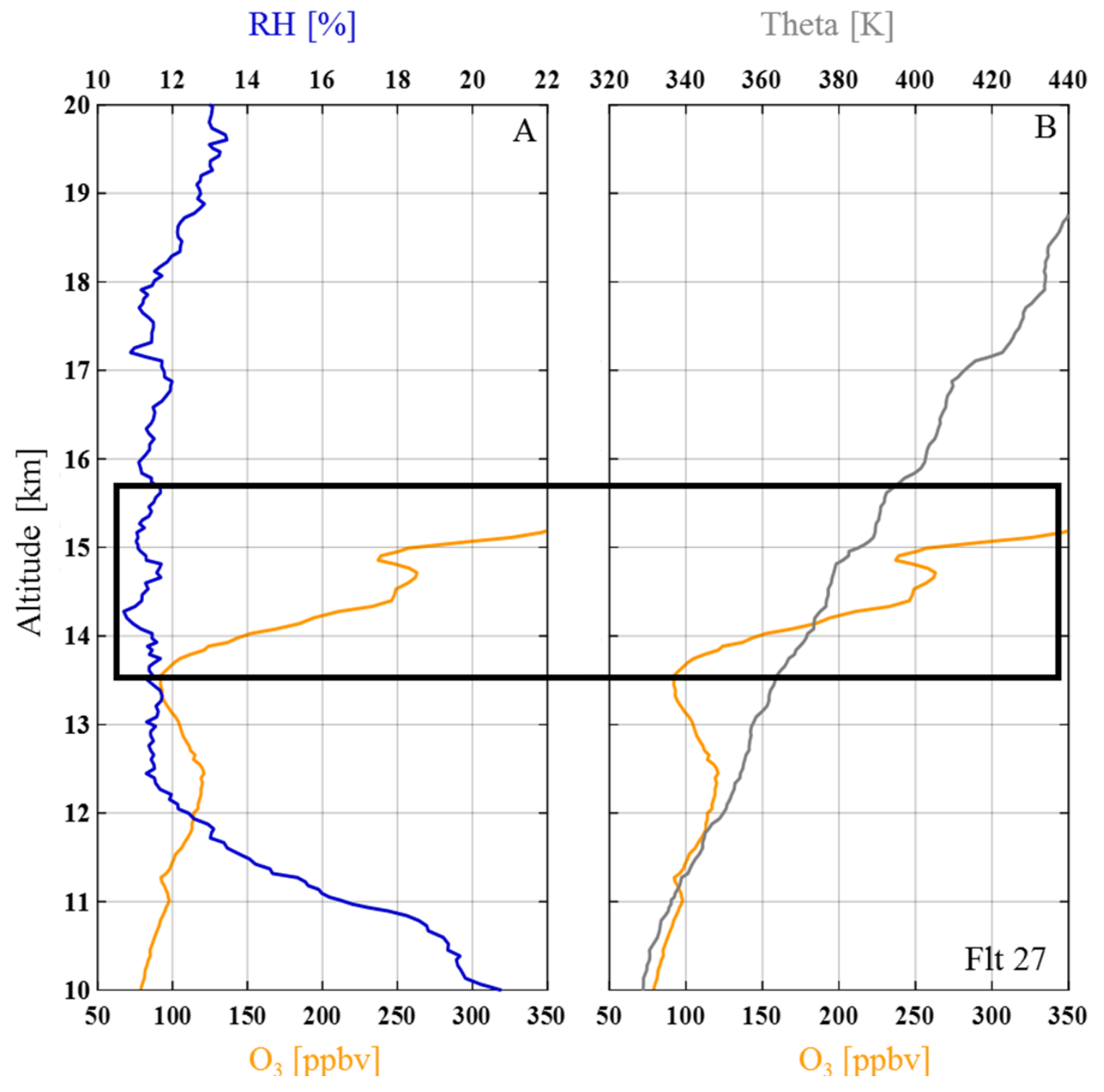

Figure 15. Profiles of (A) $\mathrm{O}_{3}$ and $\mathrm{RH}$ and (B) $\mathrm{O}_{3}$ and theta for Flt27 between $10 \mathrm{~km}$ and $20 \mathrm{~km}$. The solid box shows peak above $75^{\text {th }}$ percentile. 


\section{$\underline{\text { Supplementary materials }}$}

Supplementary Table 1. Ozonesondes launch dates and times (local time is GMT +5 hours 45 minutes). Flights with $(*)$ were omitted in path based analysis as they did not have GPS data while (+) were omitted from all analysis due to incomplete data.

\begin{tabular}{|c|c|c|}
\hline \multirow{2}{*}{ Flight no. } & \multirow{2}{*}{ Date of Launch } & Time of launch \\
\hline & & GMT \\
\hline 002 & 18 Dec. 2015 & 0915 \\
\hline 004 & 19 Dec. & 0639 \\
\hline 005 & 19 Dec. & 1049 \\
\hline $008^{+}$ & 22 Dec. & 0707 \\
\hline 009 & 22 Dec. & 1139 \\
\hline $\mathbf{0 1 0 A}^{+}$ & 23 Dec. & 0632 \\
\hline 010B & 24 Dec. & 0656 \\
\hline $011^{+}$ & 24 Dec. & 1140 \\
\hline 013 & 25 Dec. & 0633 \\
\hline 014 & 25 Dec. & 1154 \\
\hline $016^{*}$ & 26 Dec. & 1135 \\
\hline 017 & 27 Dec. & 0806 \\
\hline 018 & 28 Dec. & 0635 \\
\hline $\mathbf{0 2 0}$ & 29 Dec. & 0421 \\
\hline 022 & 30 Dec. & 0431 \\
\hline 023 & 30 Dec. & 0816 \\
\hline 024 & 2 Jan. 2016 & 0731 \\
\hline 025 & 2 Jan. & 1045 \\
\hline 027 & 3 Jan. & 1027 \\
\hline 028 & 4 Jan. & 0518 \\
\hline 029 & 4 Jan. & 0835 \\
\hline $\mathbf{0 3 0}$ & 5 Jan. & 0838 \\
\hline 031 & 6 Jan. & 0458 \\
\hline 032 & 6 Jan. & 0820 \\
\hline $033^{*}$ & 7 Jan. & 0300 \\
\hline 034 & 7 Jan. & 0624 \\
\hline 035 & 7 Jan. & 1031 \\
\hline 036 & 8 Jan. & 0649 \\
\hline 037 & 8 Jan. & 0924 \\
\hline
\end{tabular}



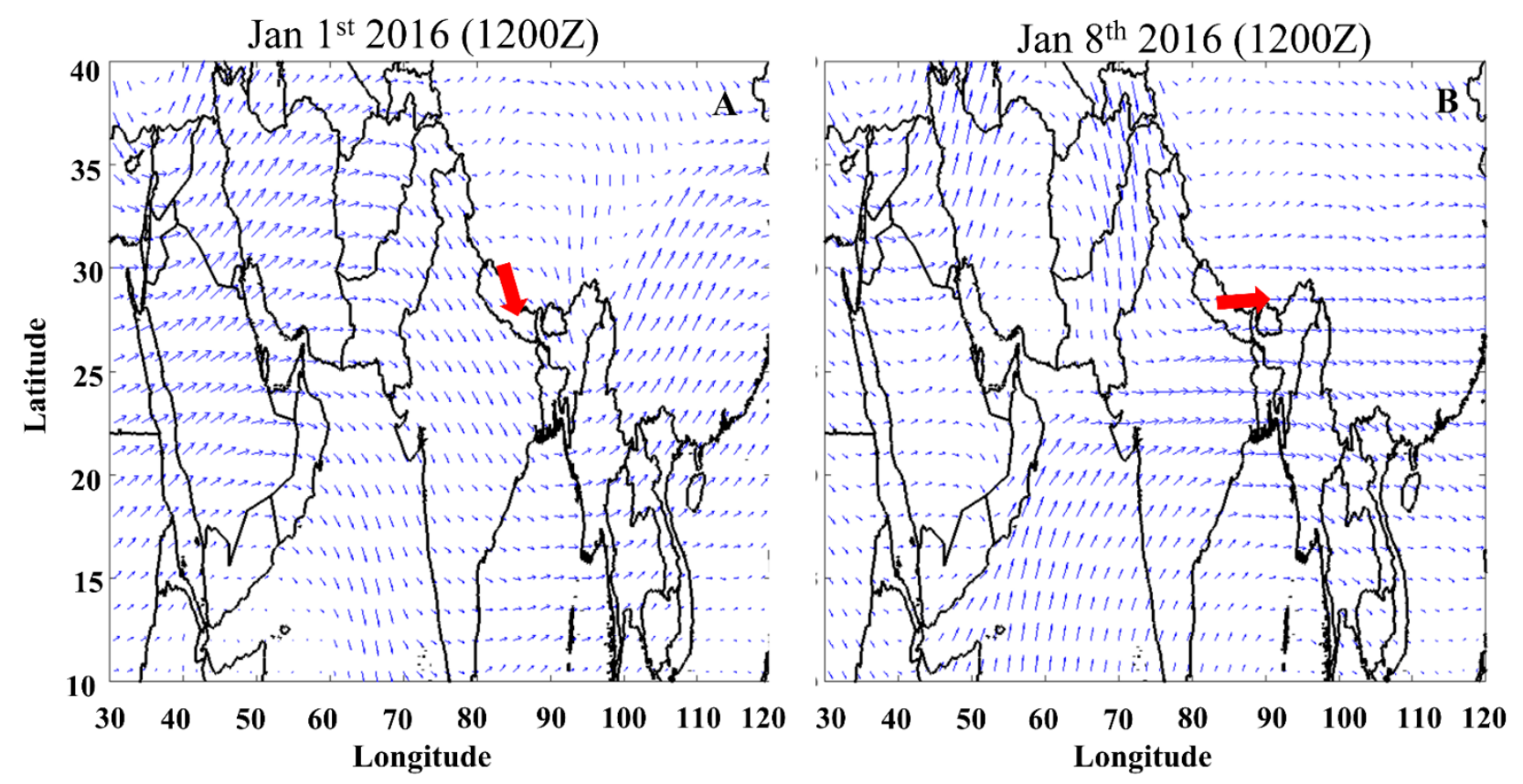

Supplementary Figure 1. The flight paths south of the Himlaya (A) and north of the Himalaya (B) shown with red arrows on $250 \mathrm{hPa}$ wind maps from MERRA-2. 

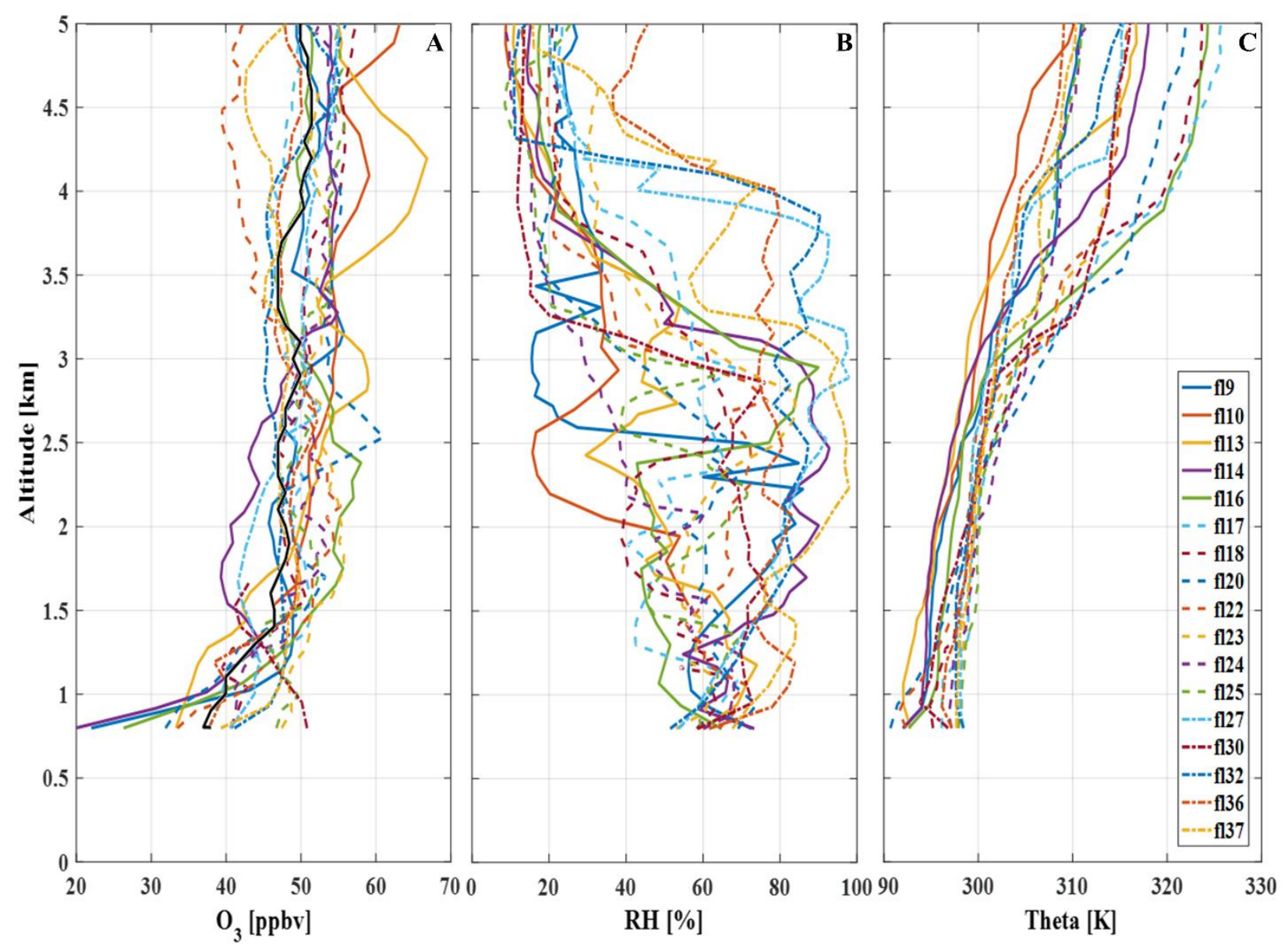

Supplementary Figure 2. Profiles of (A) $\mathrm{O}_{3}$, (B) RH, and (C) theta corresponding to $\mathrm{O}_{3}$ concentrations in the lower troposphere (between surface and $5 \mathrm{~km}$ altitude) that were greater than the $50^{\text {th }}$ percentile (shown in black) for all data. 

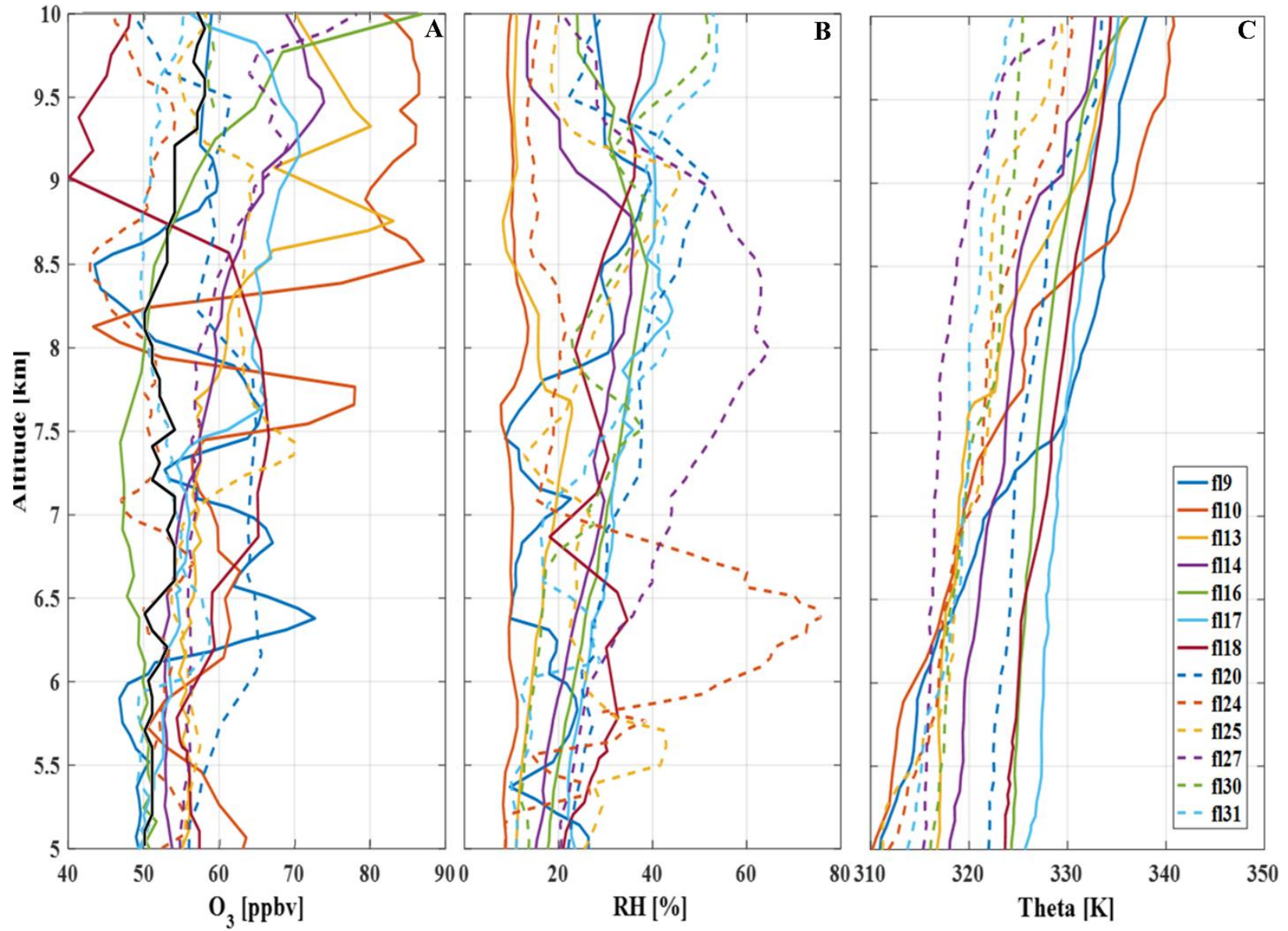

Supplementary Figure 3. Profiles of (A) $\mathrm{O}_{3}$, (B) $\mathrm{RH}$, and (C) theta corresponding to $\mathrm{O}_{3}$ concentrations in the mid troposphere (between 5 and $10 \mathrm{~km}$ altitude) that were greater than the $50^{\text {th }}$ percentile (shown in black) for all data 

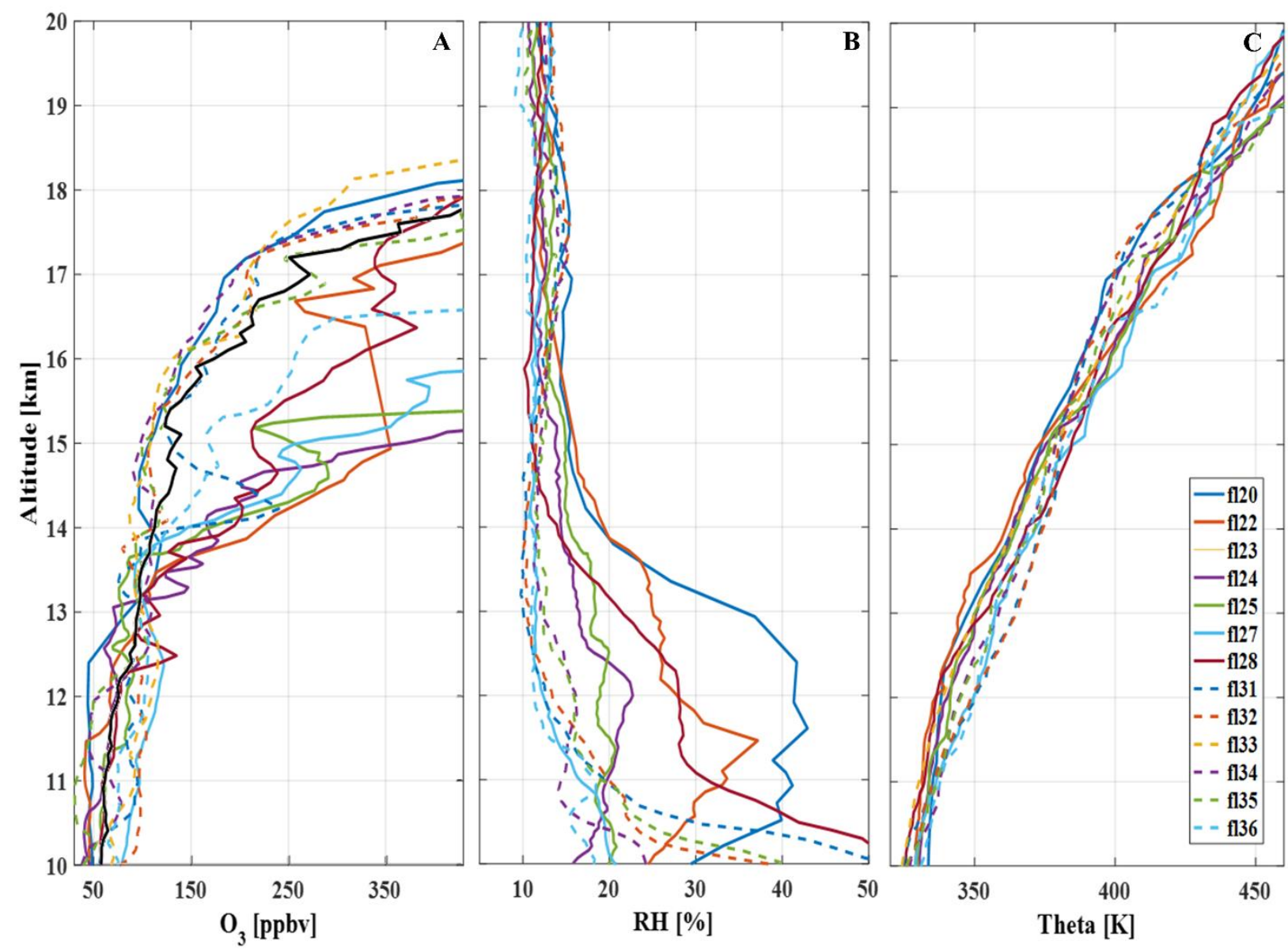

Supplementary Figure 4. Profiles of (A) $\mathrm{O}_{3}$, (B) $\mathrm{RH}$, and (C) theta corresponding to $\mathrm{O}_{3}$ concentrations in the upper troposphere (between 10 and $20 \mathrm{~km}$ altitude) that were greater than the $50^{\text {th }}$ percentile (shown in black) for all data. 


\section{CHAPTER 4. DYNAMIC FACTORS THAT MODULATE STRATOPHERIC CONTRIBUTIONS TO TROPOSPHERIC OZONE OVER THE HIMALAYAN REGION DURING WINTER}

\section{$\underline{\text { Abstract }}$}

The major sources of tropospheric ozone $\left(\mathrm{O}_{3}\right)$ are photochemical reactions involving hydrocarbons, carbon monoxide, and nitrogen oxides and transport from the stratosphere. During frontal passages and below jet streams, a fold can be created in the tropopause due to the sinking of stratospheric air. These tropopause folding events, can inject stratospheric air into the troposphere often forming long streamers of $\mathrm{O}_{3}$ rich, dry air. This process contributes significantly to background tropospheric $\mathrm{O}_{3}$ in the free troposphere. Ozonesonde profiles were evaluated in conjunction with Modern-Era Retrospective analysis for Research and Applications, version 2 (MERRA-2) to investigate stratospheric contributions to tropospheric $\mathrm{O}_{3}$ in the Himalaya region. Low relative humidity and stable potential temperatures over the Tibetan plateau during winter facilitate the downward transport of $\mathrm{O}_{3}$ rich dry eddies driven by the subtropical westerly jet (SJS). Topography induced thermal structure over the Tibetan plateau, during winter, creates a steep gradient along its northern and southern slopes. When the SJS was positioned south of the thermal gradient and the Himalayan range, $\mathrm{O}_{3}$ concentrations above 10 $\mathrm{km}$ altitude south of the Himalaya increased rapidly with increasing altitude. Topography, thermal structure, and the position and strength of the SJS were found to be important interrelated factors in modulating the transport of stratospheric $\mathrm{O}_{3}$ into the troposphere in the Himalayan region.

\section{Introduction}

Tropospheric ozone $\left(\mathrm{O}_{3}\right)$ is a short-lived climate pollutant that warms the atmosphere via radiative heating. Sources of tropospheric $\mathrm{O}_{3}$ include photochemical oxidation of hydrocarbons with nitrogen oxides and transport from the stratosphere. During adiabatic transport (i.e., no transfer of heat) theta and PV are conserved. Globally, isentropic transport to the extratropics occurs in the stratosphere (at long time scales) (Waugh et al., 2006) along with downward mass flux via stratosphere-troposphere exchange (STE) in the middle and high latitudes (Holton et al., 
1995). The mass flux of ozone from the stratosphere to the troposphere ranges from $2.3 \times 10^{17} \mathrm{~kg}$ $\mathrm{yr}^{-1}$ (Reiter et al., 1975) to $3.8 \times 10^{17} \mathrm{~kg} \mathrm{yr}^{-1}$ (Appenzeller et al., 1996). Stratospheric air is characteristically dry and contains high $\mathrm{O}_{3}$ concentrations (Stohl et al., 2000). To a first approximation, dry air masses move along isentropic surfaces (lines of equal potential temperature) in the atmosphere. During frontal passages and below jet streams, a fold can be created in the tropopause due to the adiabatic subsidence of stratospheric air. Strong thermal gradients create isentropic surfaces with steep slopes (relative to altitude). These isentropic gradients exists along the polar front where airmasses of different thermal characteristics meet. In the upper troposphere, there are isentropic gradients around the subtropical jet stream (SJS). Tropopause folding and STE allow air from the stratosphere to enter the troposphere often forming long streamers of $\mathrm{O}_{3}$ rich, dry air. Tropopause folding and subsequent cut-off low formation inject stratospheric air into the free troposphere, which can be mixed to the surface via fronts or high pressure systems (Bonasoni et al., 1999; Davies and Schuepbach, 1994; Cooper et al., 2001). They can be quasi-adiabatically mixed by the large-scale synoptic weather patterns and completely diluted in tropospheric air over time (Stohl et al., 2000). Increases in tropospheric $\mathrm{O}_{3}$ as a result of stratospheric intrusion are not limited to areas of active tropopause folding but can also be advected downwind. For instance, Stohl (2000) found that the advection of stratospheric air, intruded over Greenland, increased $\mathrm{O}_{3}$ concentrations in the Alps. Dynamical processes related to global-scale circulation patterns are responsible for STE in the mid-latitudes (Stohl et al., 2000). Stratospheric intrusions in the mid- and lower troposphere are controlled primarily by the subsidence of the dry air from mid-latitude cyclones (Cooper et al., 2001). Exchange between the stratosphere and troposphere can occur in both directions but the injection of stratospheric air into the troposphere peaks during spring in the mid-latitudes (Appenzeller et al., 1996). Stratospheric air contributes significantly to background tropospheric $\mathrm{O}_{3}$ concentrations due to its long chemical lifetime (1 to 2 months) in the free troposphere (Liu et al., 1987). Because weak stratospheric intrusions can be difficult to detect via in-situ observations, relative contributions to tropospheric $\mathrm{O}_{3}$ from the stratosphere may be underestimated.

Model calculations indicate that approximately $40 \%$ of tropospheric $\mathrm{O}_{3}$ originates from the stratosphere (Reolofs and Lelieveld, 1997). Mountain summits are frequently influenced by stratospheric intrusions (Reiter et al., 1991) due to their high altitudes (Tsutsumi et al., 1998). 
Low relative humidity (RH), high potential vorticity (PV), and high potential temperature (theta) can be used to detect stratospheric air in the troposphere (e.g., Beekmann et al., 1994; Cristofanelli 2006). Model calculations indicate that stratospheric intrusion events over the Himalaya are most frequent during winter (Putero et al., 2016). Low RH and stable potential temperatures over the Tibetan plateau during winter season can facilitate the downward transport of $\mathrm{O}_{3}$ rich dry eddies (Chen et al., 2013).

In this paper, we compare ozonesondes with model cross sections and illustrate steeply sloping isentropic features are characteristic of strong thermal contrast between the cold, high terrain of the Tibetan plateau and the surrounding plains. The presence of a strong SJS south of the Himalaya along with the geography favoring isentropic subsidence appears to enhance STE in the foothills as observed by our sondes launched from Pokhaara. $\mathrm{O}_{3}$ profiles measured with sondes launched along the southern face of the Himalayan range were interpreted in conjunction with PV, RH, and theta to evaluate potential contributions of the stratosphere to tropospheric $\mathrm{O}_{3}$ in the region. Stratospheric influences were evident in the $\mathrm{O}_{3}$ profiles in mid- and upper troposphere. In this paper, we employ the Modern-Era Retrospective analysis for Research and Applications, version 2 (MERRA-2) reanalysis data to investigate the interrelated influences of topography, thermal structure, and the position and strength of the SJS on the dynamics driving stratosphere-troposphere exchange and associated impacts on tropospheric $\mathrm{O}_{3}$ in the region.

\section{Methods}

Between December 29, 2015 and January 7, 2016, twenty nine ozonesondes were launched from the city of Pokhara $\left(28.12^{\circ} \mathrm{N}, 83.58^{\circ} \mathrm{E}, 800 \mathrm{~m}\right.$ asl, population of 400,000$)$ situated in a valley about $30 \mathrm{~km}$ from the Himalayan range (Fig. 1). One or more of the suite of parameters were not recorded by five of the sondes (e.g., missing global position system) and 10 sondes yielded less than $90 \%$ of complete $\mathrm{O}_{3}$ vertical profiles mostly above $6 \mathrm{~km}$ altitude. The following analysis interprets results for the 14 sondes with greater than $90 \%$ altitudinal coverage for all parameters. Synoptic weather in the region surrounding Pokhara is influenced by oscillation of the subtropical westerly jet (October-May) and the summer monsoon anticyclone (June-September) (Bonasoni, 2010). The maximum temperature in Pokhara ranges from $13.2^{\circ} \mathrm{C}$ in January to 25.5 ${ }^{\circ} \mathrm{C}$ in July-August and the annual rainfall amounts to about $0.37 \mathrm{~m}$ with $80 \%$ of the total annual precipitation occurring from June-September (Khadka and Ramanathan, 2013). The extensive 
haze over Indo-Gangetic plains (IGP) in dry seasons is visible in the valley. MODIS imagery showed haze over IGP throughout the duration of the campaign.

$\mathrm{O}_{3}$ mixing ratios were measured with electrochemical sensors (ECC/EN-SCI model $\left.2 \mathrm{z}\right)$ and ambient pressure, temperature, theta, wind speed (WS), wind direction (WD), and RH was measured in parallel with coupled meteorological radiosondes (i-Met 403MHz GPS). The sondes were flown with $1200 \mathrm{~g}$ rubber balloons and ascended at an average rate of approximately $5 \mathrm{~m} \mathrm{~s}^{-}$

1. The absolute accuracy of $\mathrm{O}_{3}$ mixing ratios greater than $100 \mathrm{ppbv}$ varied as a function of altitude from $\pm 5 \%$ to $\pm 10 \%$ and precision varied from $\pm 3 \%$ to $\pm 5 \%$ (Smith, et al., 2007). Pressure offsets were corrected using the geopotential height and GPS altitude from the radiosonde. Theta, WS, and RH were integrated over 1-s time intervals and $\mathrm{O}_{3}$ was integrated over $100-\mathrm{m}$ altitude intervals. In addition, global PV anomalies were calculated at $250 \mathrm{hPa}$ using Modern-Era Retrospective analysis for research and applications, version 2 (MERRA-2). MERRA-2 provides long-term global reanalysis by assimilating space-based observations of atmospheric aerosol and associated interactions with physical processes and is a product of NASA's Goddard Earth Observation System (GOES-5.12.4) atmospheric data assimilation. The horizontal resolution of the model is $0.5^{\circ} \times 0.625^{\circ}$ in latitude and longitude, respectively, and has 72 levels from the surface to $0.01 \mathrm{hPa}$ with data provided at 3-hour intervals. MERRA-2 uses stratospheric profiles from the Microwave Limb Sounder (MLS) instrument and total ozone column observations from the Ozone Monitoring Instrument (OMI), both on NASA's Earth Observing System Aura (EOS Aura) satellite.

\section{Results}

\section{$\underline{\text { 3.1 Comparison between observations and MERRA-2 }}$}

Seven of the 14 profiles correspond to sondes that were launched during periods of high PV (greater than 1.5) and the other 7 were during periods of lower PV. In addition, 9 of the 14 sondes crossed or remained over the mountain range and the other 5 stayed over the foothills to the south of the range. Six of the 7 sondes launched during high PV were transported over the range whereas 4 of 7 sondes during low PV remained over the foothills. (Supplementary Table 1). 
We compared theta, $\mathrm{RH}$, and wind speed predicted by MERRA-2 with the corresponding in-situ measurements at each elevation. Scatter plots with standard linear regressions for all paired results are depicted in Figure 1. MERRA-2 over predicted RH at most levels in the troposphere as expected based on a reported moist bias (Basilovich et al., 2015). Predicted and measured wind speeds below about $40 \mathrm{~m} \mathrm{~s}^{-1}$ agreed reasonably well but MERRA-2 overestimated higher wind speeds by about 5 to $10 \mathrm{~m} \mathrm{~s}^{-1}$. The generally good agreement between predicted and observed wind speeds allow MERRA-2 to be used with reasonable confidence in evaluating the role of SJS in STE over the Himalaya. Our analysis over this region of the Himalaya also suggests that MERRA-2 has a cold bias. MERRA-2 consistently underestimates theta, with a few notable exceptions of overestimate between $320 \mathrm{~K}$ and $360 \mathrm{~K}$. This cold bias over the Himalayan region may represent a limitation of the coarse representation of the topography in the model, but as noted, it is a significant bias. The elevation of Pokhara is $800 \mathrm{~m}$ asl however in MERRA-2 surface elevation is about $3200 \mathrm{~m}$ asl, surface elevation being about $2400 \mathrm{~m}$ higher may be responsible for the cold bias. $\mathrm{O}_{3}$ profiles predicted by MERRA-2 fell within the $75^{\text {th }}$ percentile distribution profile for $\mathrm{O}_{3}$ measured below $12 \mathrm{~km}$ altitude and near the median profile for measured concentrations at higher altitudes (Fig. 2). The differences between measurements and MERRA-2 relate in part to the fact that MERRA-2 profiles are not based on the flight track of the ozonesondes and are integrated over relatively coarse model grids in complex terrain. The launch site at Pokhara and the closest mountain peak ( $5000 \mathrm{~m}$ asl) fall within the same grid cell.

\subsection{Subtropical westerly jet}

The Himalayan range is a topographic barrier that induces anomalies to the general flow pattern on both regional and hemispheric scales. The orographic effects of the Himalayan range can dampen the magnitude of eastward moving troughs (Academica Sinica, 1958). Schiemann et al. (2008) conducted a 40-year subtropical westerly jet (SJS) climatological study and found that the mean position of the SJS is located south (at approximately $28^{\circ} \mathrm{N}$ ) of the Tibetan Plateau with the highest wind speeds during winter. MERRA-2 indicates that the SJS migrates north and south of the Himalaya with wind speeds ranging from $\sim 30$ to $80 \mathrm{~m} \mathrm{~s}^{-1}$ (Fig. 3). Despite the movement of the SJS, the topography driven regional thermal gradient between the Tibetan plateau and the overlying atmosphere did not vary significantly resulting in a persistent 
isentropic feature contouring the Tibetan plateau with steep thermal gradients on the southern and northern slopes of the Tibetan plateau.

The SJS frequently exhibited multiple cores with maximum wind speed centered in more than one location within the jet. Profiles with enhanced $\mathrm{O}_{3}$ concentrations (greater than $10 \mathrm{ppb}$ ) in the upper troposphere above $10 \mathrm{~km}$ altitude did not vary systematically based on the location of the jet or the number of cores within. However, $\mathrm{O}_{3}$ concentrations above $10 \mathrm{~km}$ were consistently high relative to mean concentrations when the core of a single jet or the north most core of a multiple core SJS was over or south of the strong thermal (theta) gradient over the Himalaya. These positions allowed $\mathrm{O}_{3}$-rich stratospheric air to subside along the isentropic surface. In addition, MERRA-2 showed STE over the Tibetan plateau when the core(s) of the SJS was (were) south of the thermal gradient, regardless of the velocity or structure of the SJS core (Supplementary figures 1-14). For example, on December 22 (Fig. 4), the SJS was located over the Tibetan plateau, north of the thermal gradient, resulting in low $\mathrm{O}_{3}$ concentrations above 10 $\mathrm{km}$. In contrast, on January 6 (Fig. 5), the north-most core of the SJS was over the thermal gradient with relatively high concentrations of $\mathrm{O}_{3}(\sim 100 \mathrm{ppbv}$ ) above $10 \mathrm{~km}$. On January 8 (Fig. 6), the SJS was south of the thermal gradient with high $\mathrm{O}_{3}$ concentration ( $\sim 90 \mathrm{ppbv}$ ) above 8.5 $\mathrm{km}$.

\subsection{Thermal, dynamic, and chemical tropopause}

The diffusion of stratospheric air along the isentropic sloped surfaces occurs in the vicinity of the tropopause break. The tropopause fundamentally marks the boundary between the troposphere and the stratosphere reflected by a change in temperature lapse rate or static stability at the boundary (Randel et al., 2007). However, this boundary, is not well defined near the tropopause break. The tropopause is often defined based on temperature lapse rate (thermal tropopause), PV values (dynamical tropopause) and $\mathrm{O}_{3}$ content (chemical tropopause). World Meteorological Organization (1957) defines the first and second thermal tropopause as follows:

"The first tropopause is the lowest level at which the lapse rate decreases to $2{ }^{\circ} \mathrm{C} / \mathrm{km}$ or less, provided also that the average lapse rate between this level and all higher levels within $2 \mathrm{~km}$ does not exceed $2{ }^{\circ} \mathrm{C} / \mathrm{km}$. 
The second tropopause can be defined using the same criteria as the first tropopause if the average lapse rate at any level above the first tropopause exceeds $3{ }^{\circ} \mathrm{C} / \mathrm{km}$. This tropopause can be within or above the $1 \mathrm{~km}$ layer."

The dynamical tropopause exists at the interface between troposphere and stratosphere where the PV values exceed 1.5 to 3 PVU (Holton et al., 1995). We use 1.5 PVU to mark the dynamical tropopause in profiles launched from Pokhara. A study based on radiosondes, reanalysis data and GPS radio occultation temperature profiles showed that the difference between thermal and dynamical tropopause is most evident near the SJS (Randel et al., 2007). In addition, $\mathrm{O}_{3}$ concentration (100 ppbv) can be used to define a chemical tropopause as a sharp gradient in $\mathrm{O}_{3}$ concentration at the tropopause (e.g. Bethan et. al., 1996, Thouret et al., 1998). Bethan et al. (1996) found that the chemical tropopause was $\sim 2 \mathrm{~km}$ lower than the thermal tropopause for $98 \%$ of the ozonesonde profiles and was more closely related to the dynamic tropopause.

In this study, we distinguished thermal, dynamic and chemical tropopause altitudes for each sonde. We found multiple thermal tropopauses in 4 out of 14 sondes; multiple tropopauses are often found when there is a break in the first thermal tropopause near the SJS (Randel et al., 2006). A characteristic break in the thermal tropopause is indicative of a potential STE. Based on MERRA-2 PV data, the dynamic tropopause was defined at the altitude where PV was higher than 1.5 PVU (Table 1). The chemical tropopause was defined as the lowest altitude with 100 ppbv $\mathrm{O}_{3}$ concentration based on ozonesonde profiles. In general, our results show the chemical tropopause height was in better agreement with the lowest dynamic tropopause than with the lowest thermal tropopause. Lower chemical and (lowest) dynamical tropopause conditions resulted in enhanced $\mathrm{O}_{3}$ concentration in the upper troposphere. These relationships support the hypothesis that STE contributes significantly to $\mathrm{O}_{3}$ in the free troposphere over the Himalayan region. In addition, layers of tropospheric air (under 1.5 PVU) in profiles with multiple thermal and dynamic tropopause illustrate the occurrence of frequently intermixed tropospheric and stratospheric air layers of stratospheric air which further suggests active STE in this region.

\section{Case study: possible tropospheric folding over the Tibetan Plateau}

MERRA-2 data suggest possible tropopause folding over the Tibetan Plateau on January 8. Profiles of $\mathrm{O}_{3}, \mathrm{RH}$ and theta measured earlier in the day indicated a sharp increase in $\mathrm{O}_{3}$ concentrations at about $7.5 \mathrm{~km}$ in association with dry air ( $\mathrm{RH}$ below $20 \%$ ) with theta values 
greater than $320 \mathrm{~K}$ (Fig. 6c). The MERRA-data shows tropopause folding with enhanced $\mathrm{O}_{3}$ concentrations as low as $7 \mathrm{~km}$ (Fig. 6a) along the theta gradient (Fig. 6b). This tropopause folding is still evident about 2.5 hours later (Fig. 7a) in MERRA-2 cross-section and in ozonesonde data (Fig. 7c). In the morning profile (0649 Z), chemical tropopause (100 ppbv) is at around $10 \mathrm{~km}$ however in Figure 7c the chemical tropopause is lower at around $9 \mathrm{~km}$ altitude. These results suggest subsidence of $\mathrm{O}_{3}$-rich stratospheric air. The SJS was located south of the theta gradient. Similar enhancements in $\mathrm{O}_{3}$ concentrations associated with theta values greater than $320 \mathrm{~K}$ and dry air were evident on other days (see Supplementary Figs. 9, 10, 11 and 12). These profiles reveal dynamics similar to those reported over to the northern slopes of the Tibetan Plateau (Chen et al. 2011) and support the hypothesis the position of the SJS relative to thermal gradients plays an important role in modulating STE and associated concentrations of tropospheric $\mathrm{O}_{3}$ over the Himalaya.

Our analysis revealed enhancements in $\mathrm{O}_{3}$ concentrations due to stratospheric influences as low as $7.5 \mathrm{~km}$ altitude. In addition, local katabatic flows (downslope flows) along the mountain slopes, especially at night, may contribute to the downward transport of $\mathrm{O}_{3}$-rich air downwind of the Himalaya.

Global model calculations suggest that the intensities of tropical storms will increase by $2 \%$ to $11 \%$ over the next century in response to projected global warming (Knutson, et al., 2010) while anthropogenic climate change will push SJS towards the pole which will impact the strength and impact of the SJS (Leroy et al., 2006). Based on our analysis, climate induced changes in the position of the SJS would also drive corresponding changes in STE over the Himalaya. Associated modulation of $\mathrm{O}_{3}$ concentrations in the upper free troposphere could result in positive or negative feedbacks in radiative forcing, based on the direction of the shift in SJS in the region.

\section{$\underline{\text { 5. Conclusion }}$}

We investigated influences of the SJS in modulating tropospheric $\mathrm{O}_{3}$ over the Himalaya using MERRA-2 reanalysis data in conjunction with measured profiles of $\mathrm{O}_{3}, \mathrm{RH}$, theta, and wind speed. Results revealed important interrelated factors that drive STE. Key findings are:

- The Tibetan plateau during winter creates a strong thermal gradient resulting in a persistent isentropic surface that contours the plateau. 
- The position, strength, and structure of the SJS varied temporally across the feature of the cold plateau.

- The location of SJS with respect to the thermal gradient along the southern slope appears to modulated STE over the southern foothills of the Himalaya.

- $\mathrm{O}_{3}$ concentrations above $8 \mathrm{~km}$ altitude were consistently higher than median concentrations when the SJS core(s) were over or south of the thermal gradient regardless of the velocity and structure of the SJS.

- The altitude of the dynamic tropopause and chemical tropopause corresponded better to observed $\mathrm{O}_{3}$ enhancements than the thermal tropopause.

- Discrete air masses exhibiting high and low PV were intermixed down to altitudes above $8 \mathrm{~km}$

- Active tropopause folding over the Tibetan plateau resulted in increase in $\mathrm{O}_{3}$ concentrations over the Himalaya to up to $100 \mathrm{ppb}$ as low as $9 \mathrm{~km}$ altitude.

\section{Acknowledgements}

We would like to acknowledge our field assistant in Nepal, Bhogendra Kathayat, Anil Patel, Dipendra Pokhrel, Gupta Bahadur Singh Giri, Mahesh Giri and Manoj who helped us during ozonesonde launch. We would like to thank the staff at Pokhara Airport tower for their cooperation during the launch. Financial support was provided by the National Aeronautics and Space Administration NNX12AC60G, and additional field support was provided by ICIMOD's Atmosphere Initiative. The authors are very thankful for comments from William Keene. 


\section{$\underline{\text { References }}$}

Academica Sinica, On the general circulation over Eastern Asia (III), Tellus, 10, 299-312, 1958.

Appenzeller, C., Holton, J.R., Rosenlof, K.H., Seasonal variation of mass transport across the tropopause. Journal of Geophysical Research 101, 15071-15078, 1996.

Bethan, S., Vaughan, G., and Reid, S. J.: A comparison of ozone and thermal tropopause heights and the impact of tropopause definitions on quantifying the ozone content of the 10 troposphere, Q.J.R. Meteorol. Soc., 122, 929-944, 1996.

Bonasoni, P., Evangelisti, F., Bonafe, U., Ravegnani, F., Calzolari, F., Stohl, A., Tositti, L., Tubertini, O., Colombo, T., Stratospheric ozone intrusion episodes recorded at Mt. Cimone during the VOTALP project: case studies. Atmo-spheric Environment 34, 1355-1365, 1999.

Bosilovich, M. G., et al., MERRA-2: Initial evaluation of the climate. Series on Global Modeling and Data Assimilation Tech. Rep. NASA/TM-2015-104606, Vol. 43, 145 pp, 2015.

Chen X, Ma, Y., Kelder, H., Su, Z., Yang K., On the behaviour of the tropopause folding events over the Tibetan Plateau. Atmos Chem Phys 11: 5113-5122, 2011.

Chen, C., Tian, W. S., Tian, H-Y, Huo, Y., Shu, J.: Vertical distribution of ozone and stratosphere-troposphere exchanges on the northeastern side of Tibetan Plateau. Plateau Meteorology 31 295-303, 2012.

Cooper, O. R., J. L. Moody, D. D. Parrish, M. Trainer, T. B. Ryerson, J. S. Holloway, G. Hübler, F. C. Fehsenfeld, S. J. Oltmans, and M. J. Evans: Trace gas signatures of the airstreams within North Atlantic cyclones: Case studies from the NARE'97 aircraft intensive, J. Geophys. Res., 106(D6), 5437-5456, doi:10.1029/2000JD900574, 2001.

Cristofanelli, P., Bonasoni, P., Tositti, L., Bonafè, U., Calzolari, F., Evangelisti, F., Stohl, A.: A 6-year analysis of stratospheric intrusions and their influence on ozone at Mt. Cimone (2165 m above sea level). Journal of Geophysical Research Atmospheres, 111(3), 1-11, 2006.

Holton, J.R., Haynes, P.H., McIntyre, E.M., Douglass, A.R., Rood, R.B., Pfister, L., Stratosphere-troposphere exchange. Reviews of Geophysics 33, 403-439, 1995. 
Knutson TR, McBride JL, Chan J, Emanuel K, Holland G, Landsea C, Held I, Kossin JP, Srivastava AK, Sugi M.: Tropical cyclones and climate change. Nat Geosci, 3:157-163. doi:10.1038/ ngeo0779. 2010.

Leroy, S. S., Anderson, J. G., Dykema, J. A.: Testing climate models using GPS radio occultation: A sensitivity analysis, J. Geophys. Res., 111, D17105, doi:10.1029/2005JD006145, 2006.

Liu, S.C., Trainer, M., Fehsenfeld, F.C., Parrish, D.D., Williams, E.J., Fahey, D.W., Hubler, G., Murphy, P.C., Ozone production in the rural troposphere and the implications for regional and global ozone distributions. Journal of Geophysical Research 92, 4191-4207, 1987.

Randel, W. J., Seidel, D. J., Pan, L. L.: Observational characteristics of double tropopauses, J. Geophys. Res., 112, D07309, doi:10.1029/2006JD007904, 2007.

Reiter, R.: On the mean daily and seasonal variations of the vertical ozone profiles in the lower troposphere. Atmospheric Environment 25A, 1751-1757, 1991.

Roelofs, G.-J., Lelieveld, J., Model study of the influence of cross-tropopause $\mathrm{O}_{3}$ transports on tropospheric $\mathrm{O}_{3}$ levels. Tellus 49B, 38-55, 1997.

Schiemann, R., Luthi, D., Schar. C. Seasonality and interannual variability of the westerly jet in the Tibetan Plateau region, Journal of Climate, 22, 2940-2958, 2008.

Stohl, A., Spichtinger-Rakowsky N., Bonasoni, P., Feldmann, H., Memmesheimer, M., Scheel, H.E., Trickl, T., Hubener, Ringer, S. W., Mandl, M., The influence of stratospheric intrusions on the alpine ozone ocncentrations. Atmos. Env., 34, 1323-1354, 2000.

Thouret, V., Marenco, A., Nedelec, P., and Grouhel, C.: Ozone climatologies at 9-12 km altitude as seen by the MOZAIC airborne program between September 1994 and August 1996, J. 10 Geophys. Res., 103, 25 653-25 679, 1998.

Waugh, D.W., Seasonal variation of isentropic transport out of the tropical stratosphere. Journal of Geophysical Research 101, 4007- 4023, 1996.

World Meteorological Organization, Meteorology — A three- dimensional science: Second session of the Commission for Aerology, WMO Bulletin, 4, 134-138,1957. 


\section{Figures}
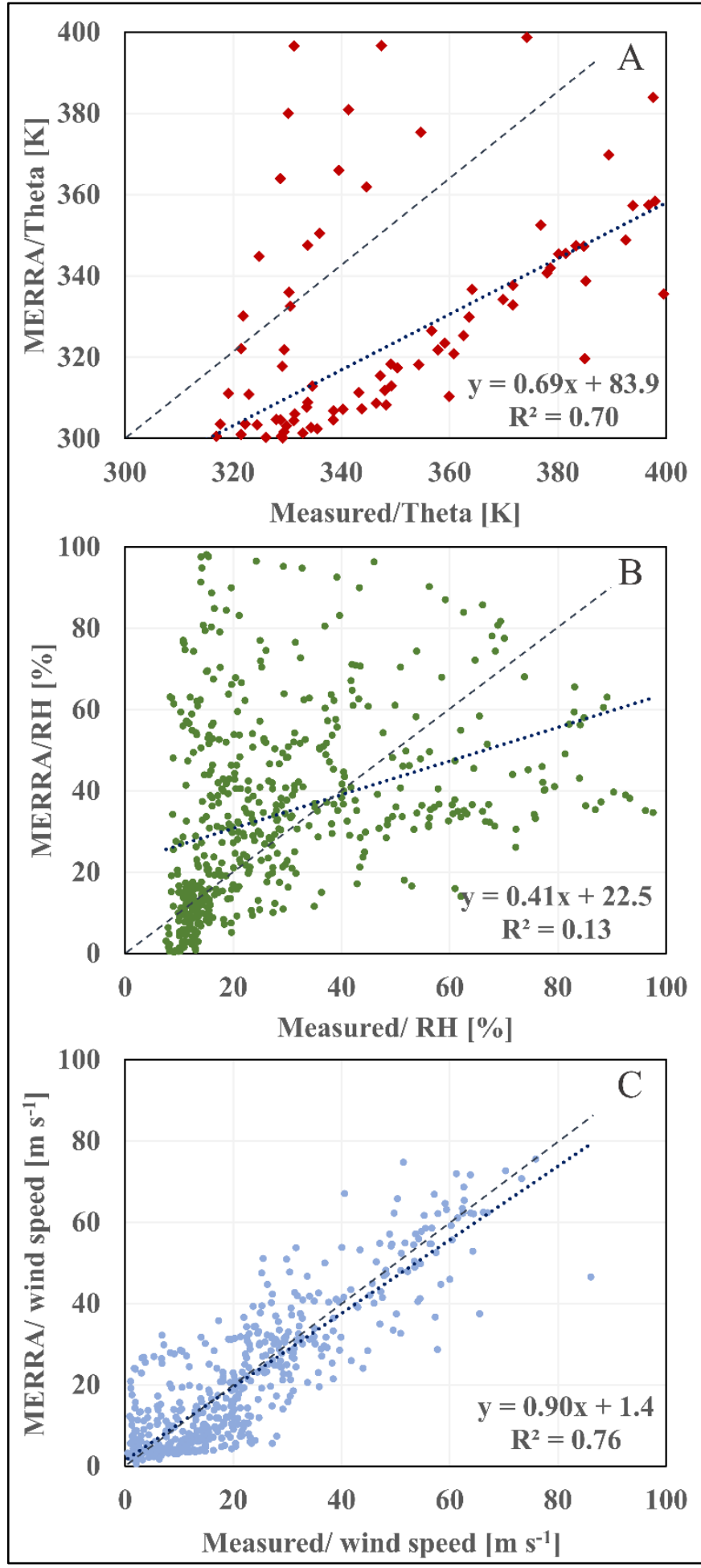

Figure 1. Scatters plots of (A) theta, (B) RH, and (C) wind speed measured in situ (X axes) versus those predicted by MERRA-2 (Y axes). Dashed lines depict standard linear regressions. 


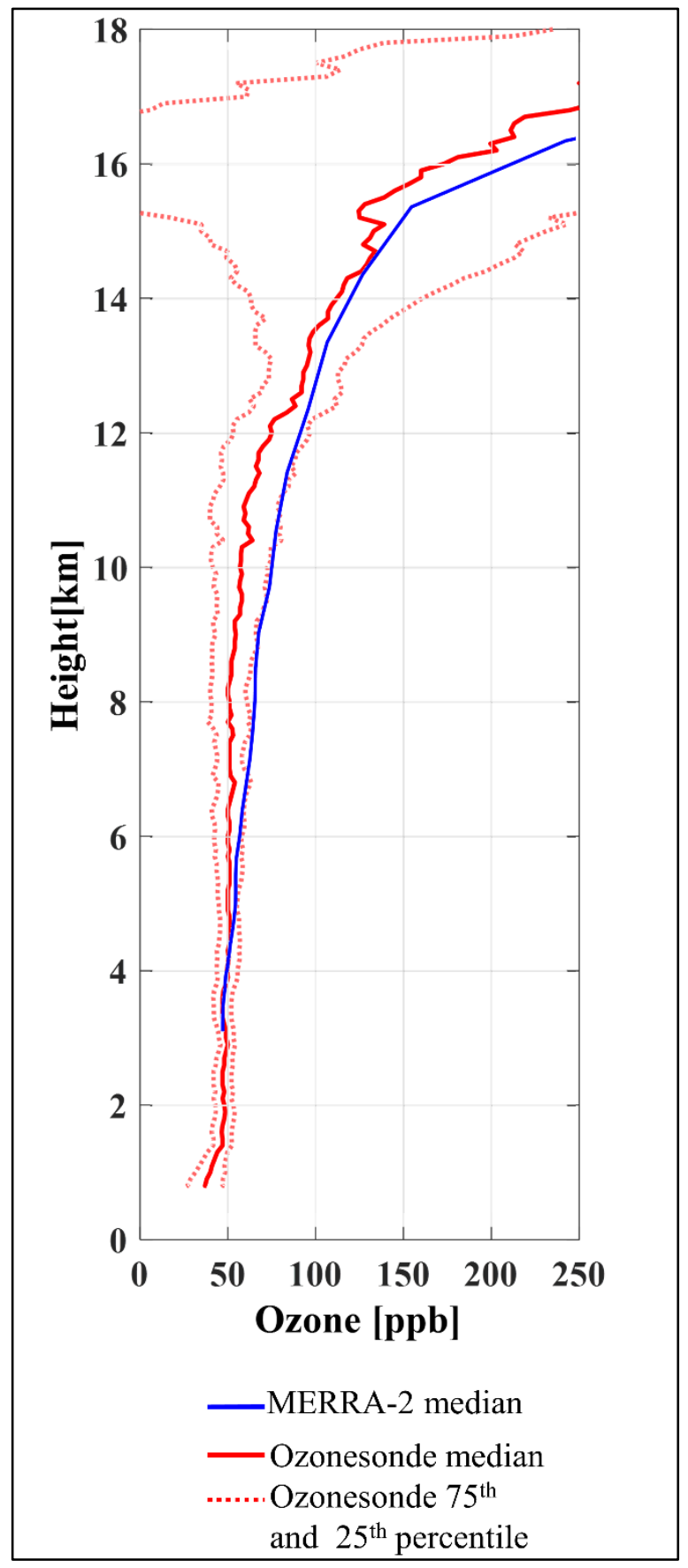

Figure 2. Vertical profiles depicted the 25 th, $50^{\text {th }}$, and 75 th percentile distributions of $\mathrm{O}_{3}$ measured with 14 sondes and the corresponding median profile predicted by MERRA-2 for the same periods. 

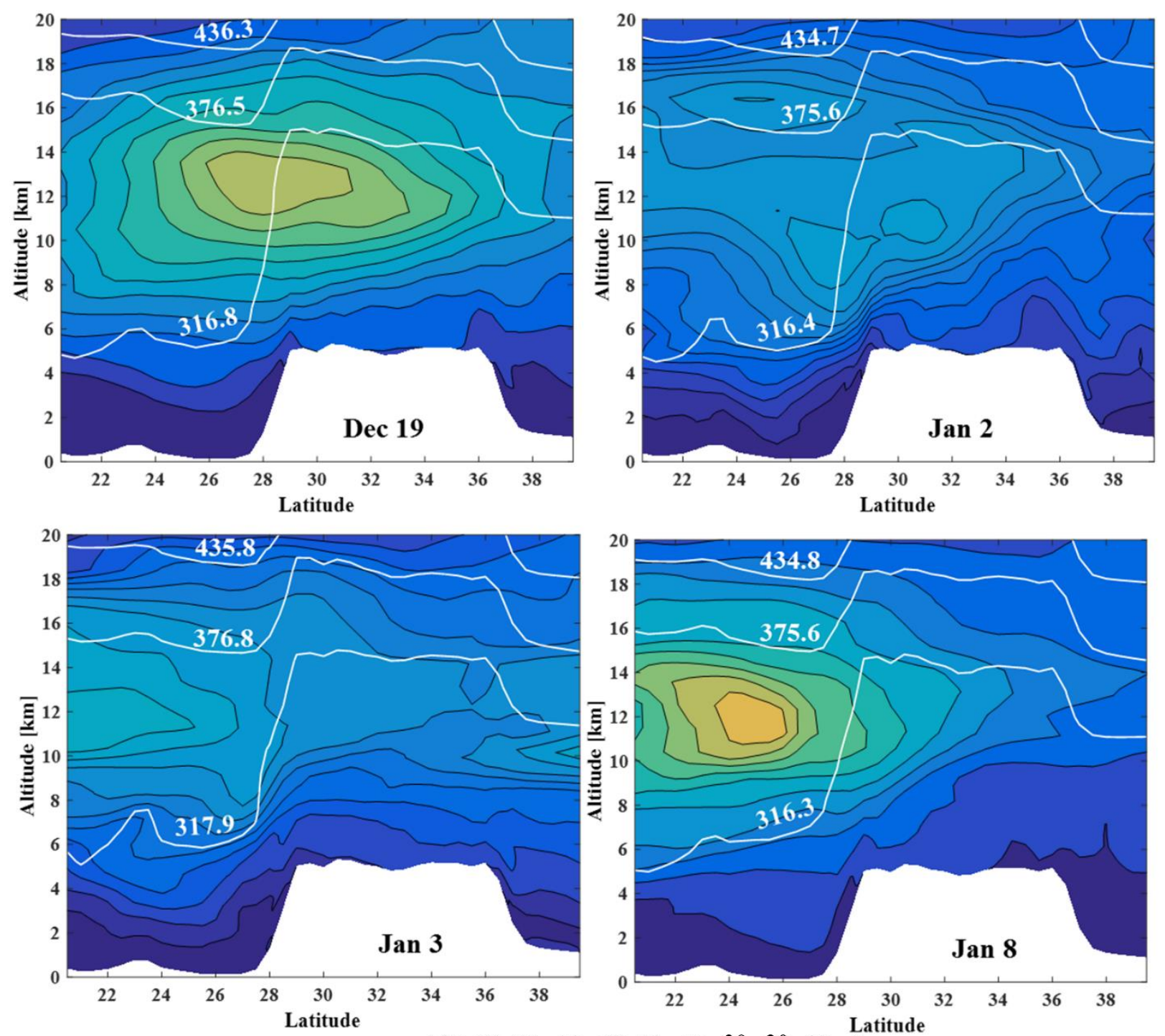

Wind speed \begin{tabular}{rrrrrrrrrrr}
100 & 90 & 80 & 70 & 60 & 50 & 40 & 30 & 20 & 10 & 0 \\
\hline & & & & & & & & & &
\end{tabular}

Figure 3. Location and structure of SJS over the Himalayan region predicted by MERRA-2 on selected days. The white lines depict isentropes. 


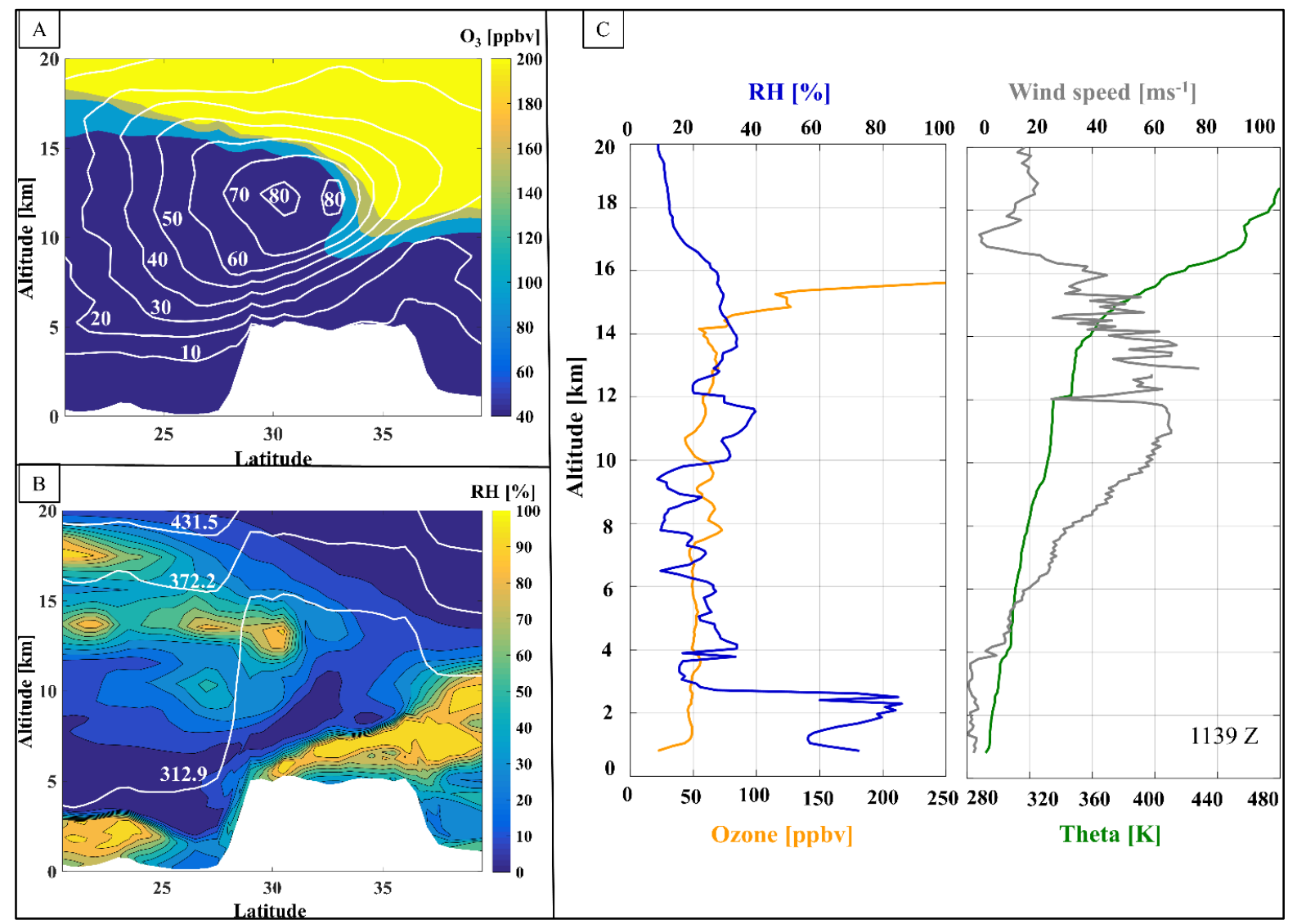

Figure 4. Curtain plots depicting (A) $\mathrm{O}_{3}$ concentration with wind speed contours and (B) $\mathrm{RH}$ with theta contours predicted by MERRA-2 at $1200 \mathrm{Z}$ on 22 December 2015 and the corresponding vertical profiles of (C) $\mathrm{O}_{3}$ and $\mathrm{RH}$ and (D) wind speed and theta measured in situ on the same day with ozonesondes (Flight 09 in Supplementary Table 1). 


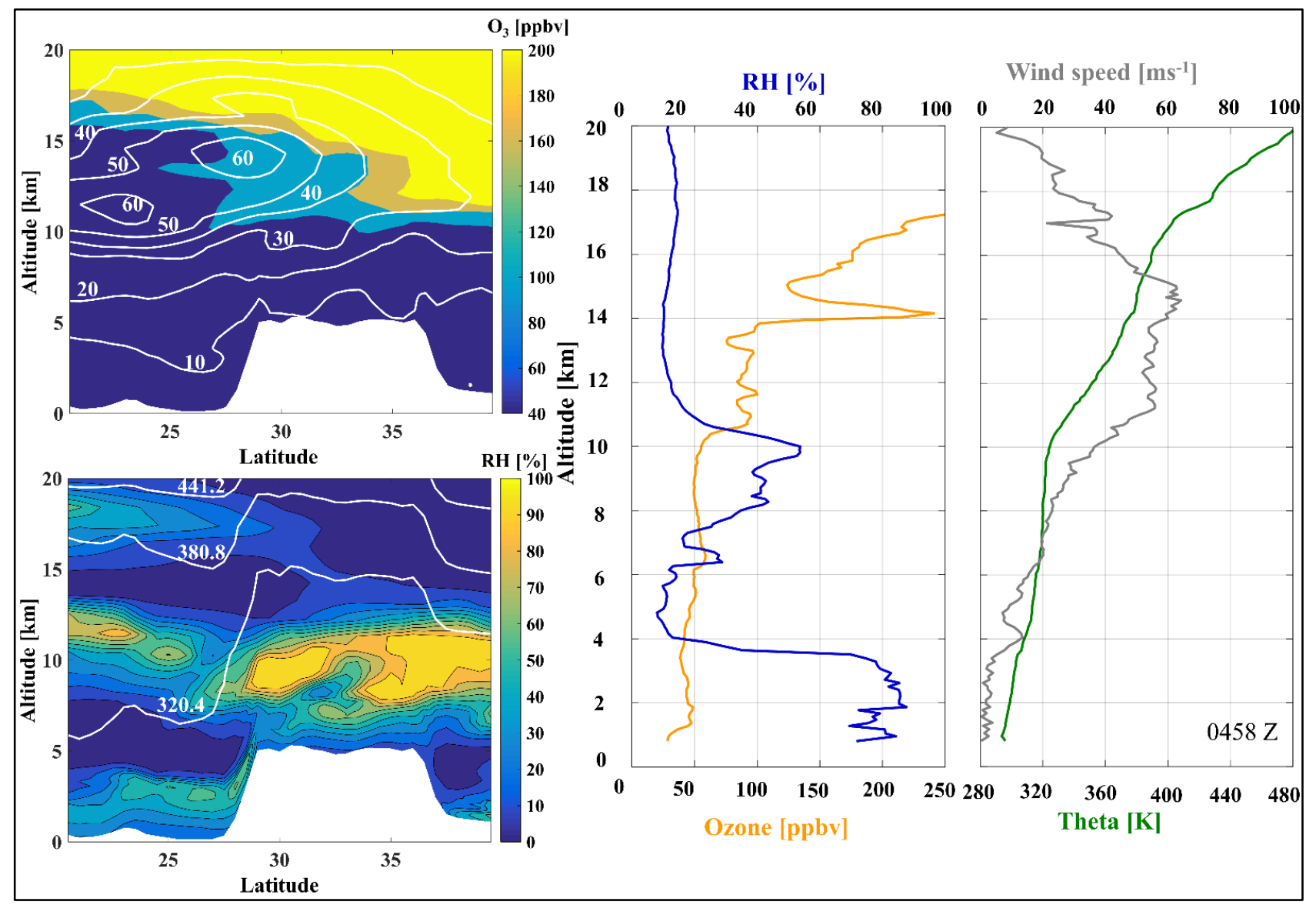

Figure 5. Curtain plots depicting (A) $\mathrm{O}_{3}$ concentration with wind speed contours and (B) $\mathrm{RH}$ with theta contours predicted by MERRA-2 at $0600 \mathrm{Z}$ on 6 January 2016 and the corresponding vertical profiles of (C) $\mathrm{O}_{3}$ and $\mathrm{RH}$ and (D) wind speed and theta measured in situ on the same day with ozonesondes (Flight 31 in Supplementary Table 1). 


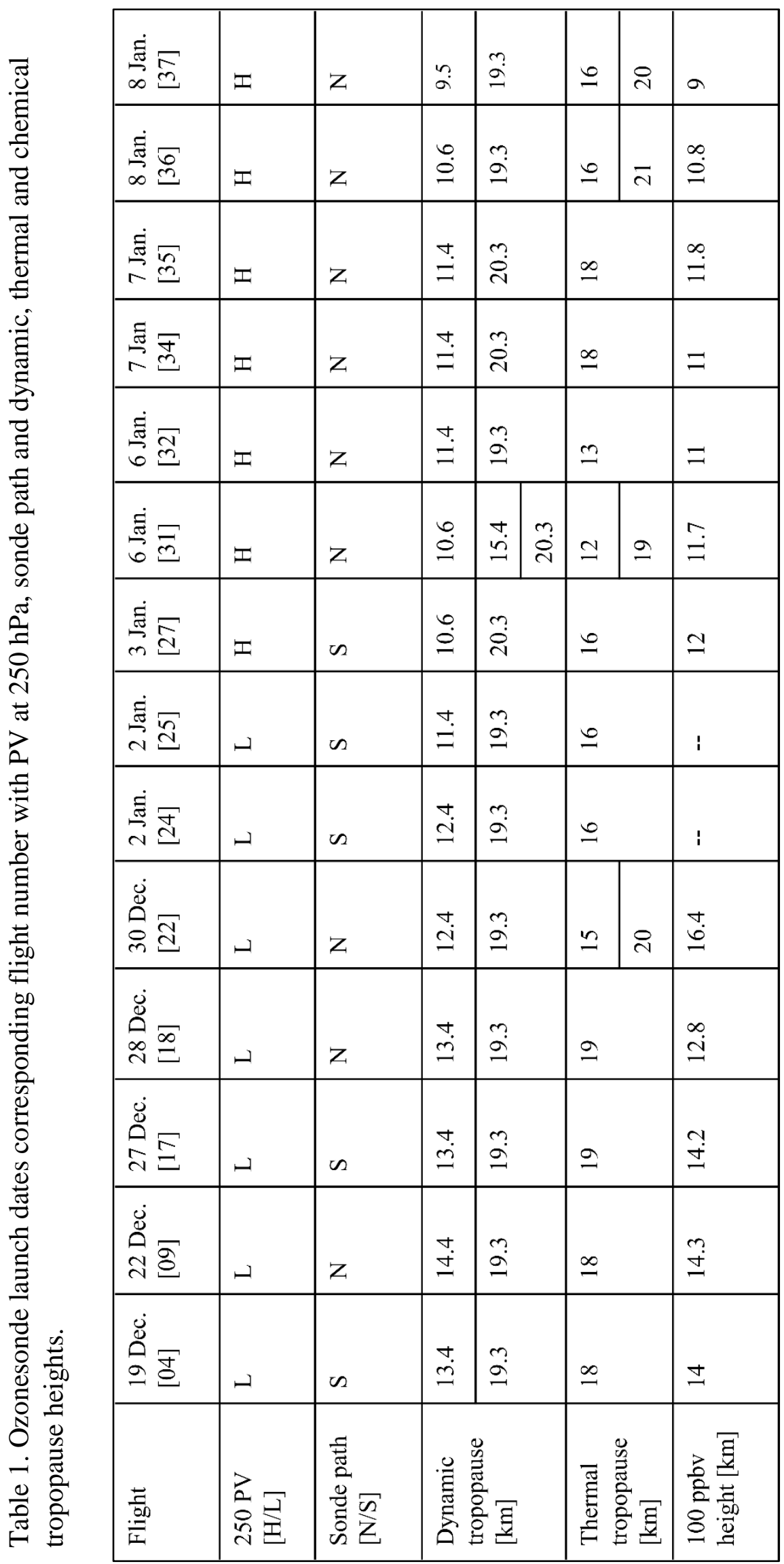




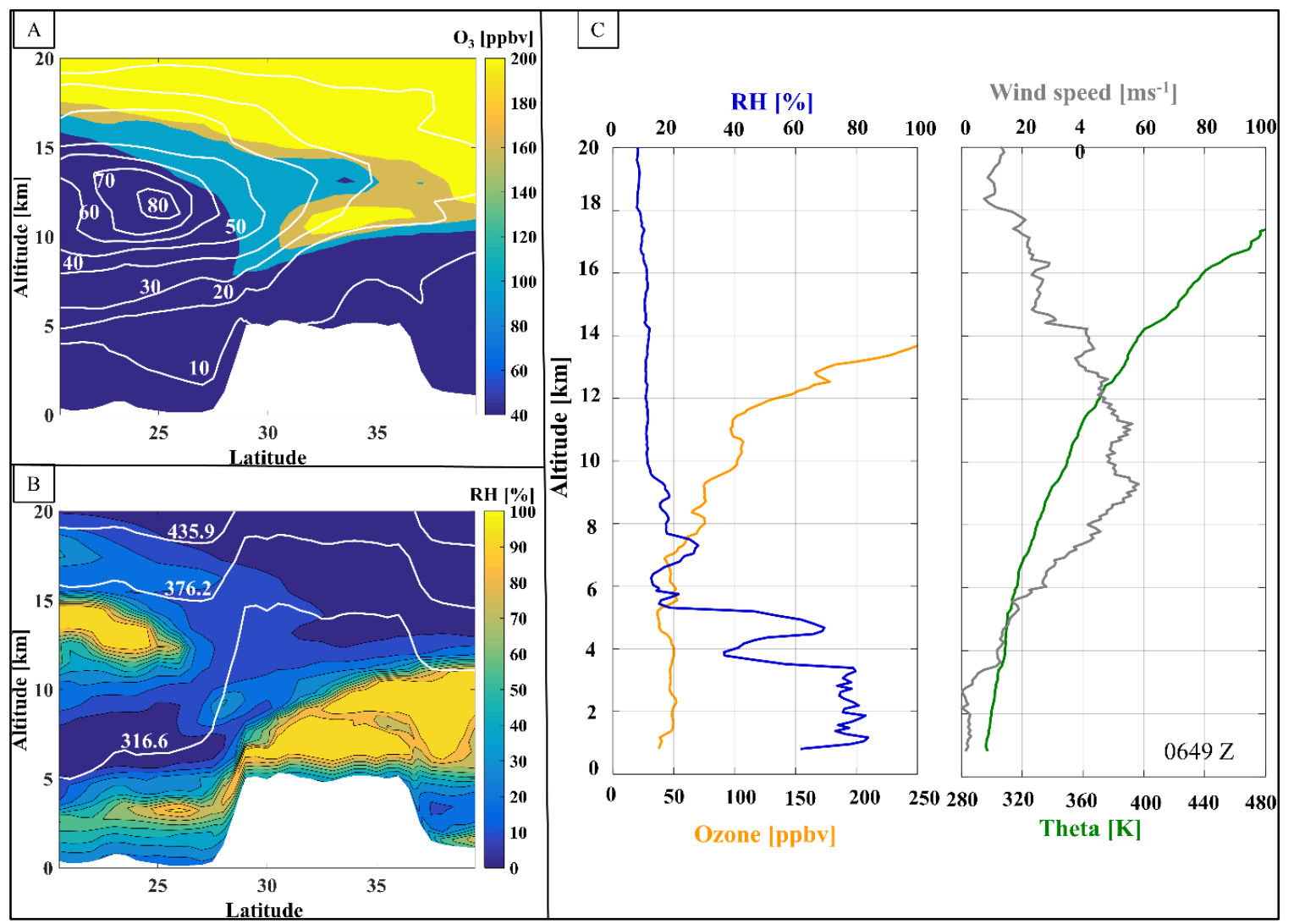

Figure 6. Curtain plots depicting (A) $\mathrm{O}_{3}$ concentration with wind speed contours and (B) $\mathrm{RH}$ with theta contours predicted by MERRA-2 at $0600 \mathrm{Z}$ on 8 January 2016 and the corresponding vertical profiles of (C) $\mathrm{O}_{3}$ and $\mathrm{RH}$ and (D) wind speed and theta measured in situ on the same day with ozonesondes (Flight 36 in Supplementary Table 1). 


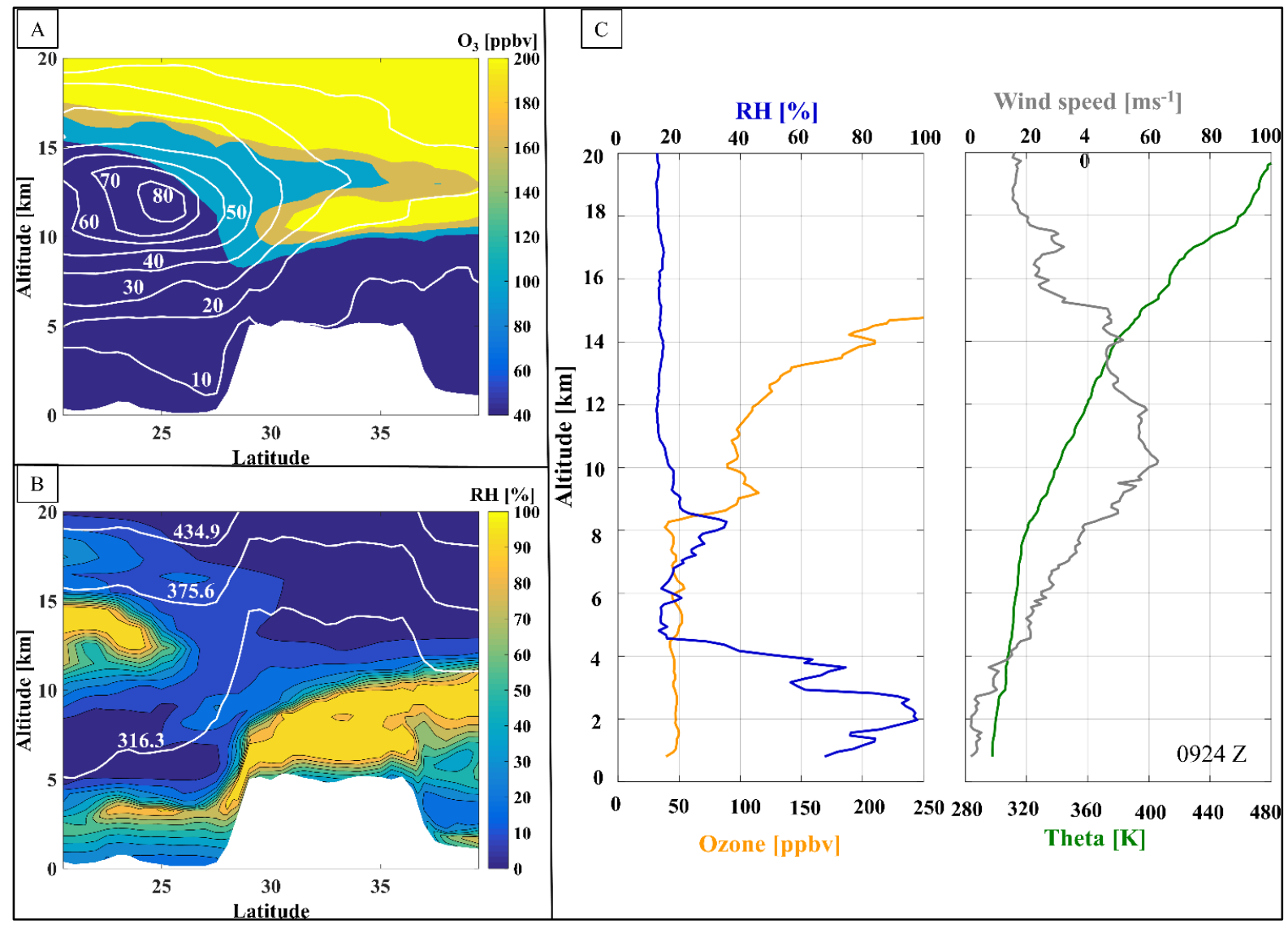

Figure 7. Curtain plots depicting (A) $\mathrm{O}_{3}$ concentration with wind speed contours and (B) $\mathrm{RH}$ with theta contours predicted by MERRA-2 at $0900 \mathrm{Z}$ on 8 January 2016 and the corresponding vertical profiles of $(\mathrm{C}) \mathrm{O}_{3}$ and $\mathrm{RH}$ and (D) wind speed and theta measured in situ on the same day with ozonesondes (Flight 37 in Supplementary Table 1). 


\section{$\underline{\text { Supplementary material }}$}

Supplementary Table 1. Ozonesonde launch dates and times (local time is GMT +5 hours 45 minutes).

\begin{tabular}{|l|l|l|}
\hline Date & Flight no. & Time (GMT) \\
\hline 19 Dec. & 004 & 0639 \\
\hline 22 Dec. & 009 & 1139 \\
\hline 27 Dec. & 017 & 0806 \\
\hline 28 Dec. & 018 & 0635 \\
\hline 30 Dec. & 022 & 0431 \\
\hline 2 Jan. & 024 & 0731 \\
\hline 2 Jan. & 025 & 1045 \\
\hline 3 Jan. & 027 & 1027 \\
\hline 6 Jan. & 031 & 0458 \\
\hline 6 Jan. & 032 & 0820 \\
\hline 7 Jan. & 034 & 0624 \\
\hline 7 Jan. & 035 & 1031 \\
\hline 8 Jan. & 036 & 0649 \\
\hline 8 Jan. & 037 & 0924 \\
\hline
\end{tabular}




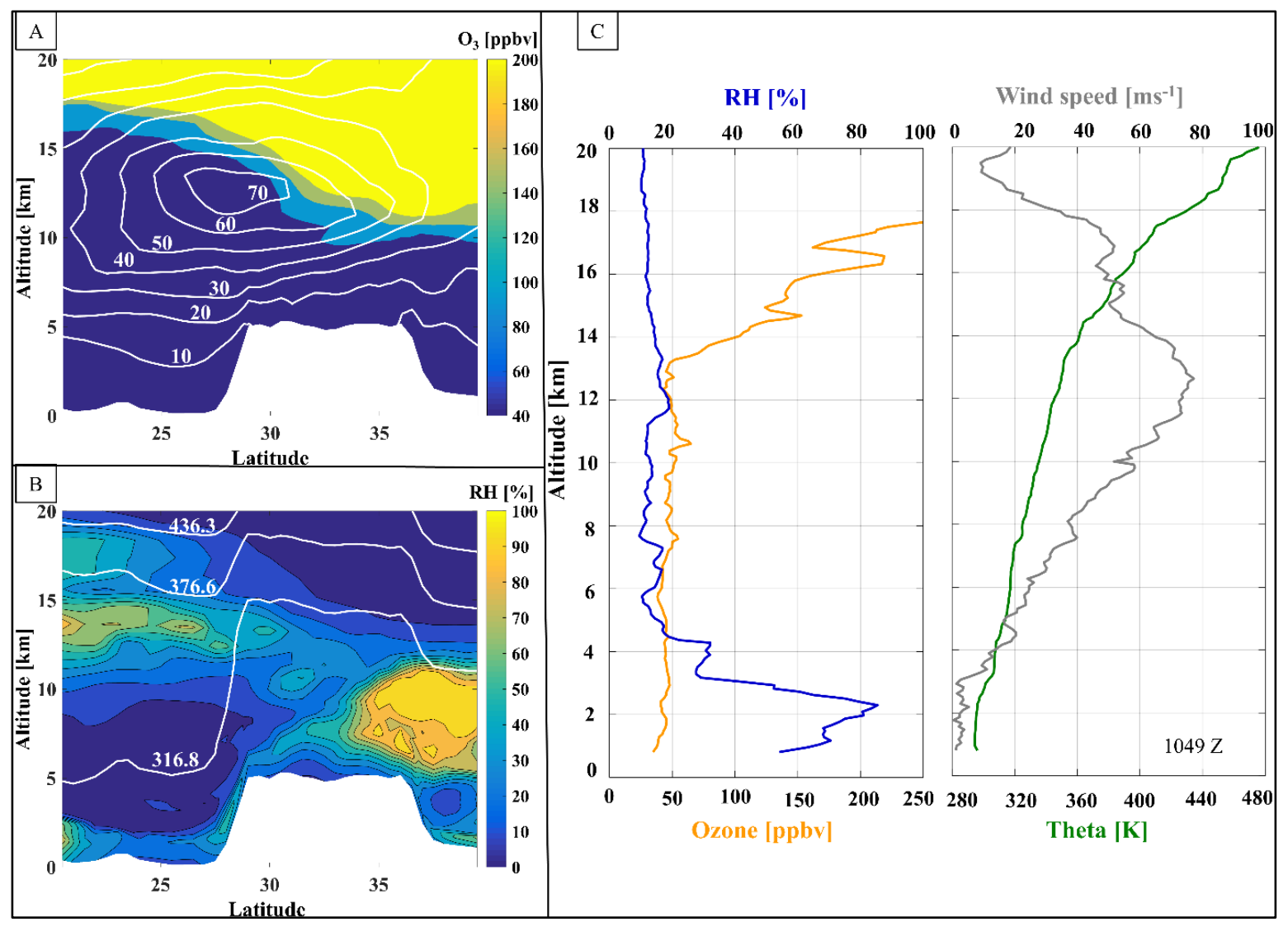

Supplementary Figure 1. Curtain plots depicting (A) $\mathrm{O}_{3}$ concentration with wind speed contours and (B) RH with theta contours predicted by MERRA-2 at $1200 \mathrm{Z}$ on 19 December 2016 and the corresponding vertical profiles of (C) $\mathrm{O}_{3}$ and $\mathrm{RH}$ and (D) wind speed and theta measured in situ on the same day with ozonesondes (Flight 04 in Supplementary Table 1). 


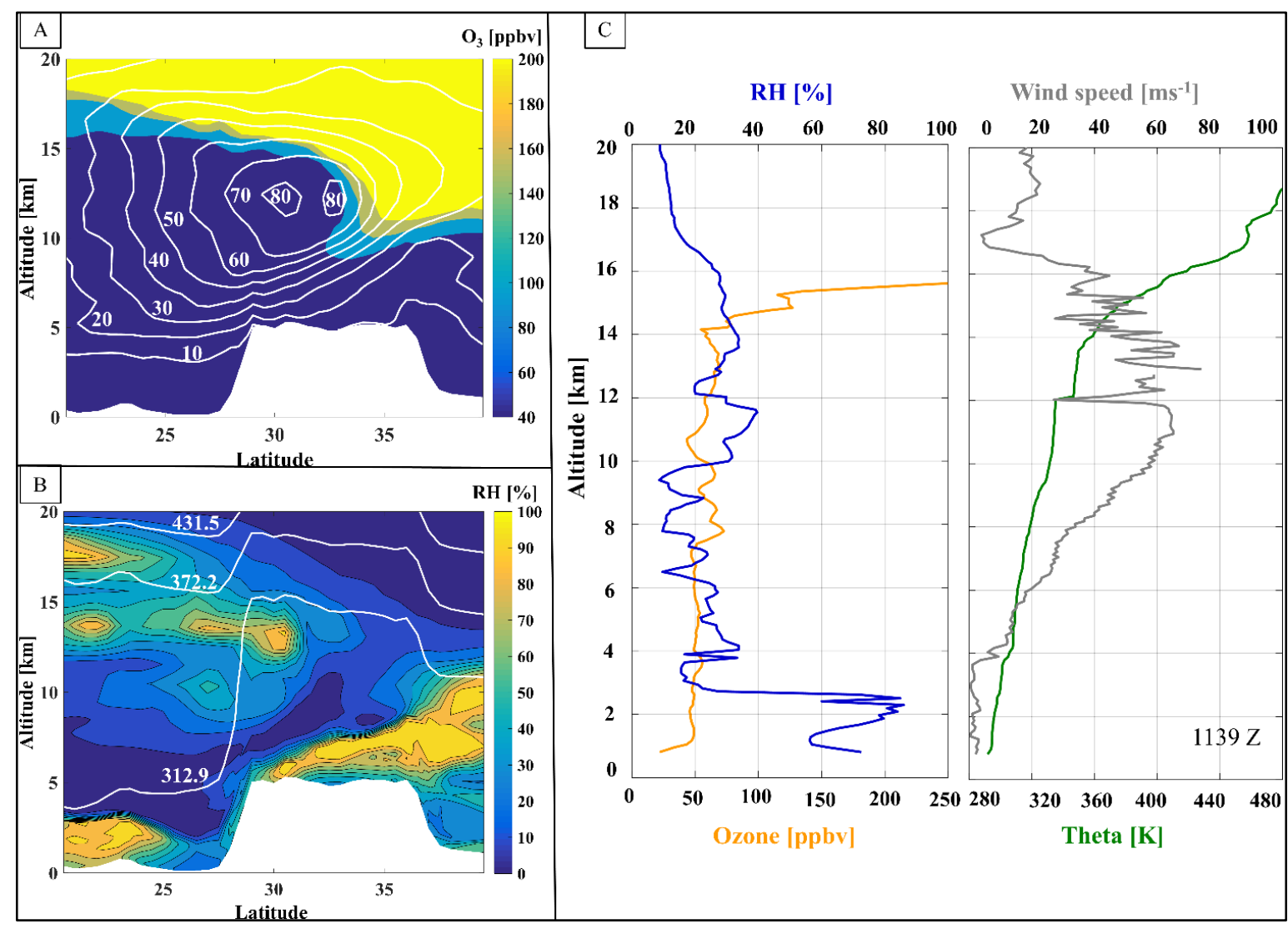

Supplementary Figure 2. Curtain plots depicting (A) $\mathrm{O}_{3}$ concentration with wind speed contours and (B) RH with theta contours predicted by MERRA-2 at $1200 \mathrm{Z}$ on 22 December 2015 and the corresponding vertical profiles of (C) $\mathrm{O}_{3}$ and $\mathrm{RH}$ and (D) wind speed and theta measured in situ on the same day with ozonesondes (Flight 09 in Supplementary Table 1). 


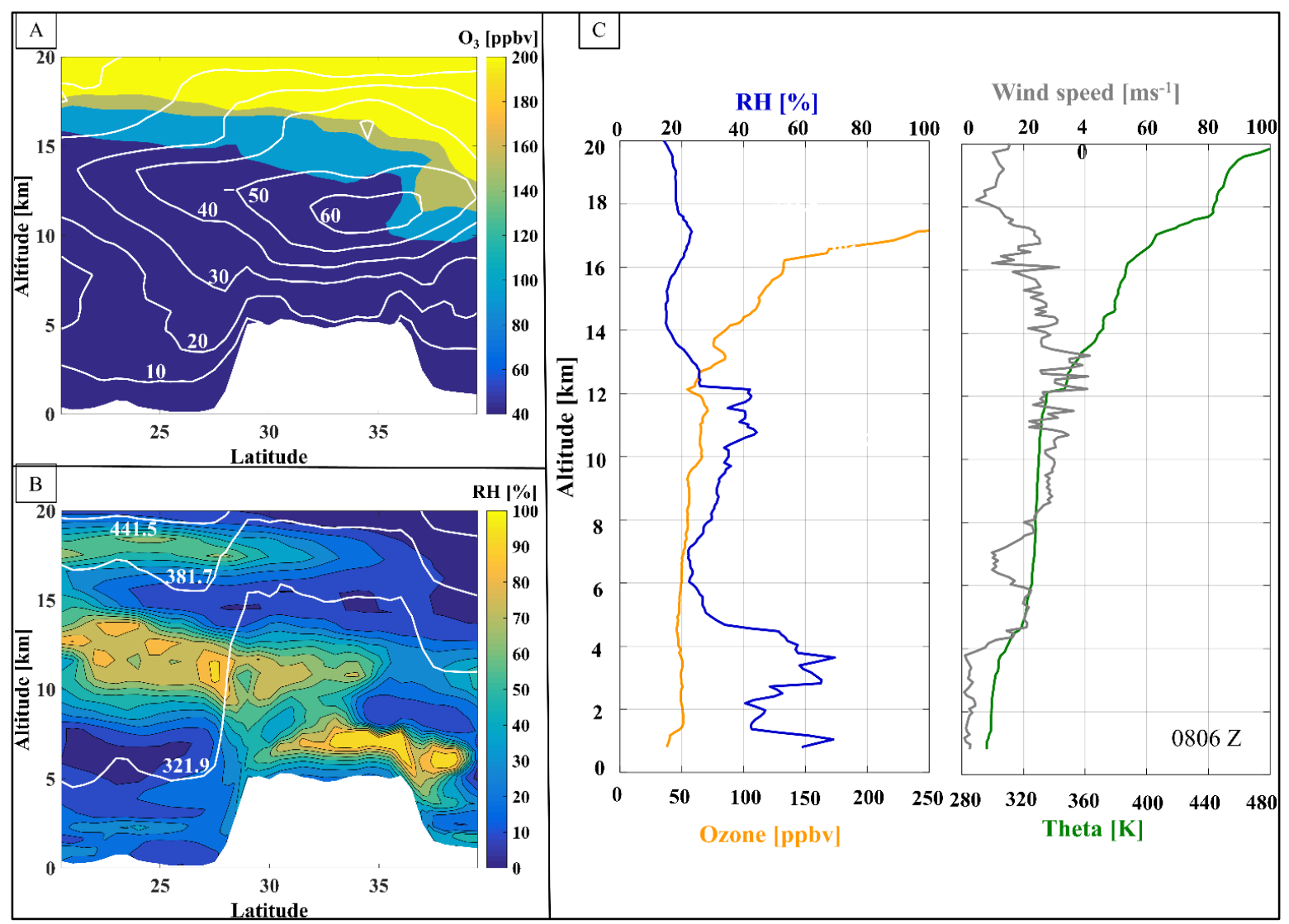

Supplementary Figure 3. Curtain plots depicting (A) $\mathrm{O}_{3}$ concentration with wind speed contours and (B) RH with theta contours predicted by MERRA-2 at $0900 \mathrm{Z}$ on 26 December 2015 and the corresponding vertical profiles of (C) $\mathrm{O}_{3}$ and $\mathrm{RH}$ and (D) wind speed and theta measured in situ on the same day with ozonesondes (Flight 17 in Supplementary Table 1). 


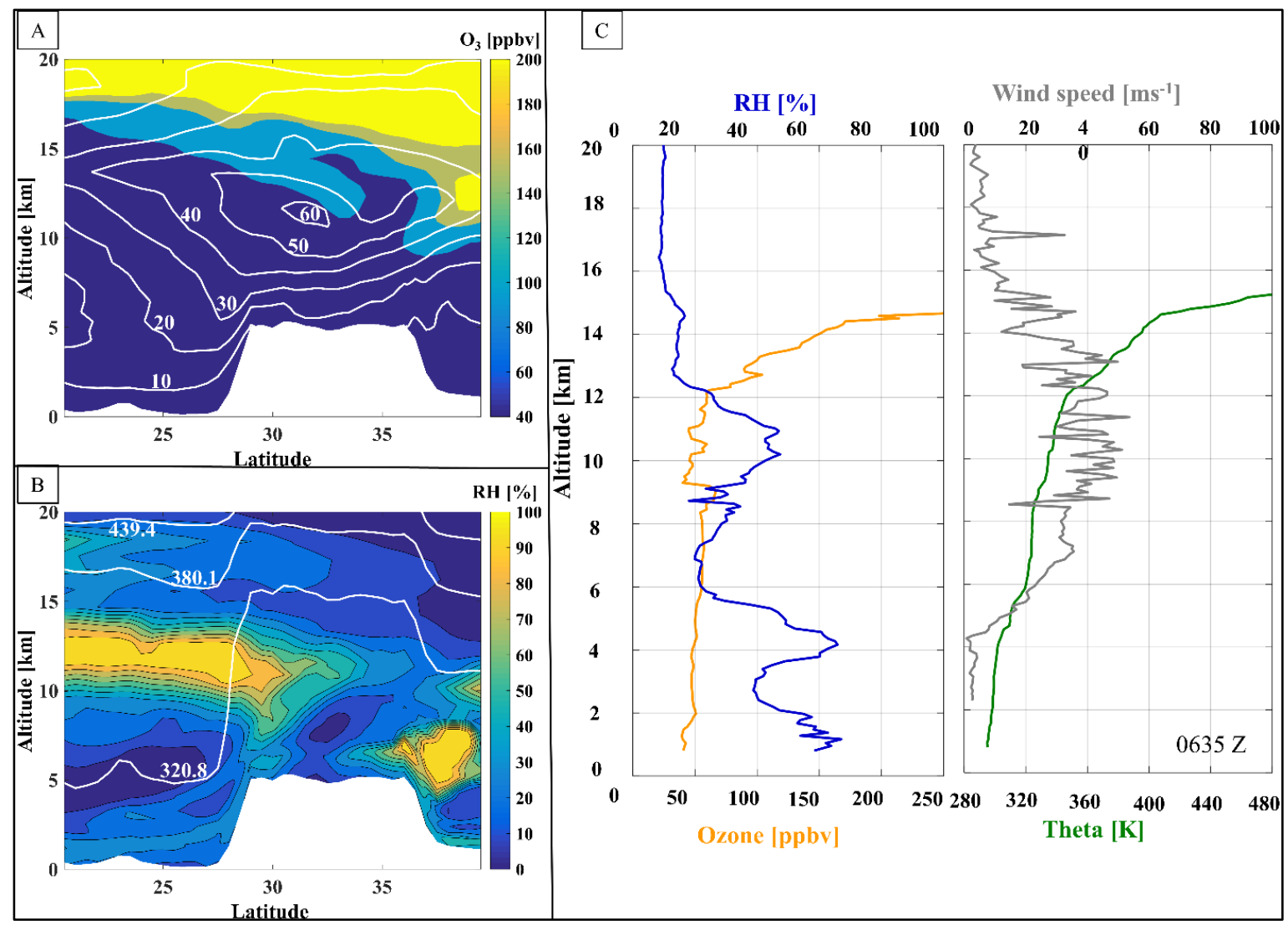

Supplementary Figure 4. Curtain plots depicting (A) $\mathrm{O}_{3}$ concentration with wind speed contours and (B) RH with theta contours predicted by MERRA-2 at $0600 \mathrm{Z}$ on 28 December 2015 and the corresponding vertical profiles of (C) $\mathrm{O}_{3}$ and $\mathrm{RH}$ and (D) wind speed and theta measured in situ on the same day with ozonesondes (Flight 18 in Supplementary Table 1). 


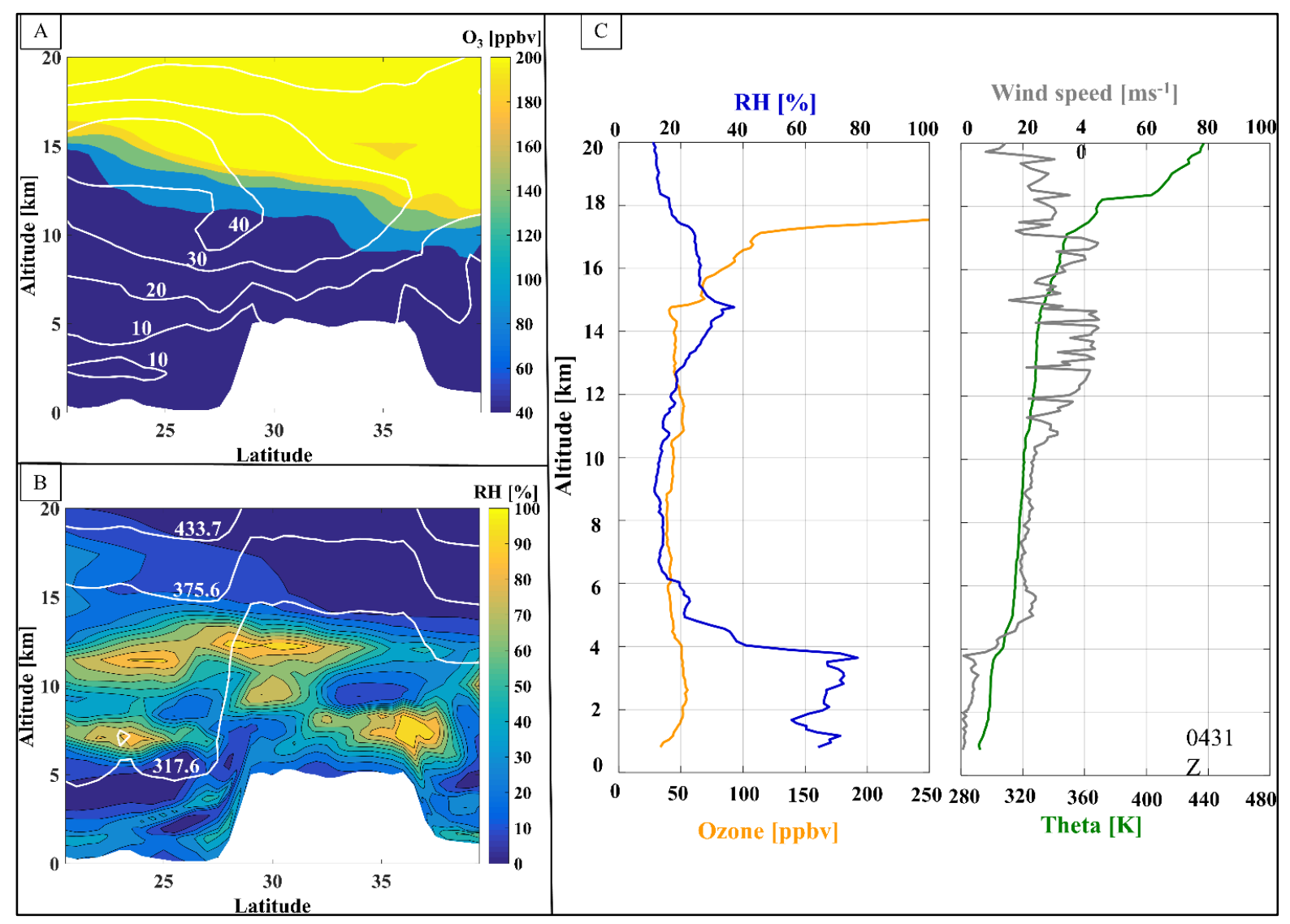

Supplementary Figure 5. Curtain plots depicting (A) $\mathrm{O}_{3}$ concentration with wind speed contours and (B) RH with theta contours predicted by MERRA-2 at $0600 \mathrm{Z}$ on 30 December 2015 and the corresponding vertical profiles of (C) $\mathrm{O}_{3}$ and $\mathrm{RH}$ and (D) wind speed and theta measured in situ on the same day with ozonesondes (Flight 22 in Supplementary Table 1). 


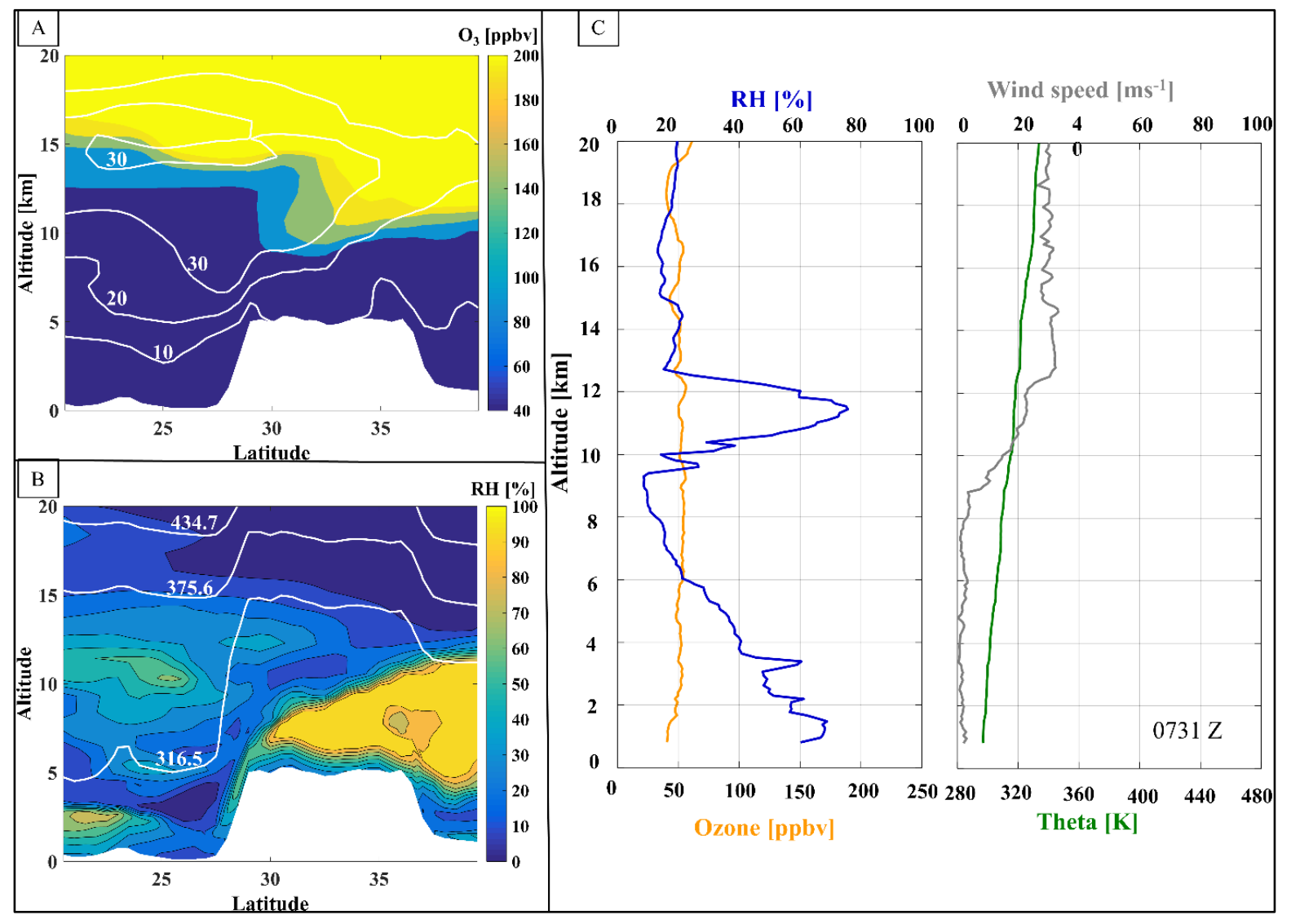

Supplementary Figure 6. Curtain plots depicting (A) $\mathrm{O}_{3}$ concentration with wind speed contours and (B) RH with theta contours predicted by MERRA-2 at $0900 \mathrm{Z}$ on 2 January 2016 and the corresponding vertical profiles of (C) $\mathrm{O}_{3}$ and $\mathrm{RH}$ and (D) wind speed and theta measured in situ on the same day with ozonesondes (Flight 24 in Supplementary Table 1). 


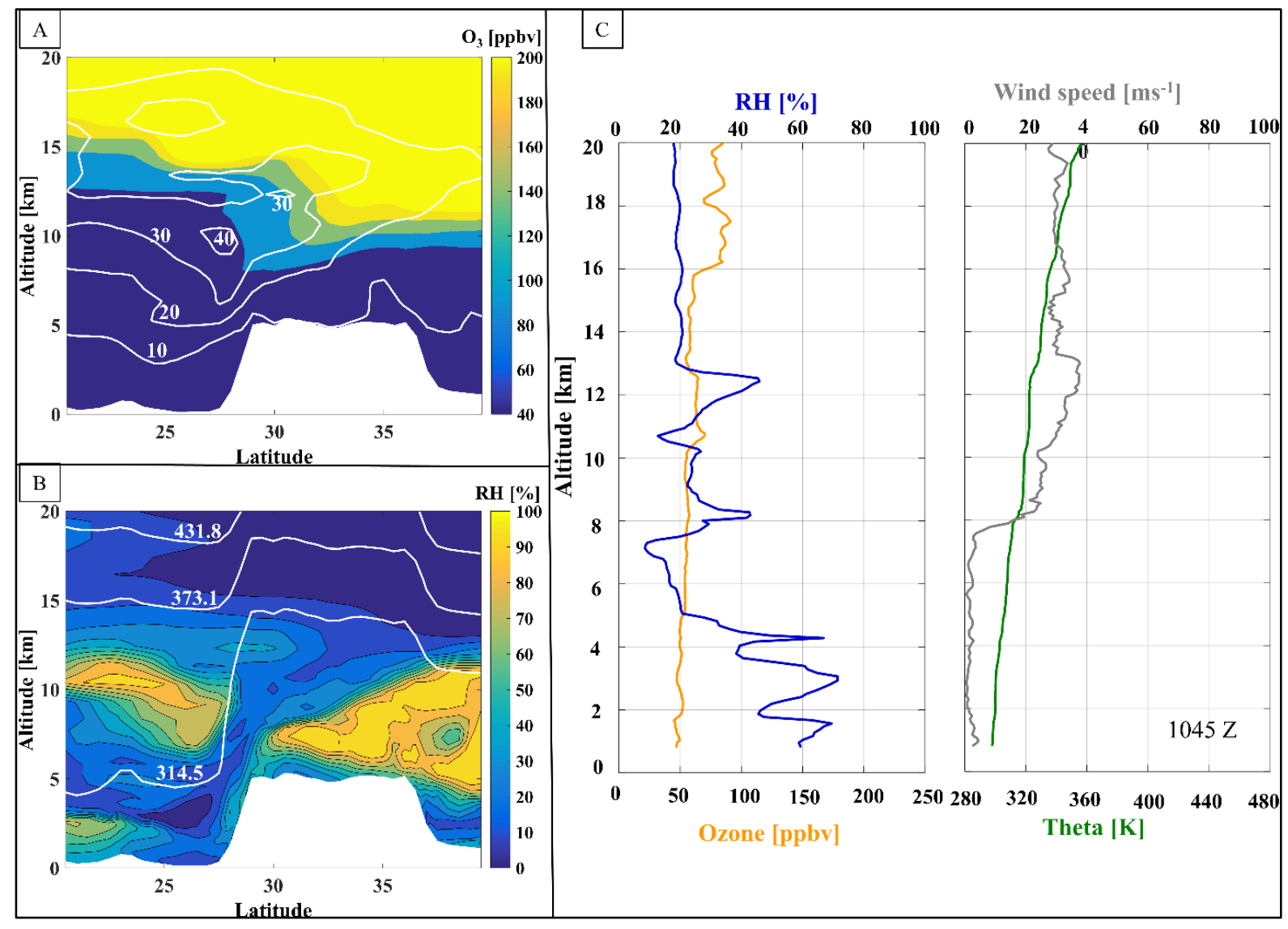

Supplementary Figure 7. Curtain plots depicting (A) $\mathrm{O}_{3}$ concentration with wind speed contours and (B) RH with theta contours predicted by MERRA-2 at $0900 \mathrm{Z}$ on 2 January 2016 and the corresponding vertical profiles of (C) $\mathrm{O}_{3}$ and $\mathrm{RH}$ and (D) wind speed and theta measured in situ on the same day with ozonesondes (Flight 25 in Supplementary Table 1). 


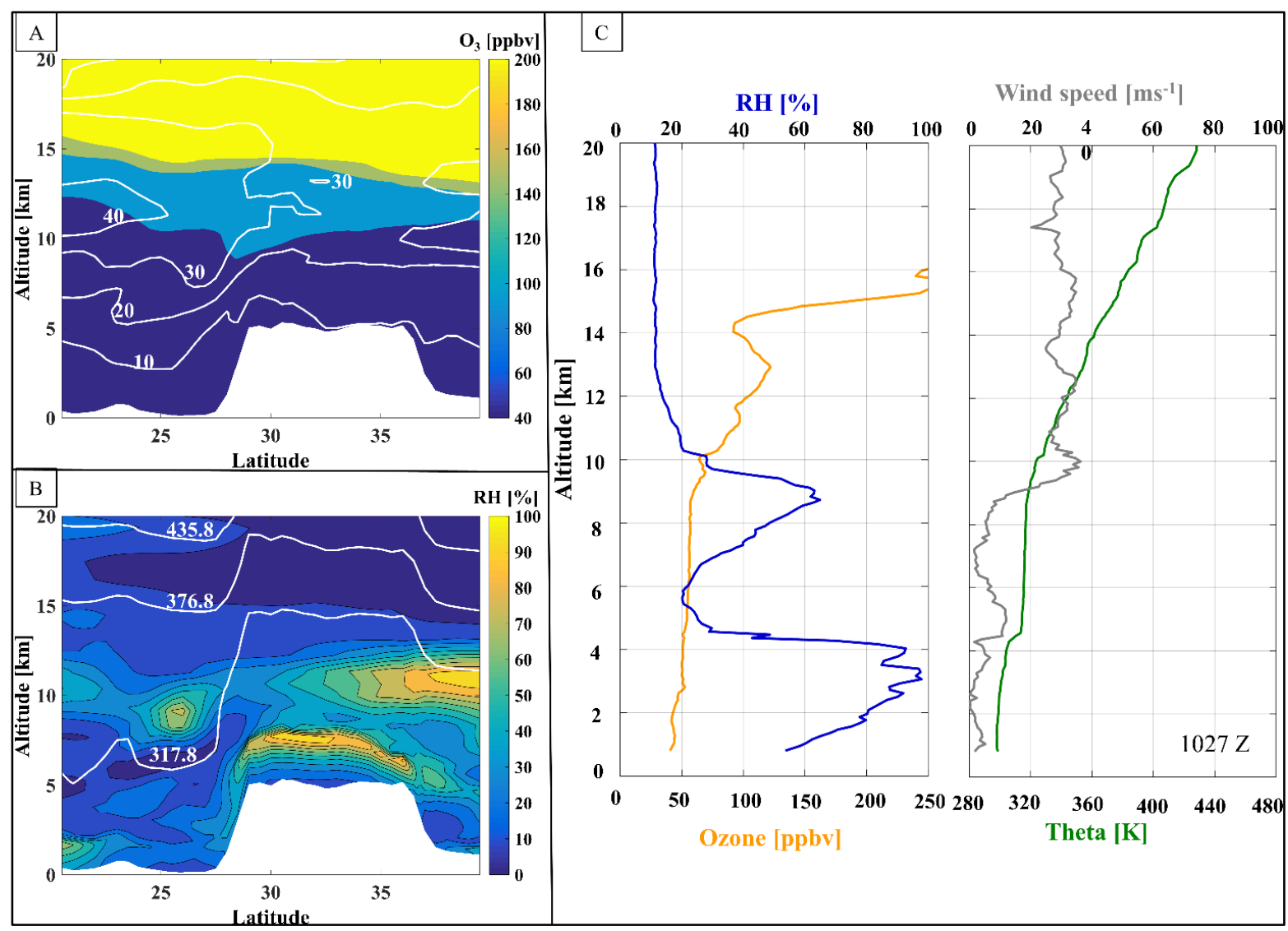

Supplementary Figure 8. Curtain plots depicting (A) $\mathrm{O}_{3}$ concentration with wind speed contours and (B) RH with theta contours predicted by MERRA-2 at $0900 \mathrm{Z}$ on 3 January 2016 and the corresponding vertical profiles of (C) $\mathrm{O}_{3}$ and $\mathrm{RH}$ and (D) wind speed and theta measured in situ on the same day with ozonesondes (Flight 27 in Supplementary Table 1). 


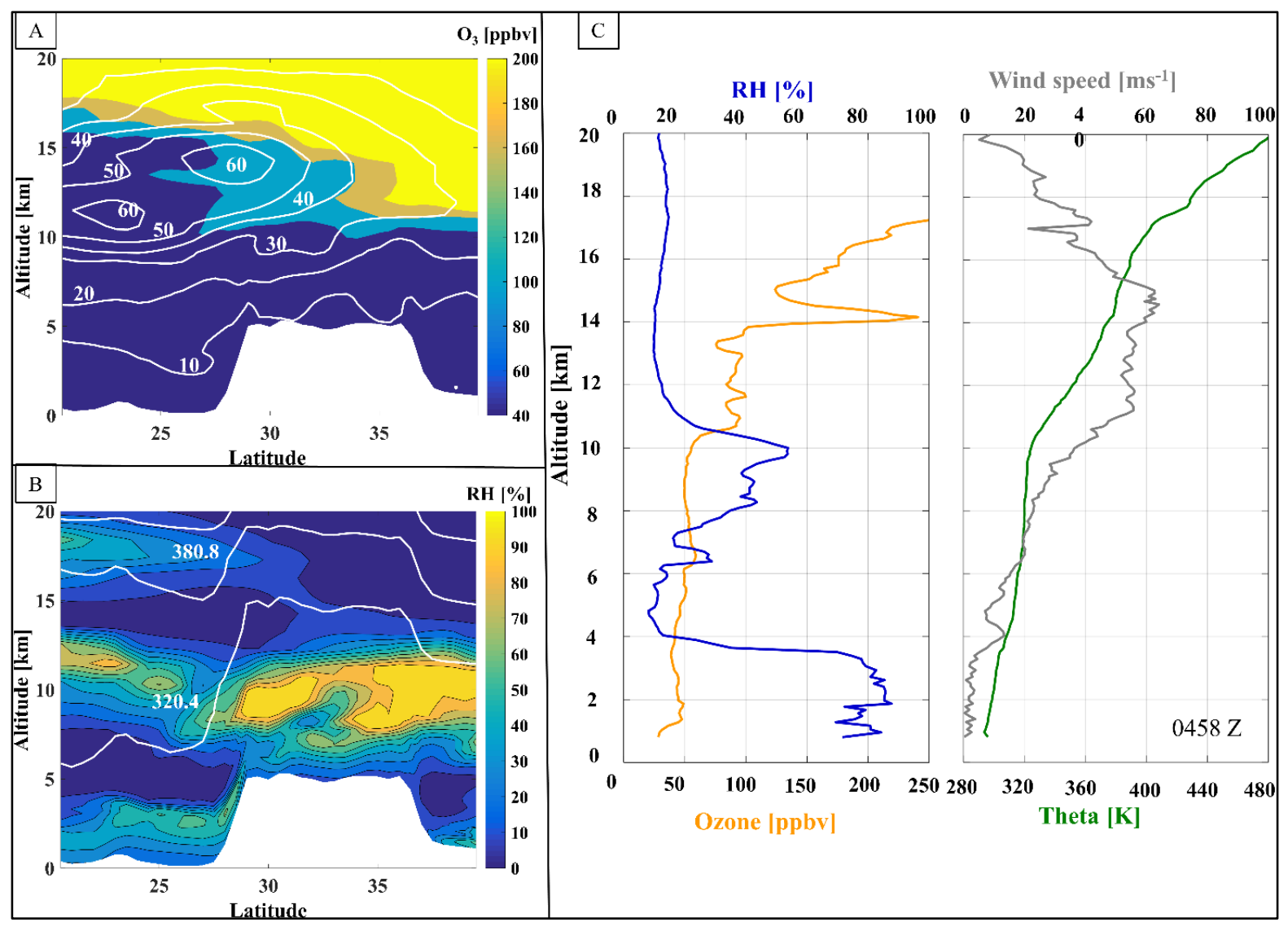

Supplementary Figure 9. Curtain plots depicting (A) $\mathrm{O}_{3}$ concentration with wind speed contours and (B) RH with theta contours predicted by MERRA-2 at $0900 \mathrm{Z}$ on 6 January 2016 and the corresponding vertical profiles of (C) $\mathrm{O}_{3}$ and $\mathrm{RH}$ and (D) wind speed and theta measured in situ on the same day with ozonesondes (Flight 31 in Supplementary Table 1). 


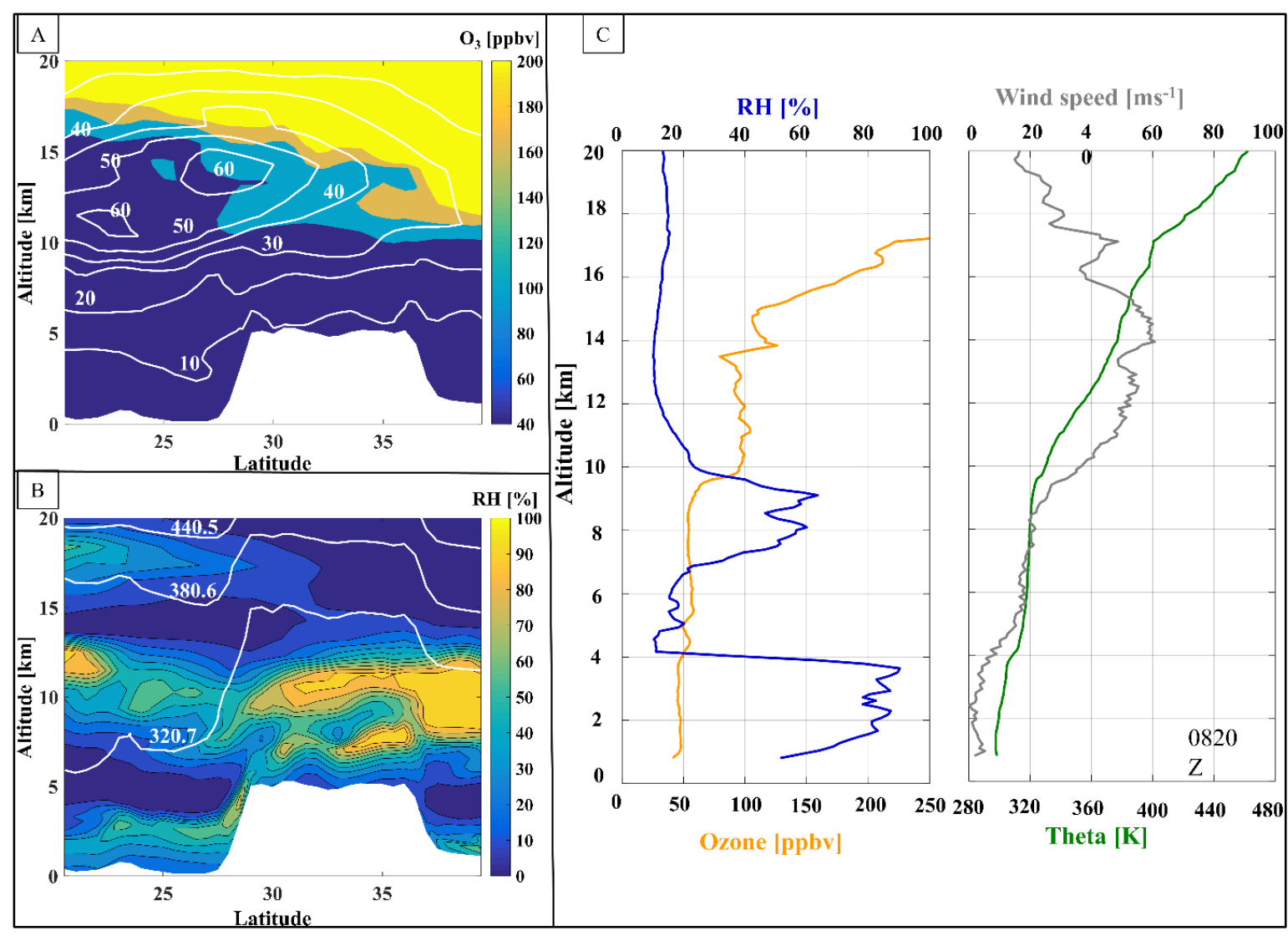

Supplementary Figure 10. Curtain plots depicting (A) $\mathrm{O}_{3}$ concentration with wind speed contours and (B) RH with theta contours predicted by MERRA-2 at $0900 \mathrm{Z}$ on 6 January 2016 and the corresponding vertical profiles of (C) $\mathrm{O}_{3}$ and $\mathrm{RH}$ and (D) wind speed and theta measured in situ on the same day with ozonesondes (Flight 32 in Supplementary Table 1). 


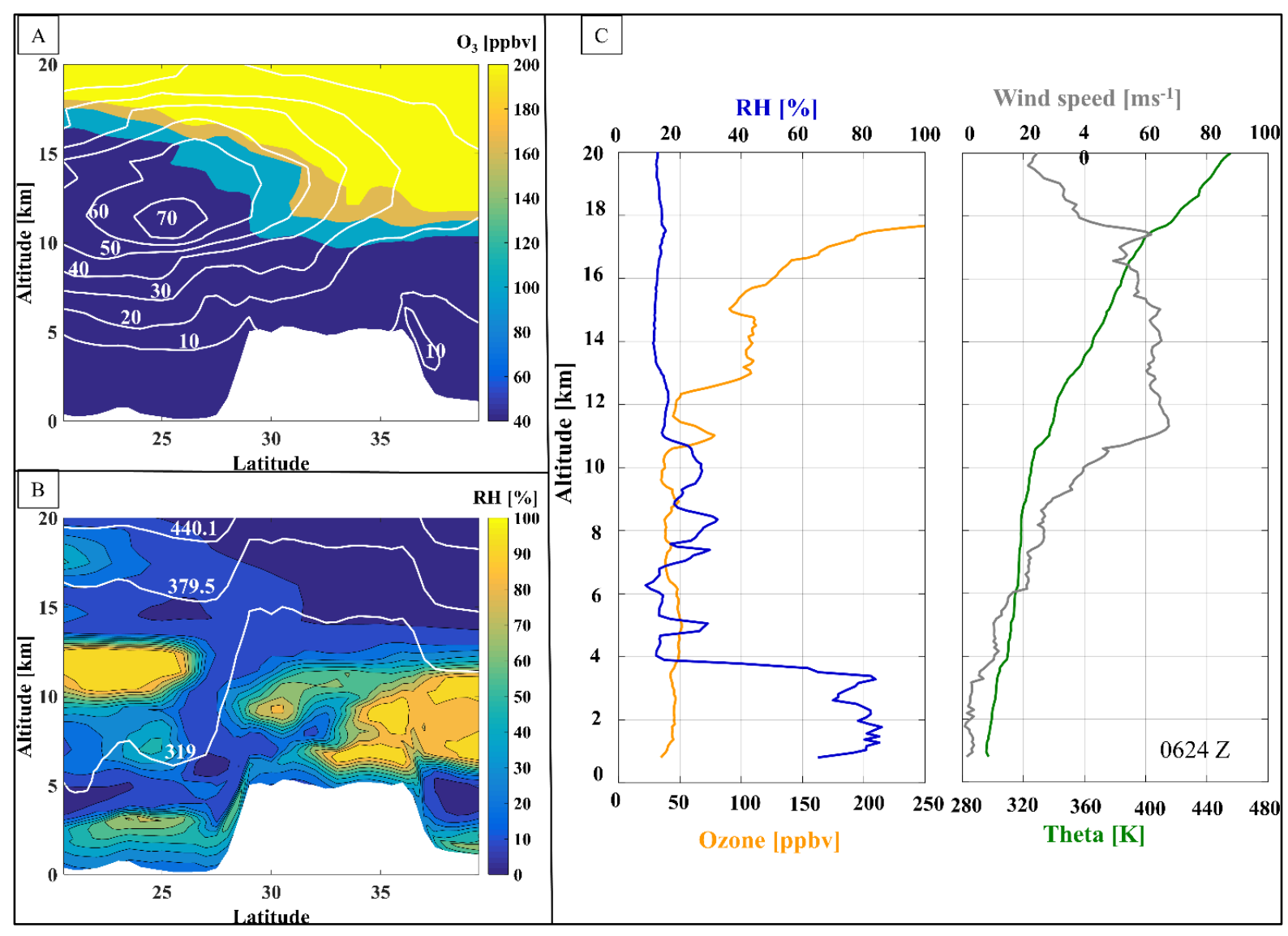

Supplementary Figure 11. Curtain plots depicting (A) $\mathrm{O}_{3}$ concentration with wind speed contours and (B) RH with theta contours predicted by MERRA-2 at $0600 \mathrm{Z}$ on 7 January 2016 and the corresponding vertical profiles of (C) $\mathrm{O}_{3}$ and $\mathrm{RH}$ and (D) wind speed and theta measured in situ on the same day with ozonesondes (Flight 34 in Supplementary Table 1). 


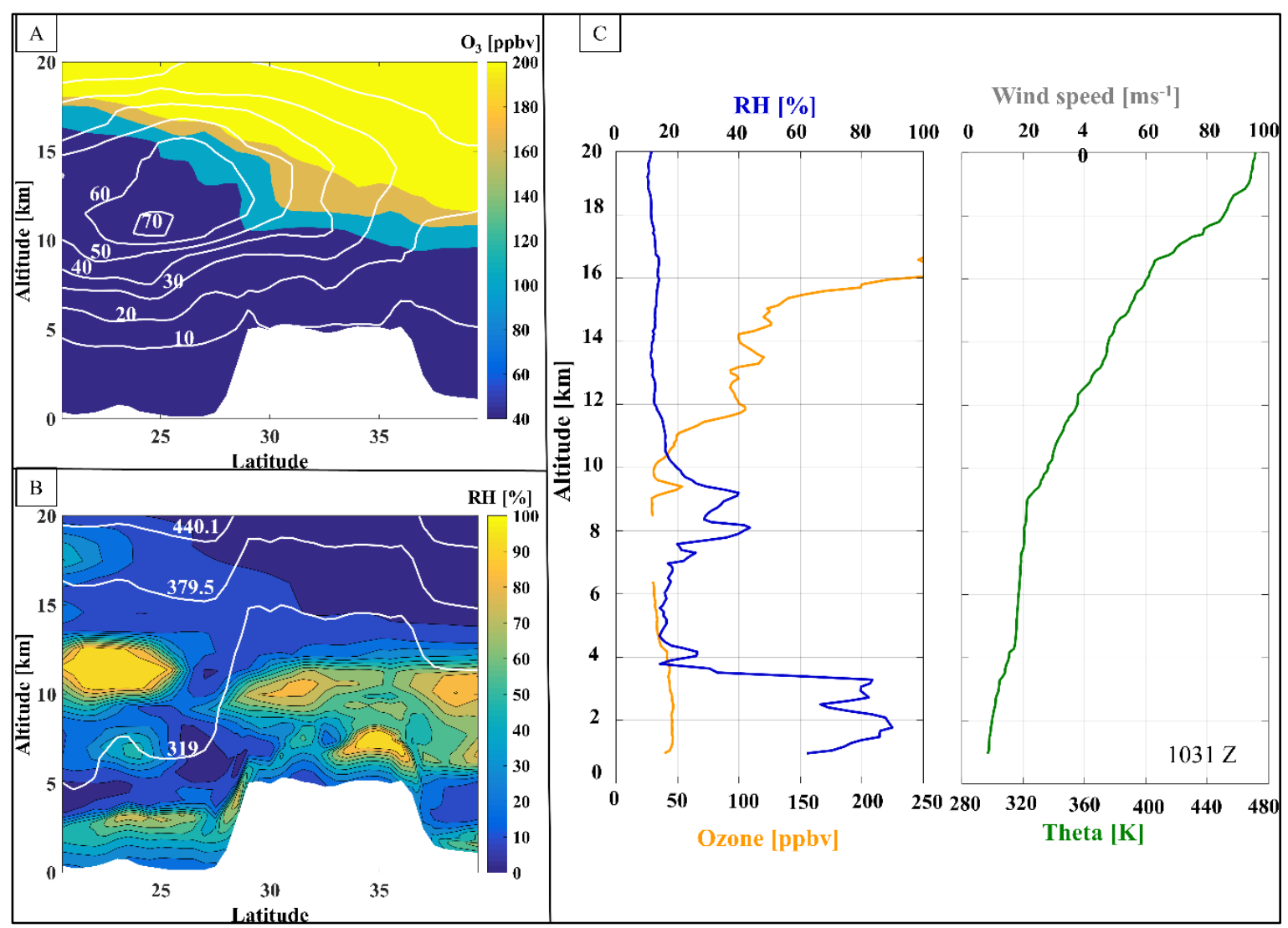

Supplementary Figure 12. Curtain plots depicting (A) $\mathrm{O}_{3}$ concentration with wind speed contours and (B) RH with theta contours predicted by MERRA-2 at $0900 \mathrm{Z}$ on 7 January 2016 and the corresponding vertical profiles of $(\mathrm{C}) \mathrm{O}_{3}$ and $\mathrm{RH}$ and (D) wind speed and theta measured in situ on the same day with ozonesondes (Flight 35 in Supplementary Table 1). 


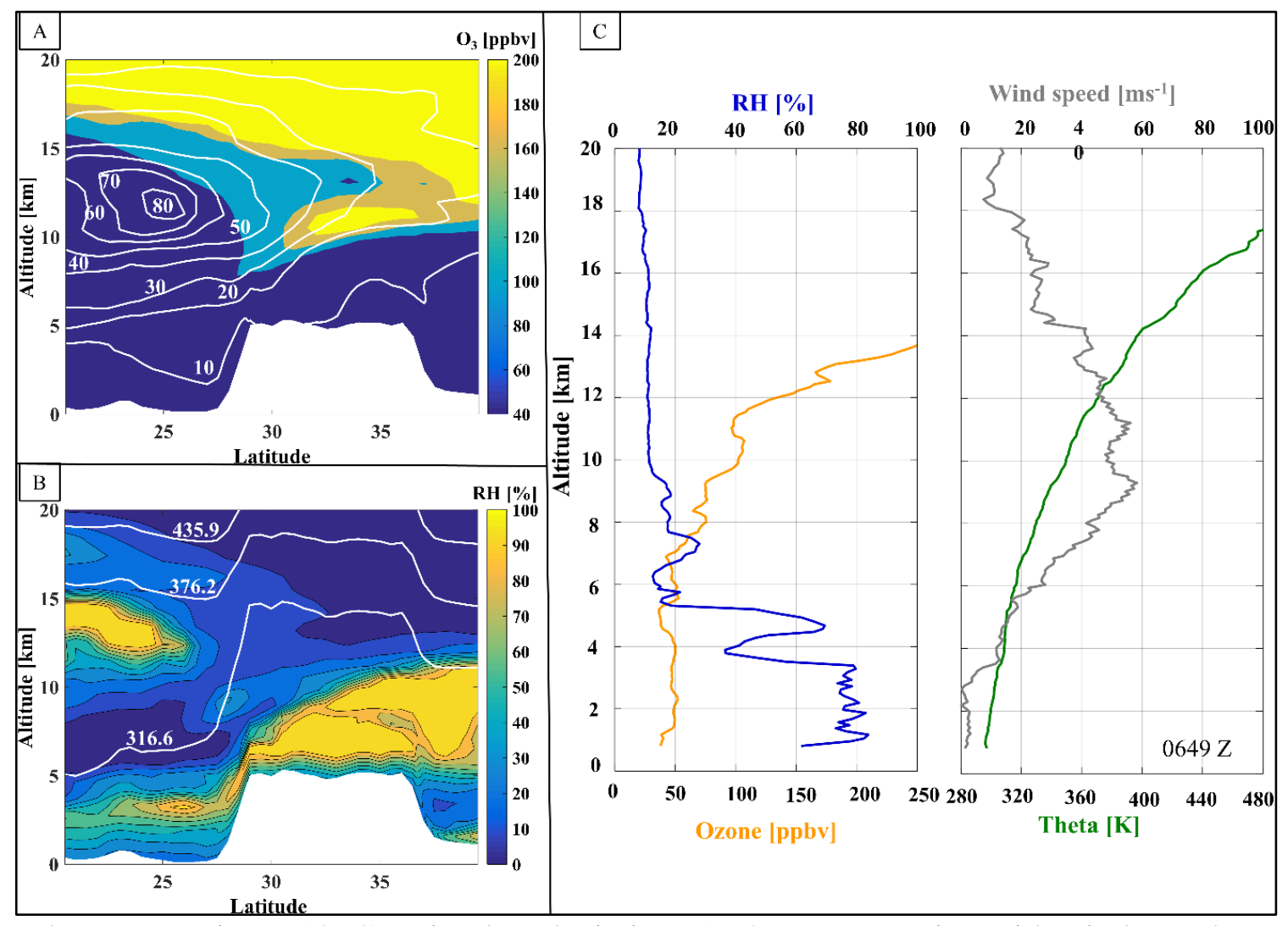

Supplementary Figure 13. Curtain plots depicting (A) $\mathrm{O}_{3}$ concentration with wind speed contours and (B) RH with theta contours predicted by MERRA-2 at $0600 \mathrm{Z}$ on 8 January 2016 and the corresponding vertical profiles of (C) $\mathrm{O}_{3}$ and $\mathrm{RH}$ and (D) wind speed and theta measured in situ on the same day with ozonesondes (Flight 36 in Supplementary Table 1). 


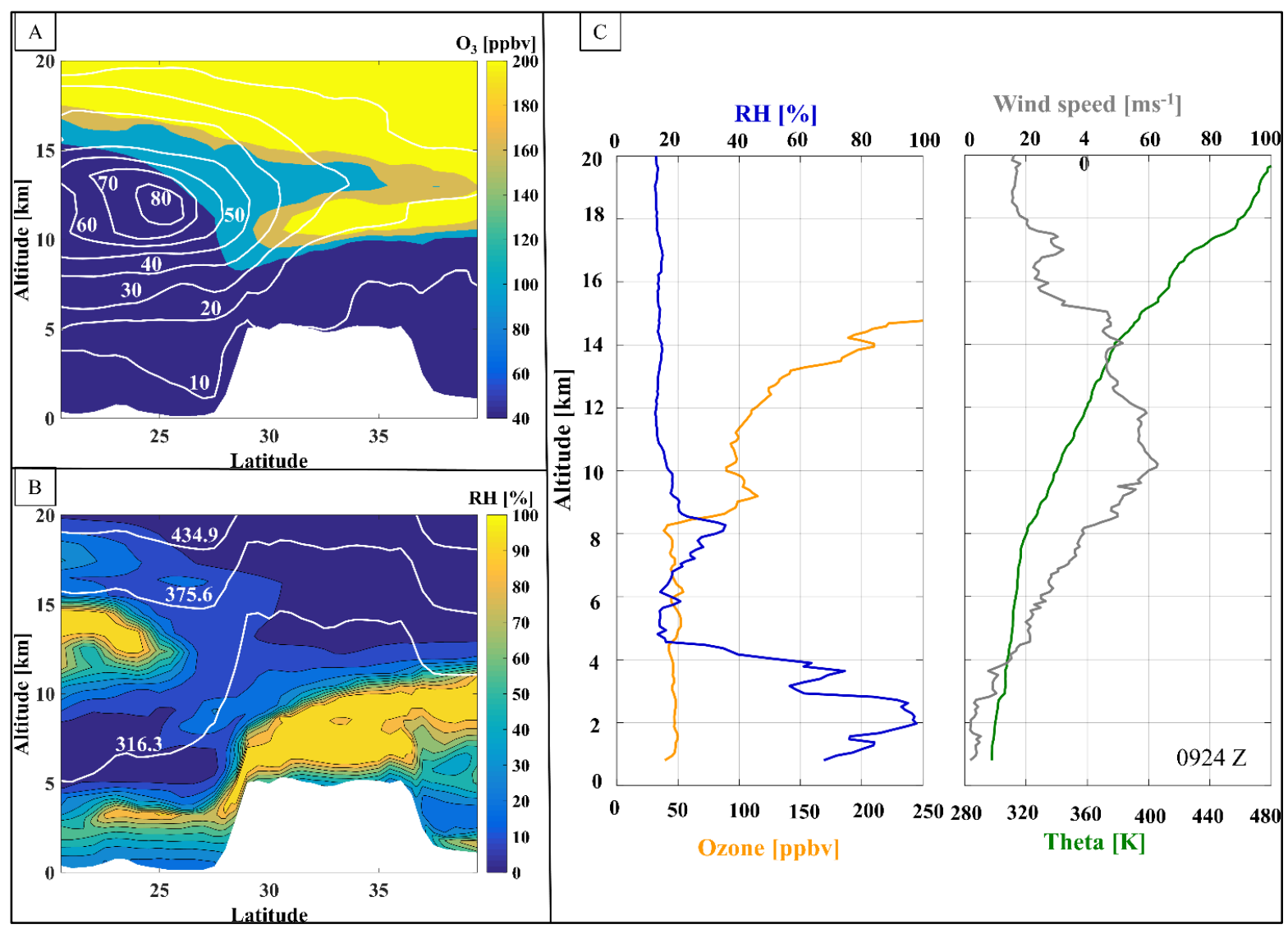

Supplementary Figure 14. Curtain plots depicting (A) $\mathrm{O}_{3}$ concentration with wind speed contours and (B) RH with theta contours predicted by MERRA-2 at $0900 \mathrm{Z}$ on 8 January 2016 and the corresponding vertical profiles of (C) $\mathrm{O}_{3}$ and $\mathrm{RH}$ and (D) wind speed and theta measured in situ on the same day with ozonesondes (Flight 37 in Supplementary Table 1). 


\section{CHAPTER 5. CONCLUSION}

The research reported in this dissertation provides new and important insight regarding processes by which $\mathrm{O}_{3}$ and $\mathrm{BC}$ are introduced to the Himalayan region. First, I found that emissions from the IGP are transported to the mouth of the Himalayan foothills by the synoptic weather systems and were subsequently transported up the valleys by the local wind system. The local wind system consisted of rapid up-valley flow during daytime and relatively slow down-valley flow at night. This pattern persisted throughout the year but the highest velocities and most efficient transport occurred during dry seasons. BC concentrations peaked in the morning and afternoon whereas $\mathrm{O}_{3}$ peaked only in the afternoon. Local emissions from combustion sources within the valley under relatively low wind conditions probably contribute to the early morning peak in BC. The afternoon peaks in both $\mathrm{BC}$ and $\mathrm{O}_{3}$ in conjunction with high up-valley wind velocities likely reflect broader regional patterns in pollutants transported from the IGP. Concentrations of BC and $\mathrm{O}_{3}$ varied seasonally with the highest concentrations during pre-monsoon season (March to June). Chemical constituents were transported up the valley during the day and down the valley at night. Due in part to this oscillatory flow pattern, BC mean concentrations within the valley did not differ significantly between day and night. However, during all seasons, the velocity and duration of up-valley winds and, thus the associated flux of BC, during the daytime were greater than those at night yielding a significant net BC flux up valley throughout the year. Based on a conservative estimate, the net up-valley flux of BC through a cross section of the valley at Jomsom during the pre-monsoon season was $1.2 \mathrm{~kg} \mathrm{day}^{-1}$. Multi-day periods during which BC concentrations within the valley were greater than the $90^{\text {th }}$ percentile for the year were characterized as regional transport episodes. These episodes occurred primarily during late spring and early fall and, based on back trajectories and satellite imagery, were attributed primarily to emissions from crop residue burning. Lastly, when we compared $\mathrm{BC}$ and $\mathrm{O}_{3}$ concentrations measured within the $\mathrm{KGV}$ with measurements a high elevation site at the base of Mount Everest. BC concentrations within the $\mathrm{KGV}$ were consistently higher by factors of 2 to 5 whereas $\mathrm{O}_{3}$ concentrations were consistently lower by a factor of 1.5 . These differences are driven in part by relatively greater contributions of stratospheric $\mathrm{O}_{3}$ at the higher elevation. Vertical profiles of $\mathrm{O}_{3}$ over the Himalaya coupled with tracers of stratospheric air including high PV values (greater than1.5 PVU), low RH (less than 20\%) and high theta (greater than $320 \mathrm{~K}$ ) 
revealed significant stratospheric contributions to tropospheric $\mathrm{O}_{3}$. Maps of PV anomalies at 250 hPa were constructed from MERRA-2 reanalysis data. Profiles of $\mathrm{O}_{3}$ and related meteorological parameters were then partitioned into two groups based on PV at the time of the launch (greater than or less than 1.5 PVU). During periods of high PV, median $\mathrm{O}_{3}$ concentrations between 9 and $13 \mathrm{~km}$ were 10 to 20 ppbv higher than those during low PV conditions. Profiles were also partitioned into two groups based on the transport path of sondes (over the Himalaya versus south of the range). Relative to air over the Himalaya, median $\mathrm{O}_{3}$ concentrations at 6 to $10 \mathrm{~km}$ altitude, in air south of the Himalaya were approximately $10 \mathrm{ppbv}$ higher. The findings show frequent influences of stratospheric air masses near the Himalaya. This can possibly be a result of active tropopause folding over the Himalaya as well as advection or subsidence of stratospheric air masses upwind the Himalayan region. PV based back-trajectories would help inform paths of transport from the stratosphere and the location of transport. In addition, studies designed to measure $\mathrm{O}_{3}$ along with $\mathrm{O}_{3}$ precursors like nitrogen oxides throughout the year would be helpful in understanding the roles of surface based $\mathrm{O}_{3}$ enhancements.

Profiles measured with ozonesondes were interpreted in conjunction with MERRA-2 reanalysis data (wind speed, theta, $\mathrm{RH}$ and $\mathrm{O}_{3}$ ) to evaluate processes that modulate tropospheric $\mathrm{O}_{3}$ over the Himalaya. The complex topography formed by the Himalaya ranges and the Tibetan Plateau caused an upwelling of isentropic surfaces above this cold, high-elevation region. The upwelling created a strong potential temperature gradient along the southern slopes of the Himalaya, which facilitated isentropic transport of stratospheric air along these surfaces into the troposphere. However, the degree of influence was varied substantially based on the position of the SJS core (or cores) with respect to the thermal gradient. When the core(s) of the SJS was (were) south of the thermal gradient, we hypothesize that the stratospheric air was transported down from the northern edge of the SJS along the isentropic surface south of the Himalaya. When the core of the SJS was above or south of the thermal gradient, $\mathrm{O}_{3}$ concentrations above 8 to $10 \mathrm{~km}$ altitude were consistently higher by 10 to 20 ppbv relative to mean values. We also frequently observed intermixed layers of air with distinct PV values in conjunction with multiple chemical, dynamical and thermal tropopauses, which suggests both stratospheric and tropospheric origins and implies that transport along the tropopause is diffusive in nature. 
In summary, this dissertation fills important gaps in our understanding of processes that modulate $\mathrm{BC}$ and $\mathrm{O} 3$ cycling in the Himalaya region. Results confirmed the hypothesis that local wind systems within deep trans-Himalayan valleys are important pathways by which pollutants are transported from the IGP to the high Himalaya and TP. The first quantitative estimates of BC fluxes and seasonal variability in those fluxes through the KGV are reported. This research also demonstrated that STE events contribute significantly to tropospheric $\mathrm{O}_{3}$ in the region and identified major dynamic and topographic factors that modulate exchange. However, additional studies are needed to quantify fluxes of pollutants other than $\mathrm{BC}$ through the $\mathrm{KGV}$ and to characterize magnitude and nature of pollutant transport through other trans-Himalayan valleys. In-situ measurements nitrogen oxides, hydrocarbons, and $\mathrm{CO}$ in conjunction $\mathrm{O}_{3}$ and meteorological conditions within Himalayan valleys in parallel with concurrent sonde-based measurements of $\mathrm{O}_{3}$ and meteorological conditions through the overlying atmosphere would also help deconvolute relative influences of regional emissions versus transport from the stratosphere on vertical profile of $\mathrm{O}_{3}$. This work yielded a new and broadly applicable set of measurements for key short-lived climate pollutants in a data sparse region of the world. 
